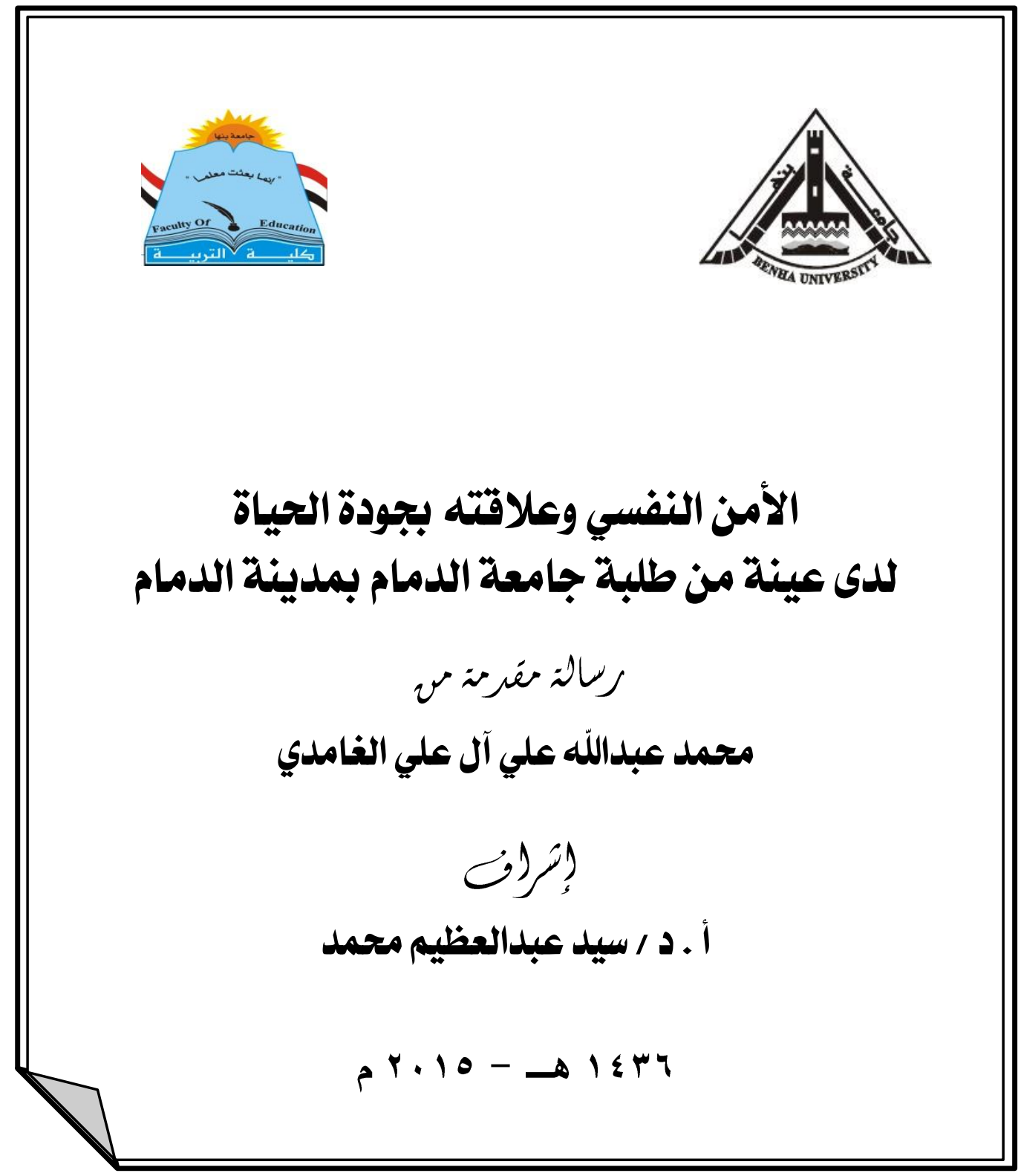




\title{
الأمن النفسي وعلاقته بجودة الحياة \\ للى عينة من طلبة جامعة الدمام بمدينة الدمام
}

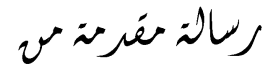

محمد عبدالله علي آل علي الغامدي

(2)

أ ـ د / سيد عبدالعظييم محمد

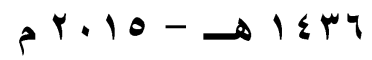

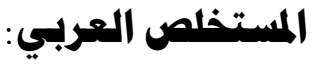

تم دراسة الأمن النفسي وعلاقته بجودة الحياة لدى عينة من طلبة كلية التربية بمدينة الدمام ، وهدفت الدراسة إلى التعرف على مستوى الامن النفسي لاى عينة من كلية

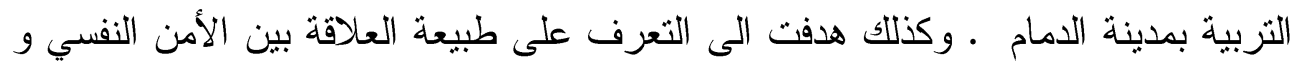

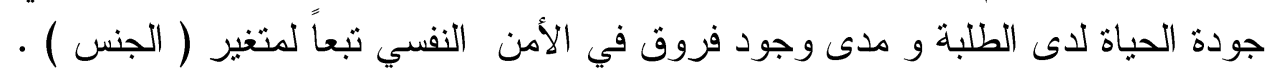

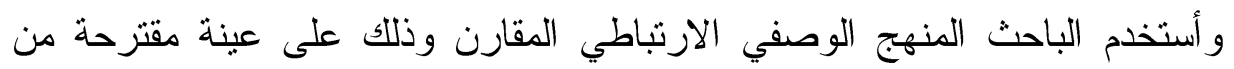

( . ( ) طالب وطالبة بكلية التربية بجامعة الدمام.

و نت صباغة فروض الدراسة على النحو التالي:

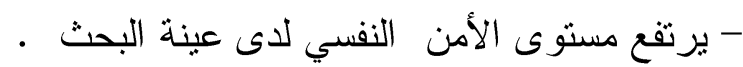

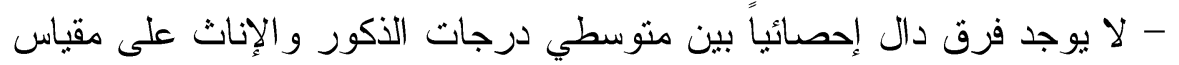
الأمن النفسي لصالح الأكور •

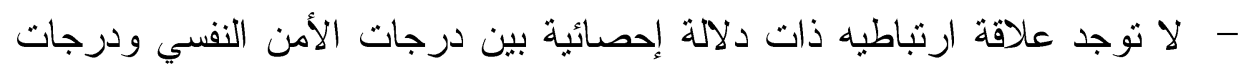

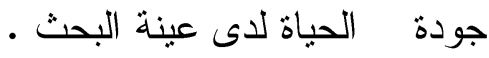

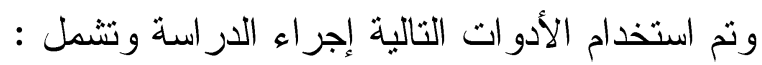

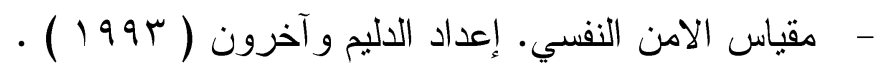

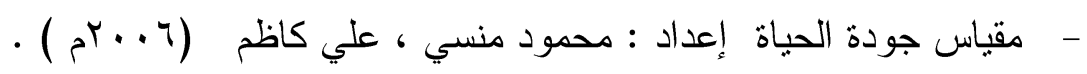




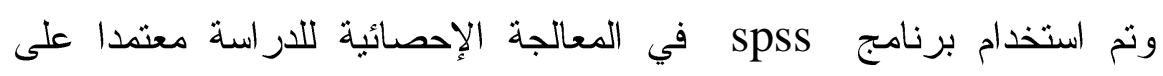

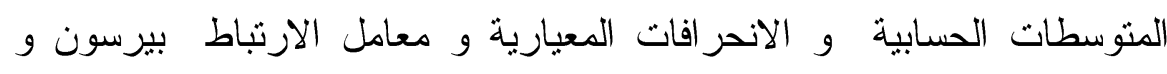
اختبار (ت) (تو (ت)

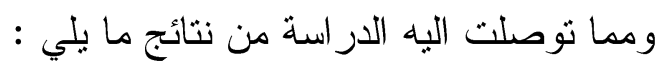

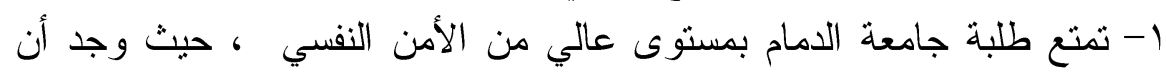

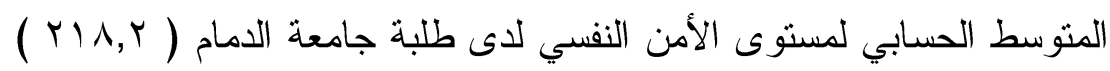
، وهذه الدرجة أعلى من المتوسط الحسابي الفرضي لمقياس الأمن النفسي لألفي

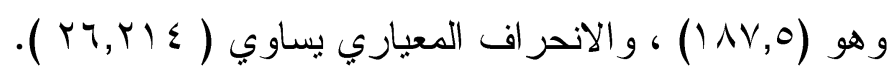
Y- يوجد هنالك فروق ذات دلالة إحصائية بين متوسطي درجات الذكور و الإناث

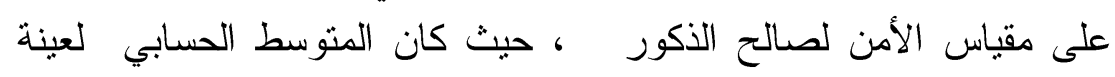

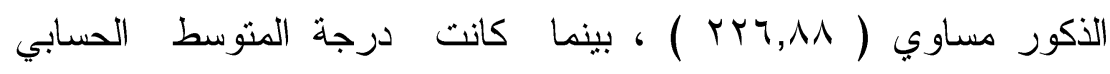

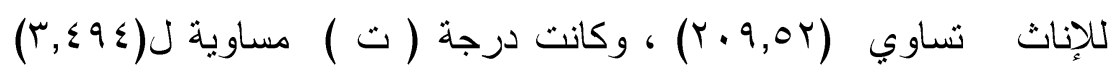

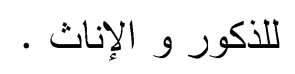
r- وجود علاقة ارتباط ذات دلالة إحصائية بين مستوى الأمن النفسي ومستوى الأنى

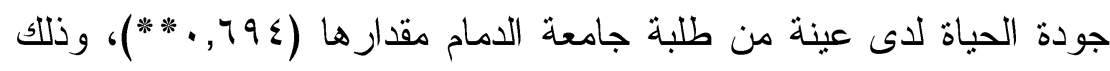

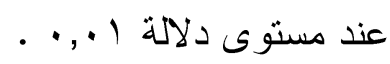




\section{النصل الأول \\ هدخل إلى الدراسة}

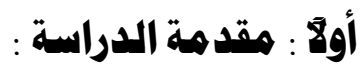

يمتاز العصر الحالي بالتطور المتسارع في شتى المجالات و على كافة الأصعدة إلا أنه

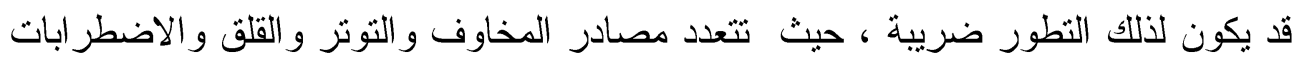

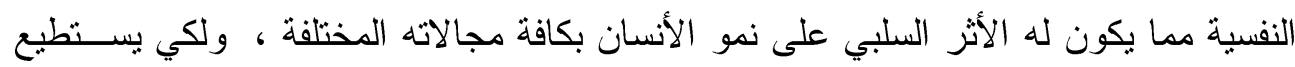

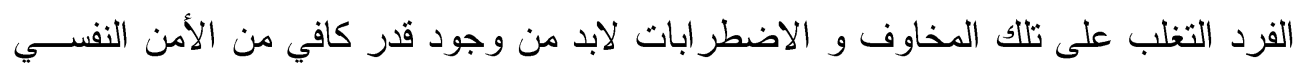

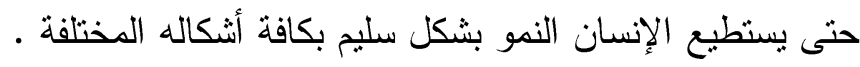
ويؤكد ذلك ( Fatil , 1985 ) حيث يرى أن عدم الشعور بالأمن النفسي يؤثر على النمو

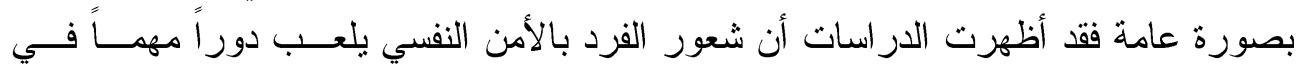

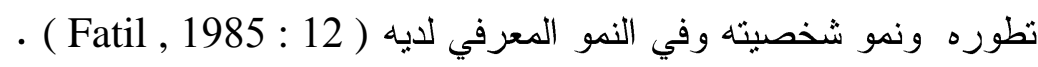

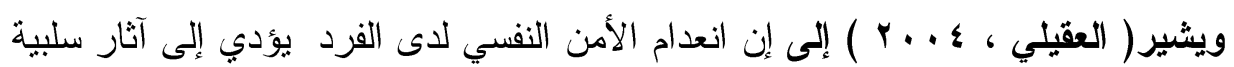

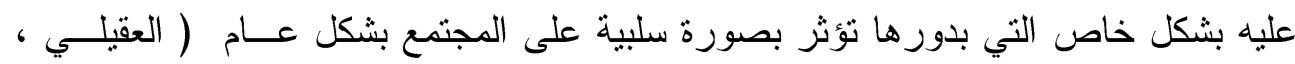
. (r: r. .

ويؤكد ( لبيب ، . 19VV) بدر استه أن انعدام الأمن يجعل الفرد يجد صعوبة في مواجهة

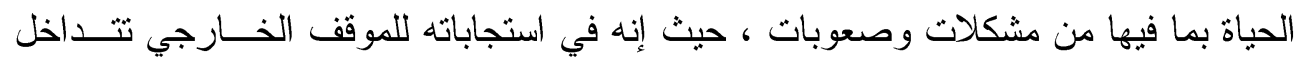

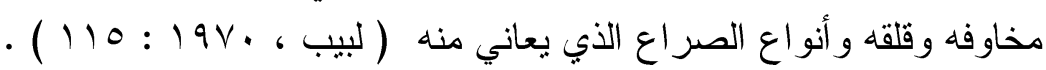

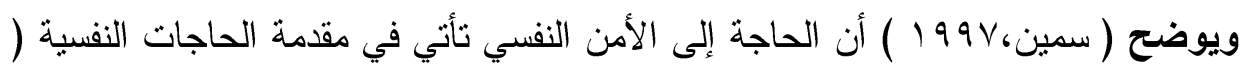

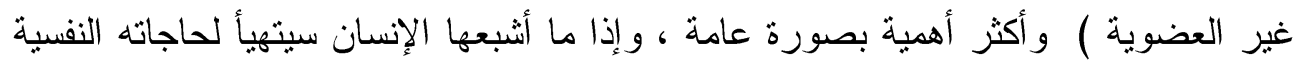

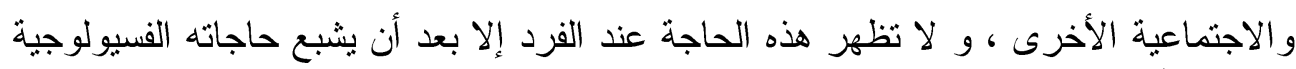

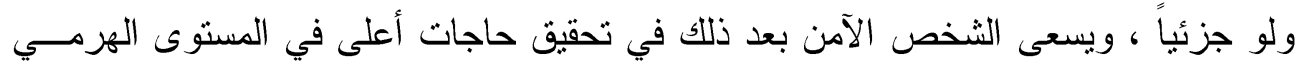

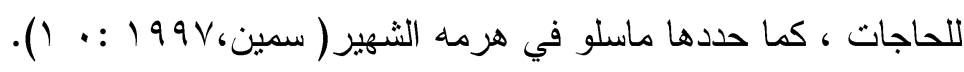

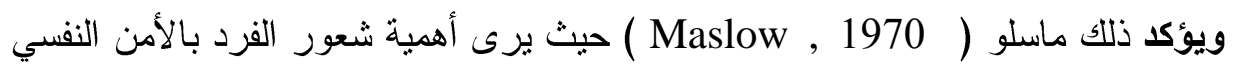

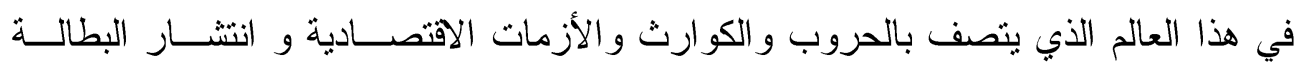

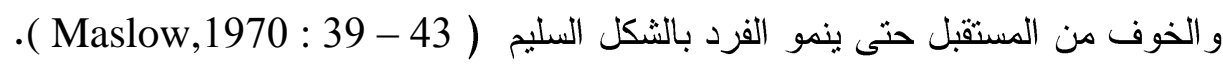

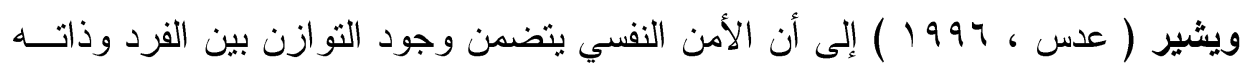

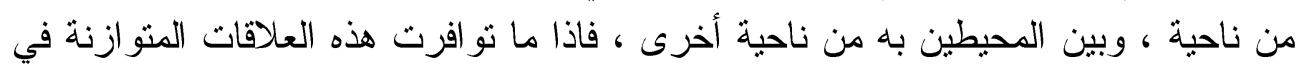

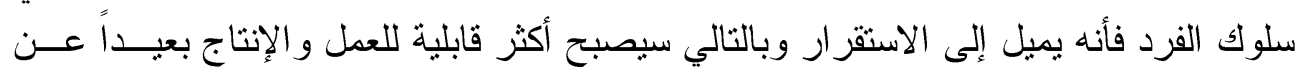

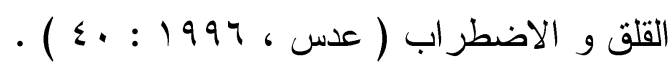
و الأمن النفسي مهم في إحداث النو افق النفسي و الاجتماعي 
حيث أثثارت نتائج در اسة ( بشير ، 9 . . ب ) إلى وجود علاقة بـين الأمسـن النفسـي

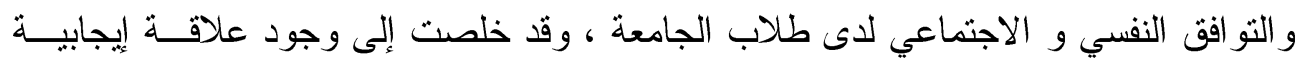

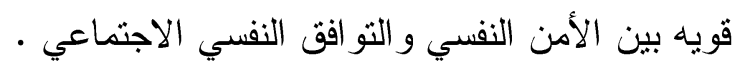
وقد يكون من أهم مسببات شعور الفرد بالأمن النفسي هو التمسكي الفك بتعاليم الدين القويم

لذا أهتم كثير من الباحثين بدر اسة الأمن النفسي وعلاقته بالسلوك الديني مثــل الإيمـــان

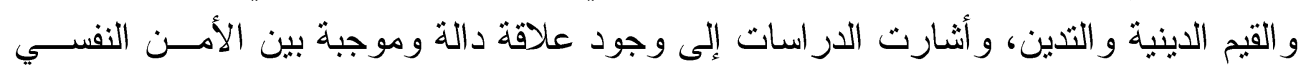

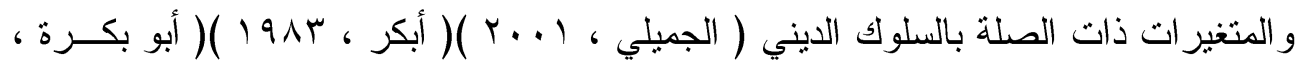
. (1994

ومما لاشك فيه أن الفرد الذي يتمتع بمستوى عالٍ من الأمن النفسي قد يستطيع مواجهة

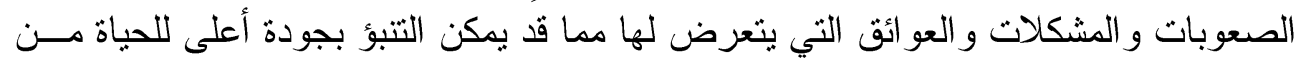

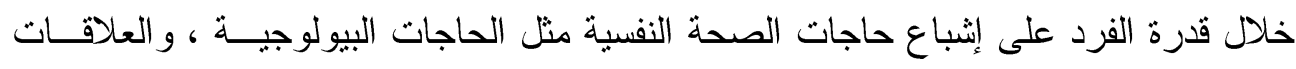

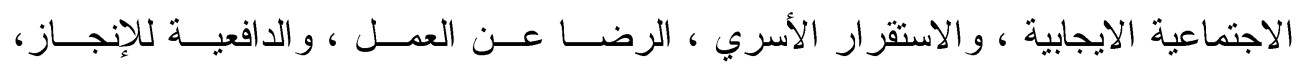

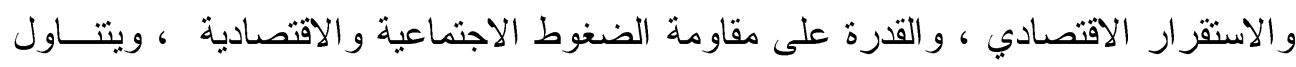

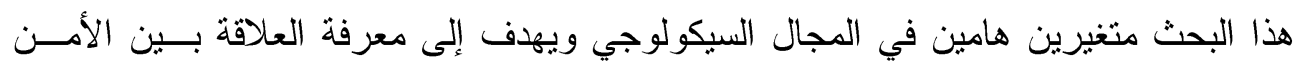

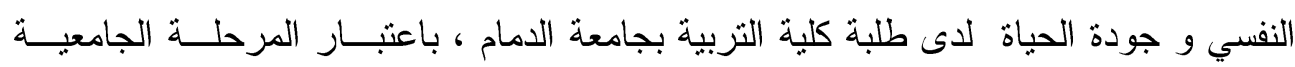

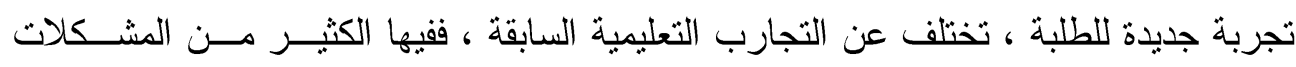

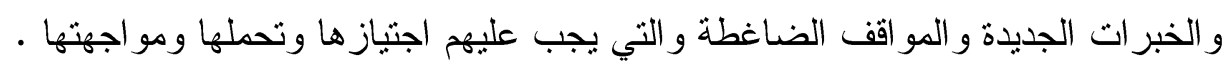

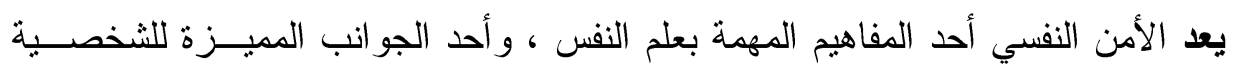

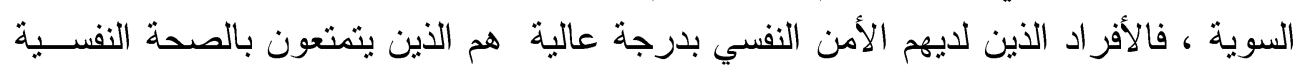

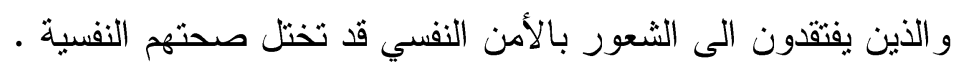

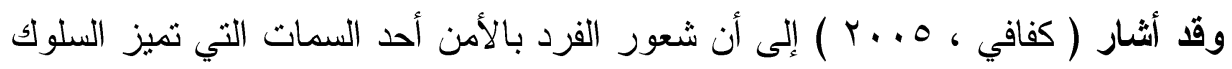

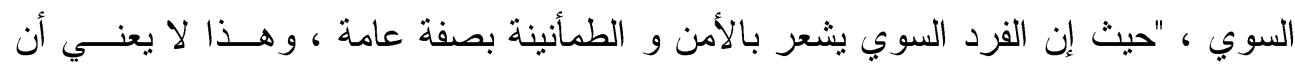

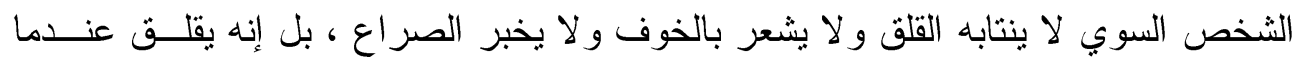

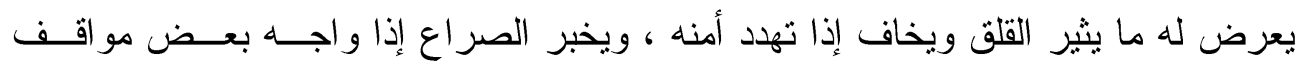

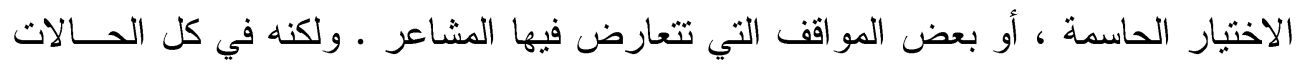

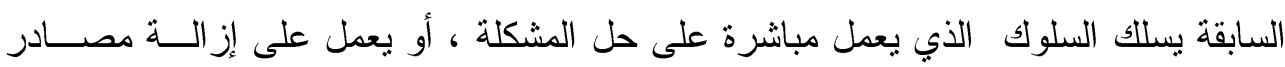

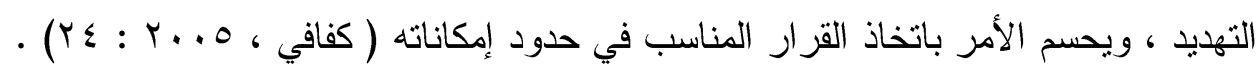


ولا يتوقف تأثثر الأمن النفسي على النواحي الانفعالية للفرد بل قد يمتـد إلـى حياتـهـ الدر اسية أيضاً التئ.

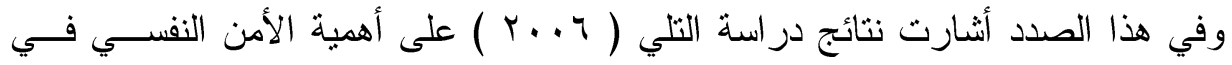

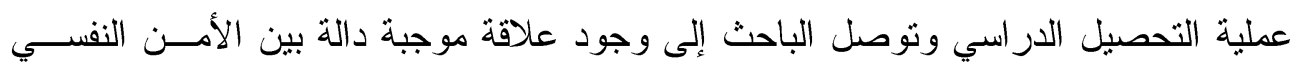

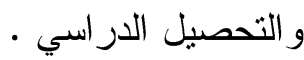
بل أن انعدام الأمن النفسي يودي إلى ظهور بعض الاضطر ابات و الأمر اض النفسية مثــلـ الخوف و القلق و الاكنئاب. حيث أكلات نتائج در اسة (Ropet\&Jone , 1996 أن النعدام الأمن قد يؤدي إلى ظهور

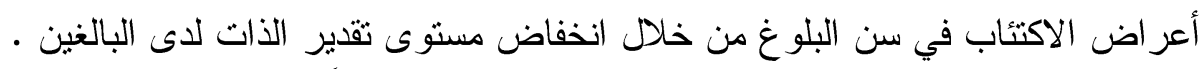

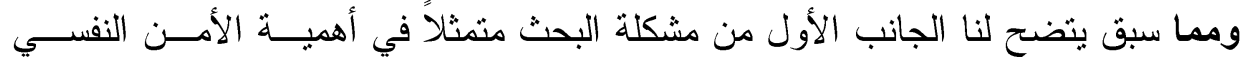

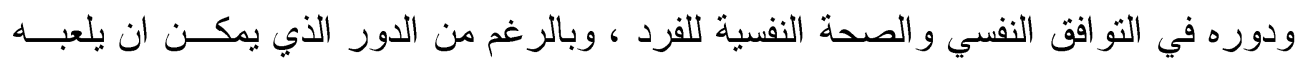

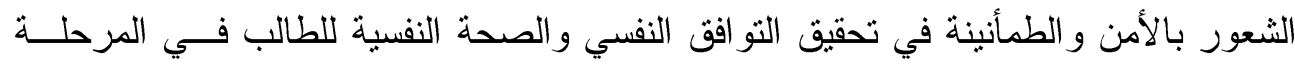

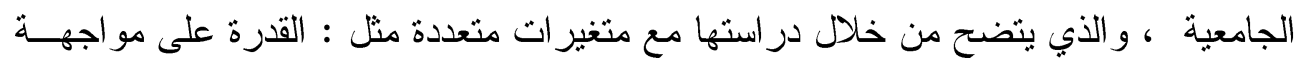

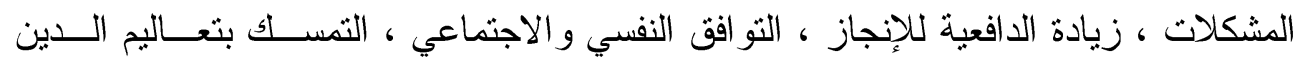

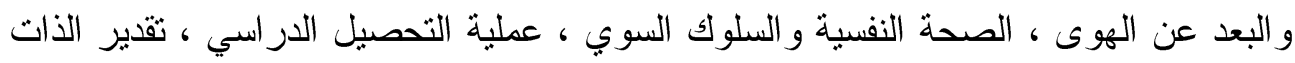

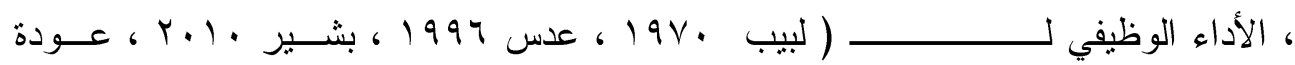

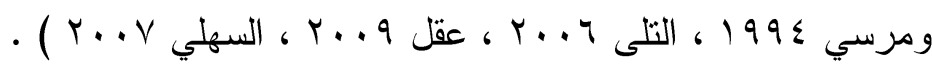

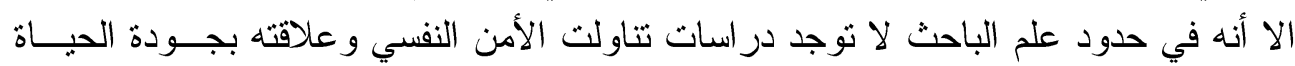

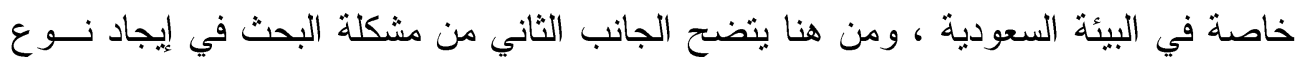

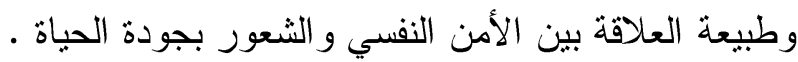

ومما سبق ثثير مشكلة الدر اسة ، التساؤلات التالية :

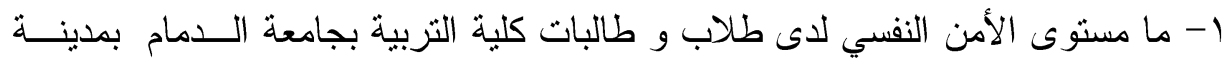

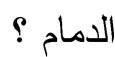
ץ- ما مستوى جودة الحياة لدى طلاب وطالبات كلية التزبية بجامعة الدمام بمدينة الدمام ? ץ- ما طبيعة العلاقة بين الأمن النفسي وجودة الحياة لدى عينة البحث ؟ ع - هل يختلف الذكور عن الإناث في الأمن النفسي ؟ 
1- لها أهمية في الدور الذي يقوم به الأمن النفسي في تحقيق التكيف و التو افق النفسـي التهي

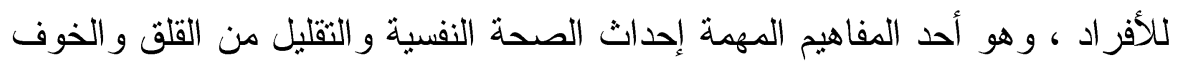

$$
\text { و الثونز }
$$

r- لها دور في إضافة نتاج جديد إلى التر اكم المعرفي حول العلاقة بين الأمن النفسـي

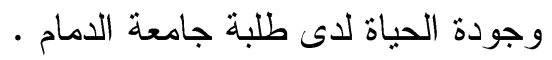

ب- توفير المعلومات الهامة التي يحتاجها أصحاب القرار و المهتمين بالتطوير في جامعة التماء - الدمام

ع - توفير بعض الحلول للمشكلات التي قد نواجه طلبة جامعة الدمام وتزويد الجامعـة ببعض التوصيات المتعلقة بالدر اسة التهن

0- الاستفادة من نتائج الدر اسة في تحسين مستوى الأمن النفسي وجودة الأنة الحياة .

\section{رابها : أهداف الدراسة :}

تسعى الدراسة الحالية إلى محاولة التحقق من الأهداف التالية :

1- تعرف مستوى الأمن النفسي وجودة الحياة لدى كل من الذكور و الإناث بكليــة التزبيـــة

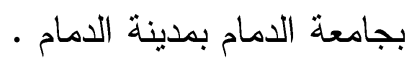

r- تعرف العلاقة بين الأمن النفسي و جودة الحياة لدى عينة البحث.

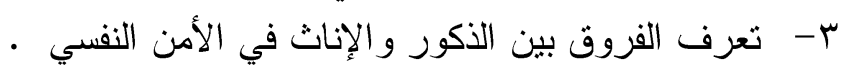

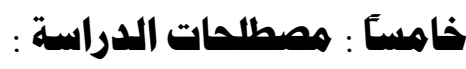

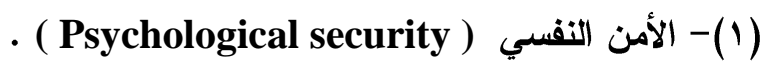
ا - التعريف اللغوي النفين

(أمن) - أمنا ، وأماناً ، و أمانة ، ومناً ، و وإمناً ، و أمنةً : اطمأن ولم يخف ، فهو ، آمن ( أبــن

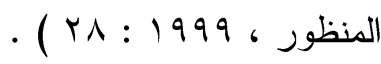

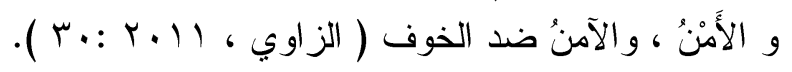

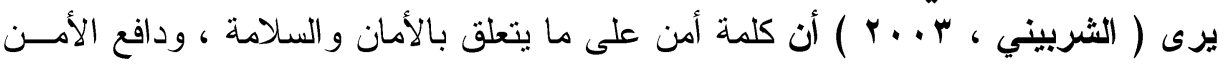

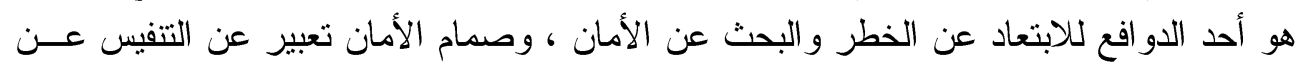

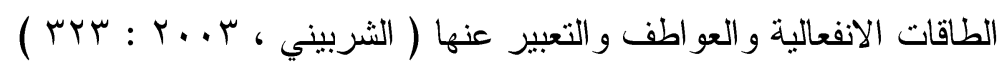

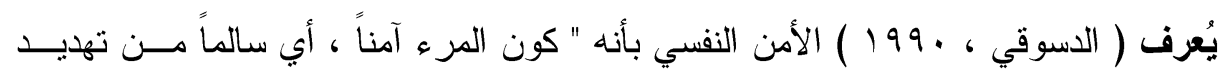

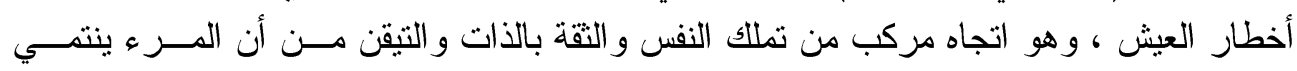




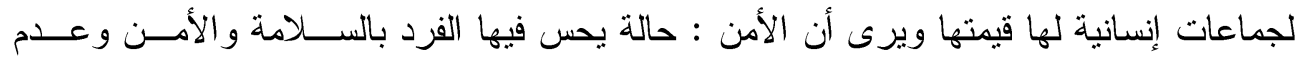

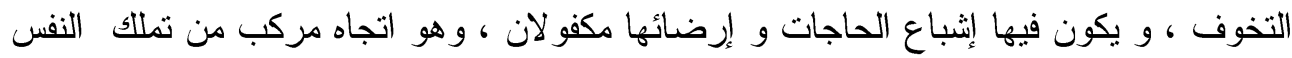

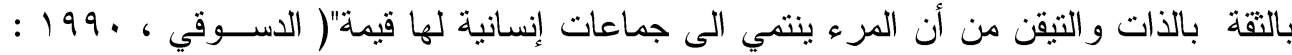
- (rrq

\section{r - التعريف النفسي ( السيكوالوجي ) .}

يعد مفهوم الأمن النفسي من المفاهيم العامة في مجال الصحة النفية النفية التي أختلف البـاحثين

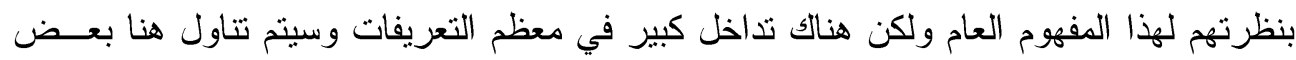

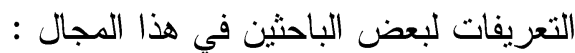

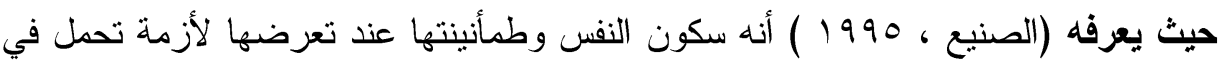

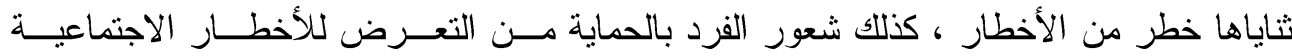

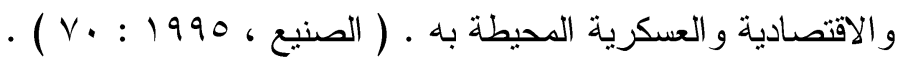

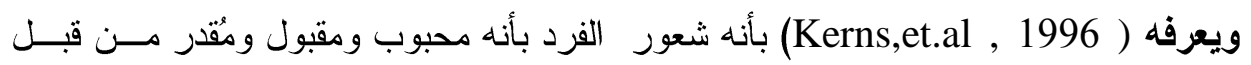

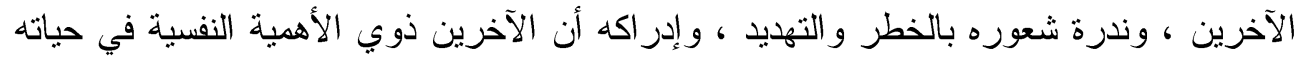

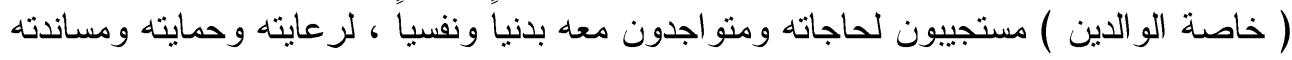

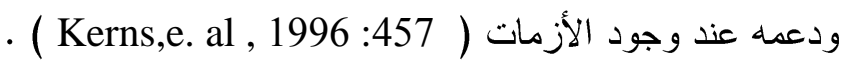

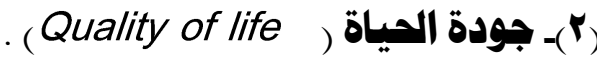
أ- التعريف اللغوي

يعرف "أبن منظور" في معجمه لسان العرب كلمة " الجودة " بأن أصلها (جود)

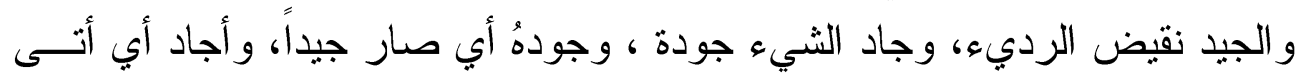

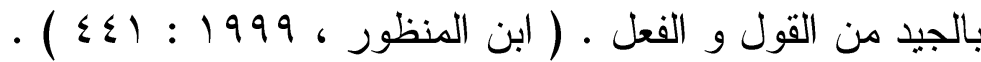
ب- التعريف القاموسي .

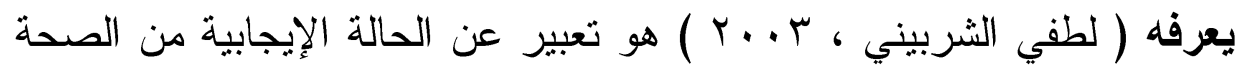

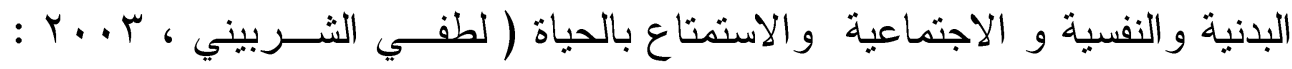
. (77

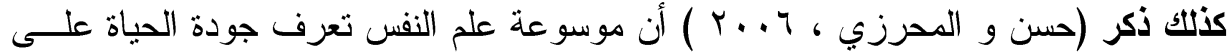

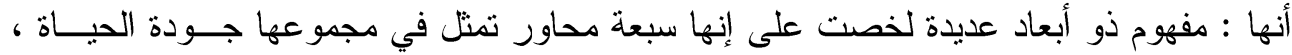

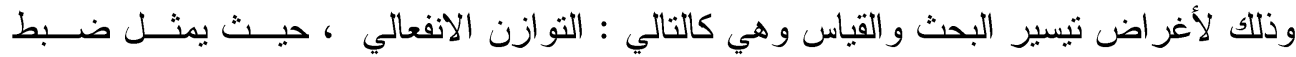




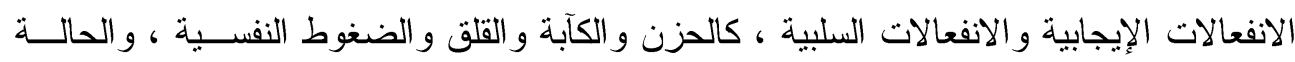

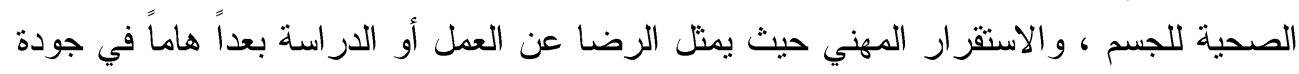

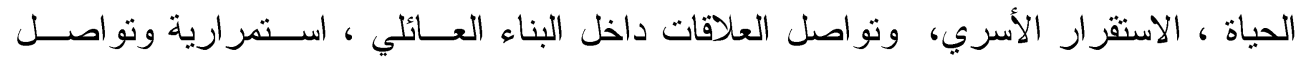

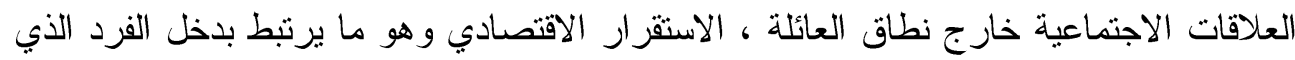

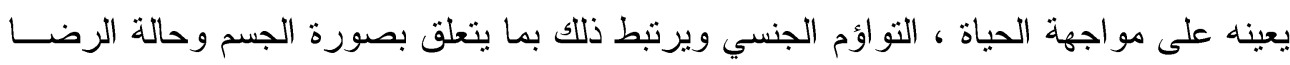

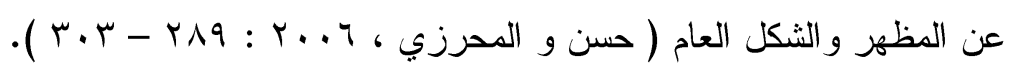

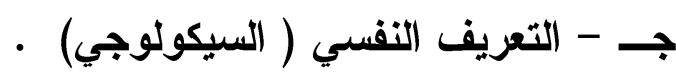

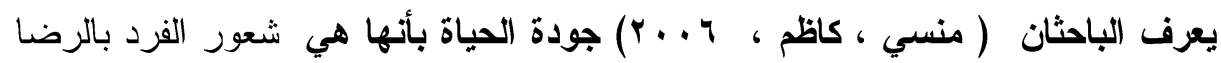

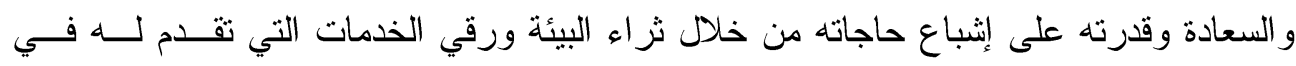

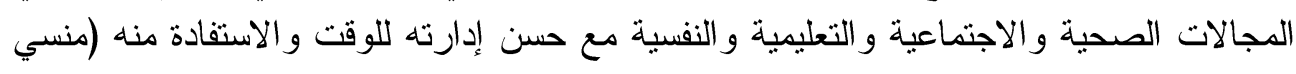

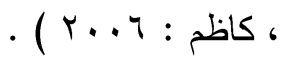

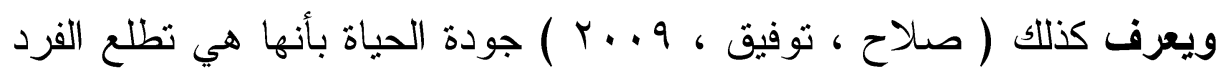

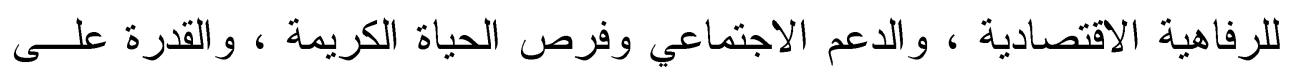

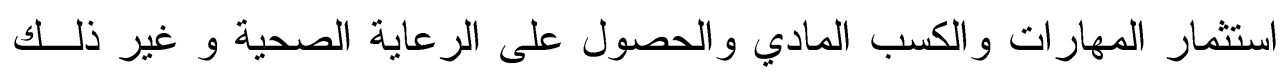

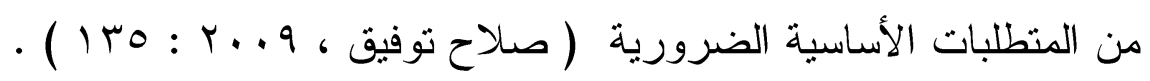

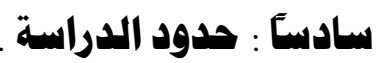

(1)- الحدود الزمانية : تتحدد بتاريخ التطبيق في الفصل الدراسي الثـاني للعــام الدراسـي . $1 \leqslant$ ـ (r)- الحدود المكانية : ستقتصر الدار اسة على عينة من طلبة كلية التربية بمدينة الدمام بالمملكة العربية السعودية

(r)- الحدود البشرية : تتحد الحدود البشرية بطلبة كلية التربية بمدينة الدمام (ذكور و إناث ) (؛)- الحدود الموضوعية: تتحد الحدود الموضو عية بمتغيري الامن النفسي و جودة الحئة الحياة.

ب- منهج البحث سيستخدم في الدراسة المنهج الوصفي الارنباطي المقارن •

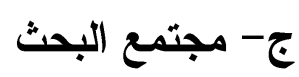
يتكون مجتمع الدارسة من عينة من طلبة كلية التربية بجامعة الدمام بمدينة الدمام بالمنطقة

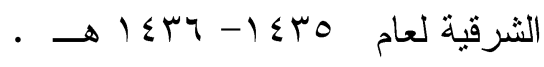




\section{د - عينة البحث}

سيتم اختيار عينة الدر اسة مقدارها ( . . () بطريقة عشو ائية من طلبة كلية التربية بجامعة

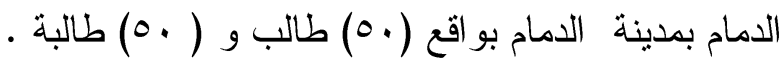

هـ- أدوات البحث

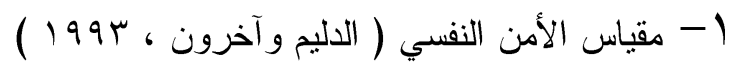

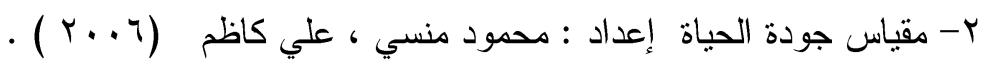

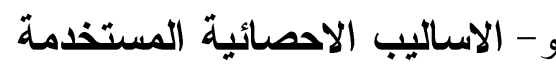

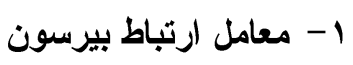

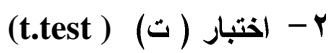

\section{النصل الثاني \\ ( الإطار النظري وهصطاحًات الدراسة )}

أولاً : الأمن النفسي :

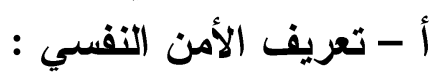

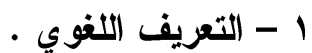

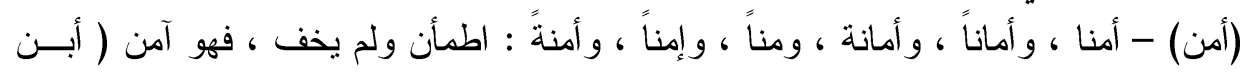

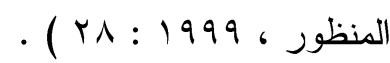

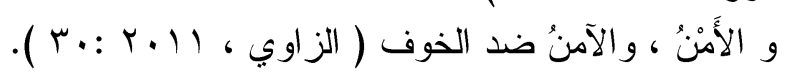

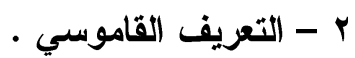

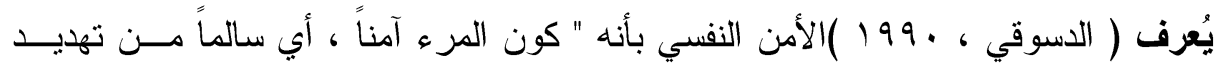

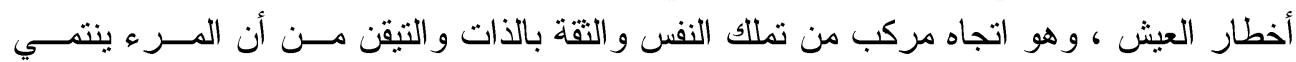

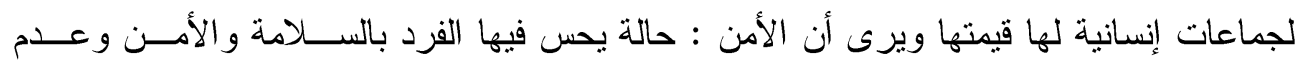

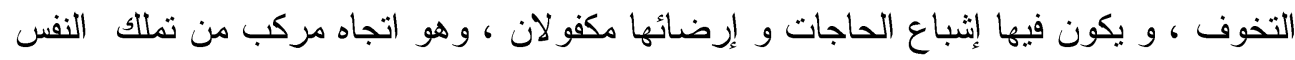

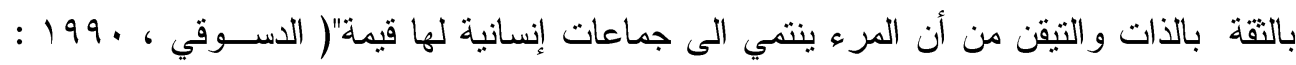

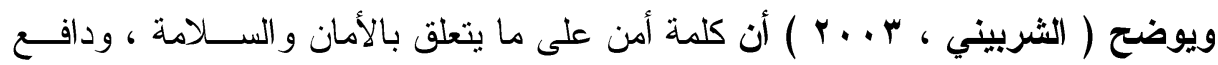

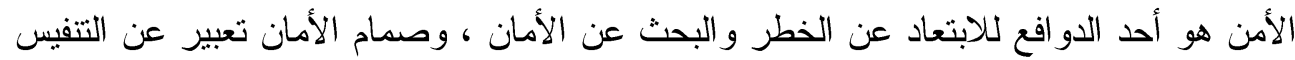

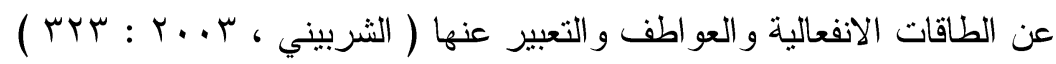

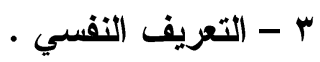


يعد مفهوم الأمن النفسي من المفاهيم العامة في مجال الصحة النفسية التي اختلف الباحثين

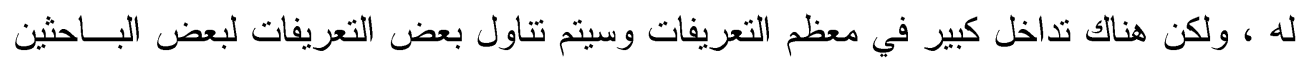
في هذا المجال :

حيث يشير (Londervill \& main, 1981) أن الأمن النفسي يعد من أهـــ الحاجـات

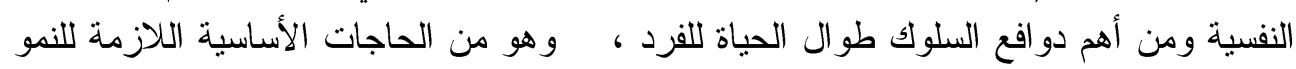

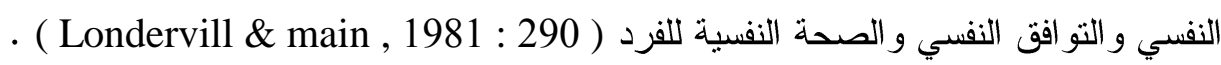

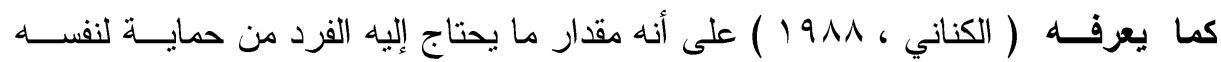

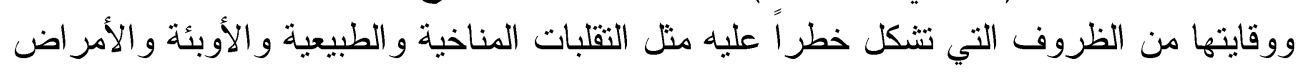

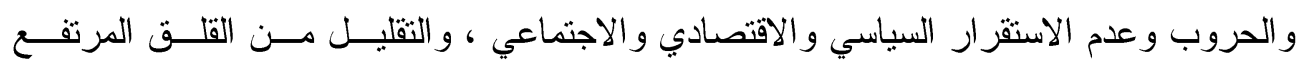

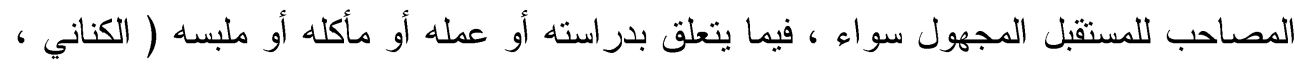
. (9r: 1911

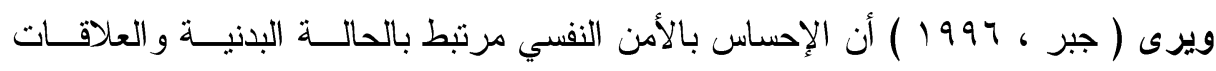

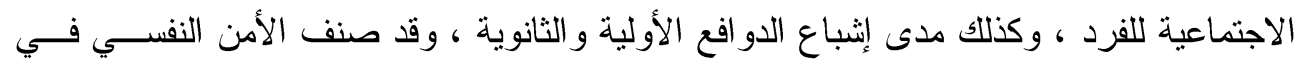

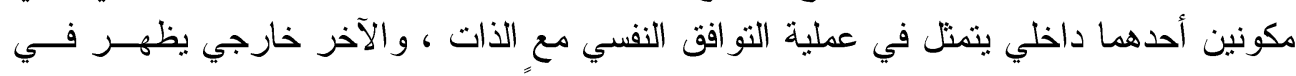

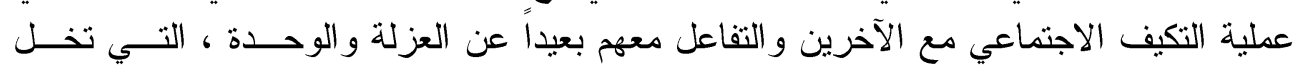

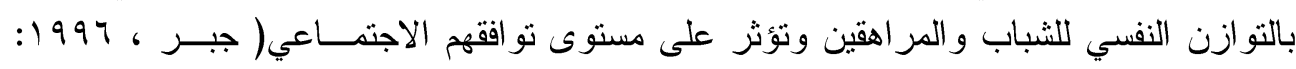
. (^. وكنللك عرف ( Kerns,et.al , 1996 ) الأمن النفسي هو شعور الفرد بأنه محبوب ومقبول

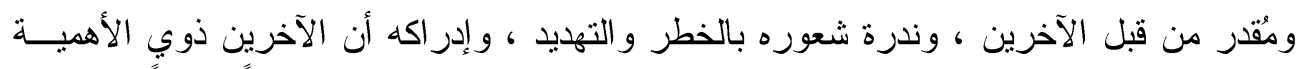

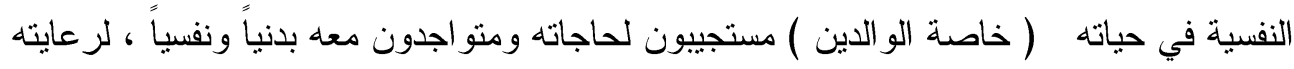

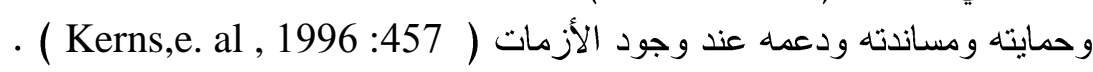

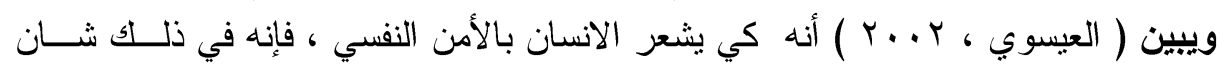

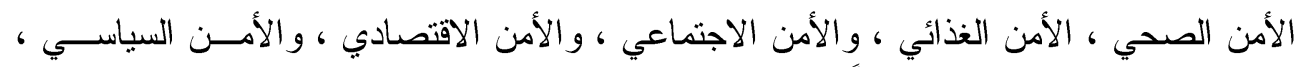

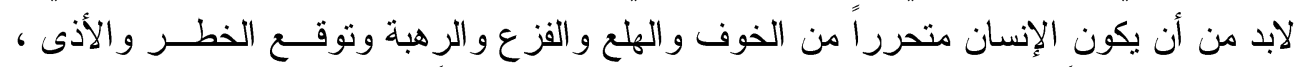

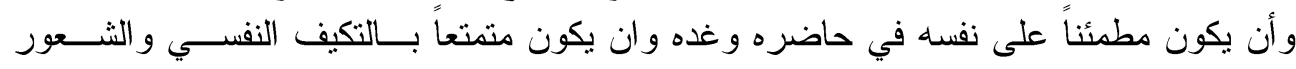

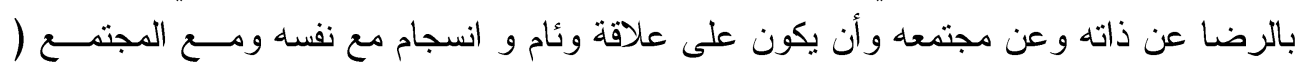

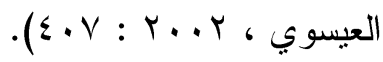

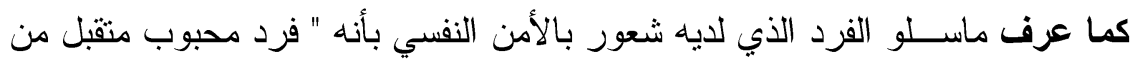

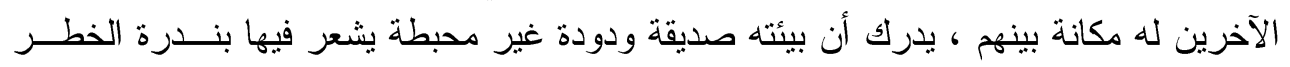

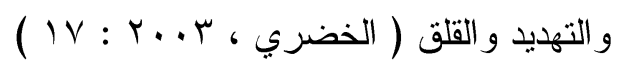




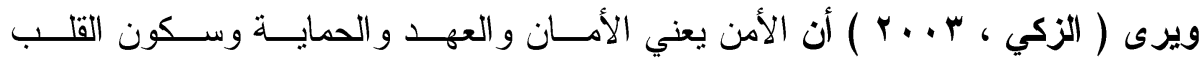

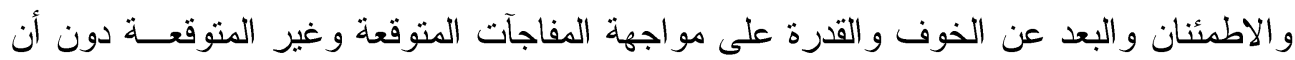

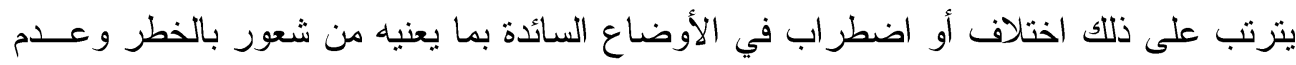

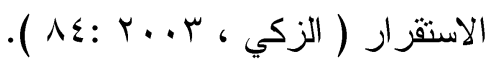

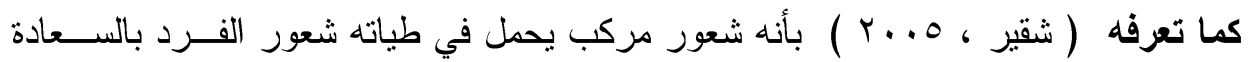

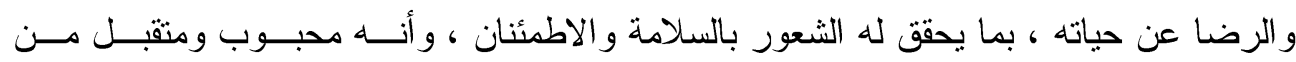

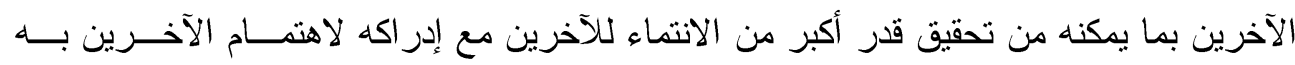

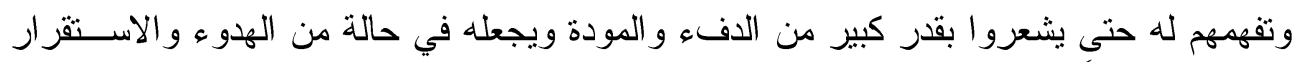

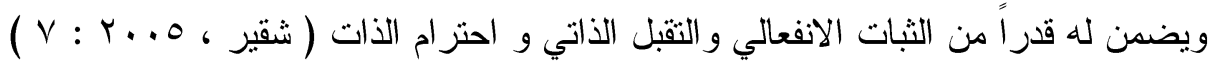

يتضح من التعريفات السابقة أن مفهوم الأمن النفسي مفهوم عــــام تختلف زاوية رؤية كل

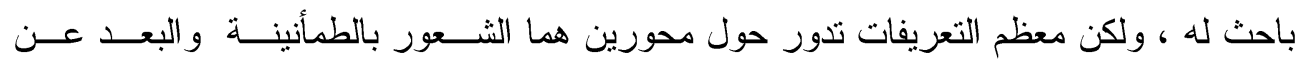

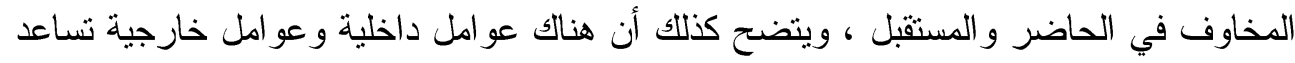
في وجود الأمن النفسي لدى الفرد ، ويعد الأمن النفسي من الحاجات الأساسية التي بسعى الأنس الأنسان

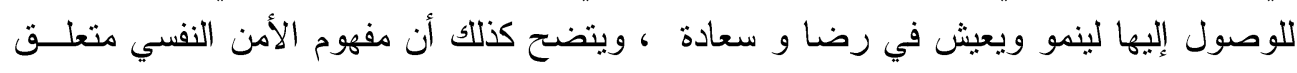

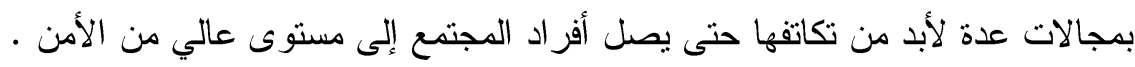

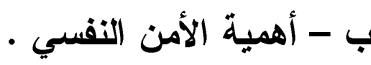

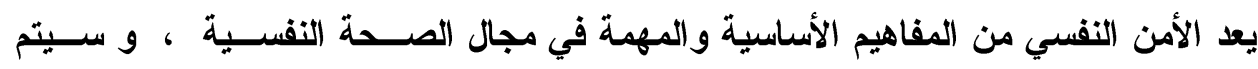
تناول أهميته في النقاط التالية : 1- الأمن النفسي له أهمية في نمو الفرد بالثية : بالثكل السليم بكافة أشكاله المختلفة .

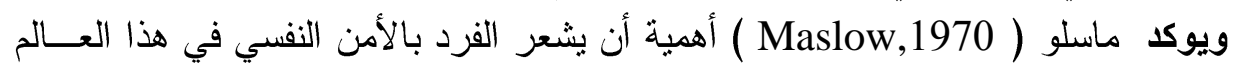

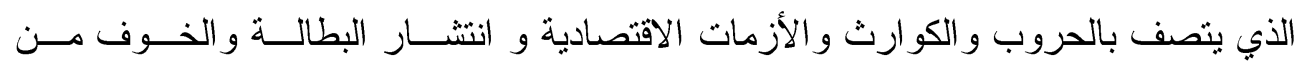

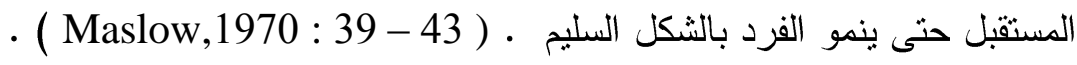
ويؤكد ذلك فاتل ( Fatil , 1985 ) حيث يرى أن عدم الثعور بالأمن النفسي يؤثر على الثى

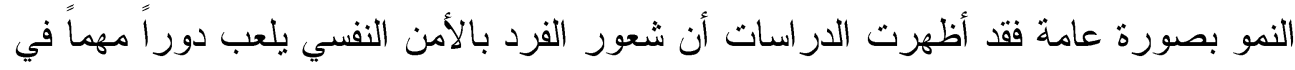

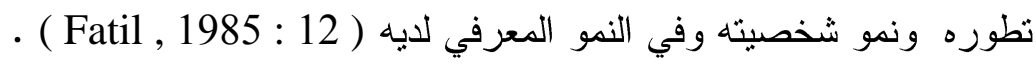

r- بعد الأمن النفسي ضروري لإحداث التو افق للفرد بكافة أنثاله المختلفة .

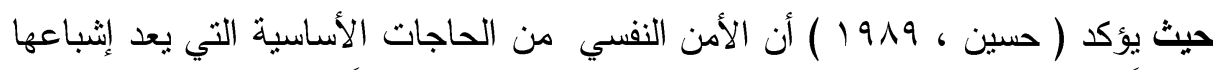

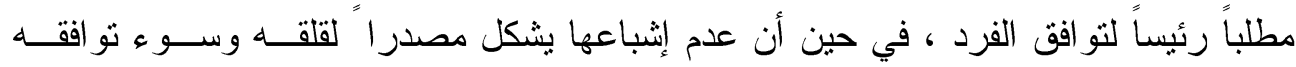

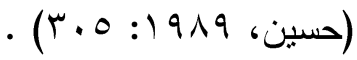




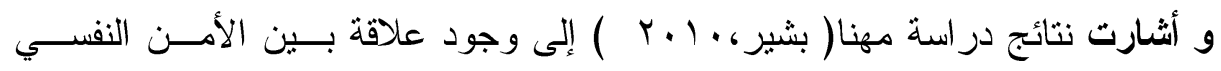

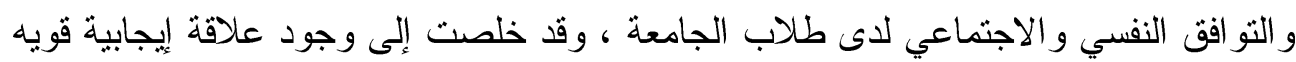

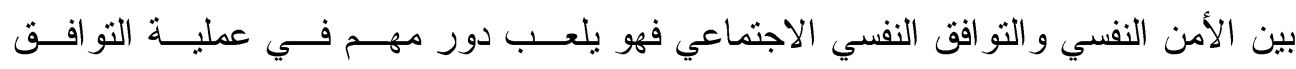
الاجنماعي.

ب- يعد الأمن النفسي مطلب أساسي لجميع الأفر اد ، و أحد الأهــــاف التــي يســى الفــرد لتحقبقها.

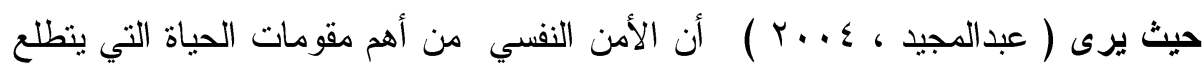

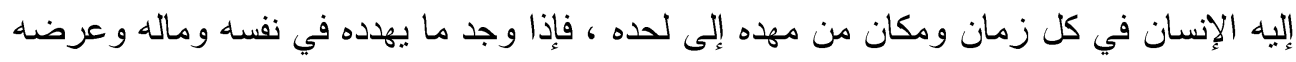

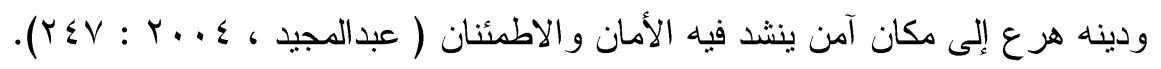

ع- الأمن النفسي ضروري لاستقرار المجتمع ، وسعادة أفراده .

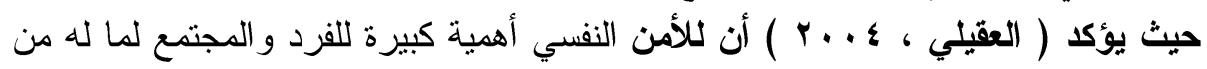

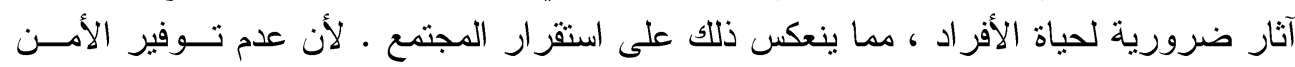

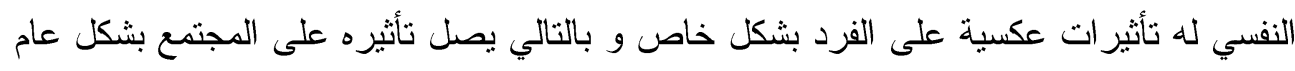

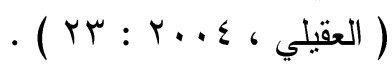

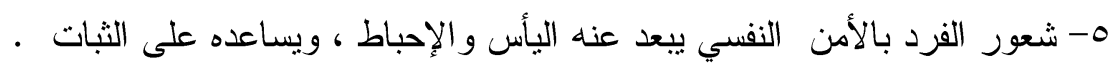

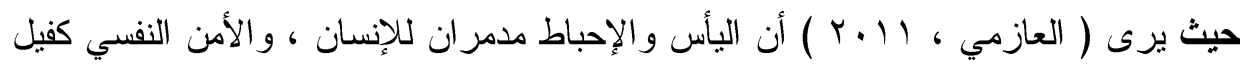

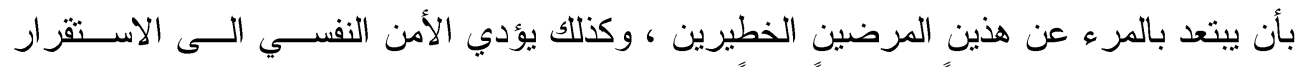

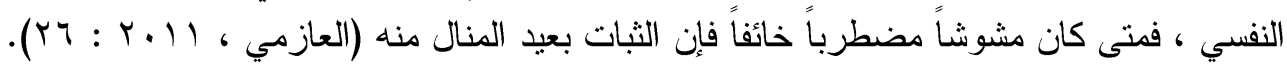

7 - يساعد الأمن النفسي على اكتمال الثخصية الإسلامية ، ويعطي ثقة كاملة بمعية الله ونصره.

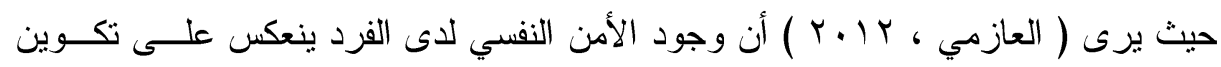

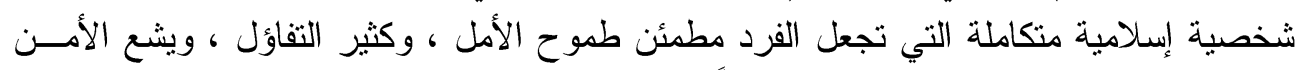

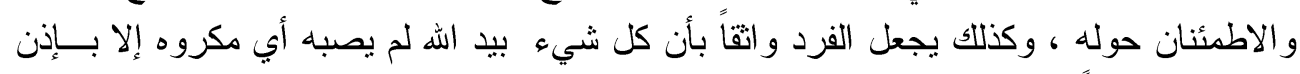

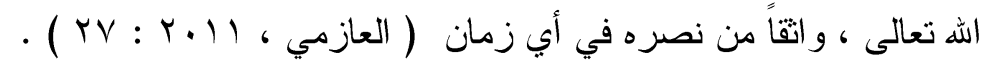

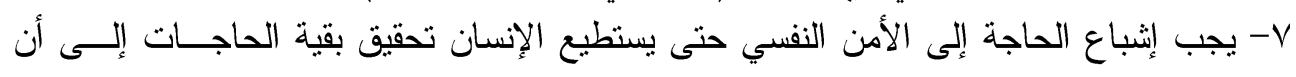

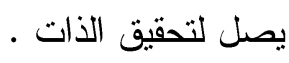

حيث يرى ( From , 1971 ) أن الحاجة إلى الأمن هي قاعدة الحاجات الإنسانية جميعـاً

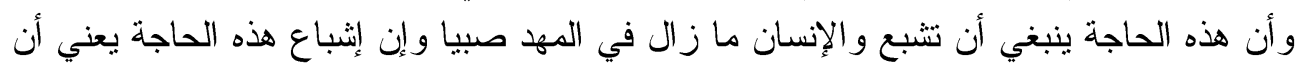




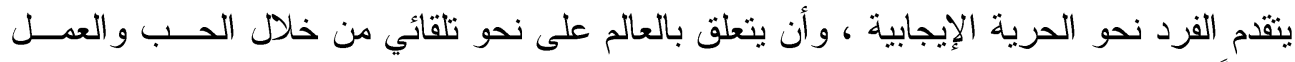

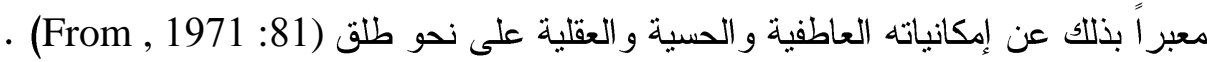

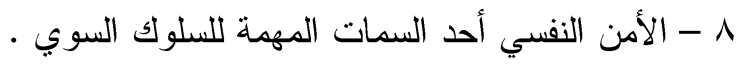

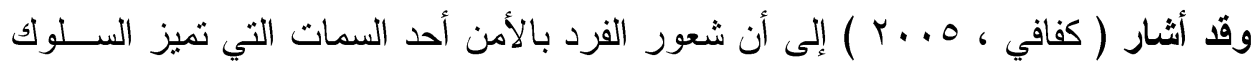

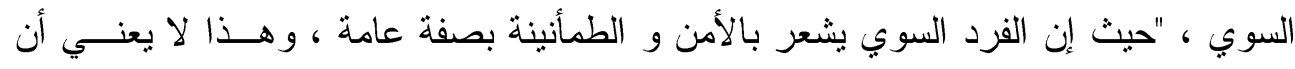

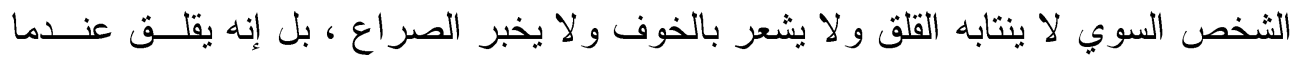

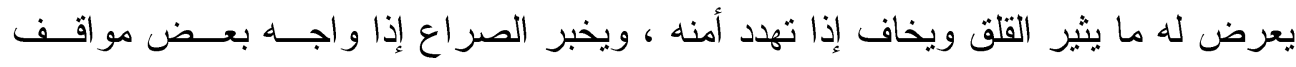

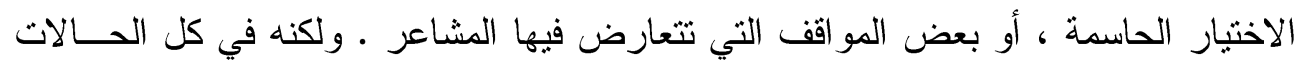

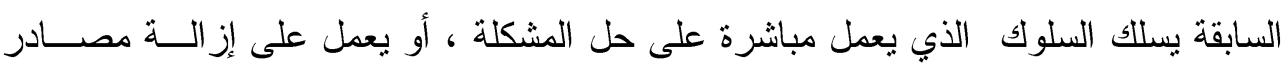

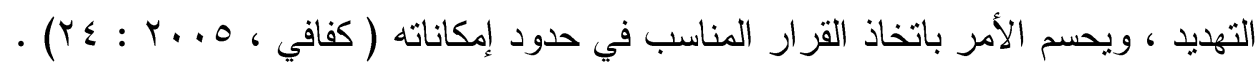

نعيش في زمن مليء بالأزمات و الاضطر ابات النفسية ، ومن هذه الاضطر ابات النفسـية إضية

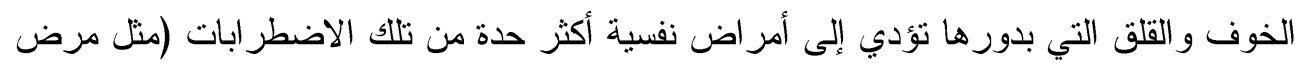

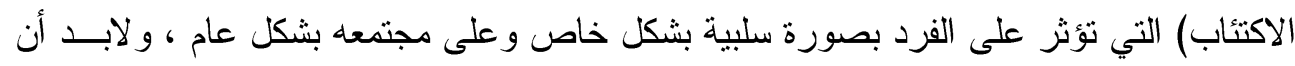

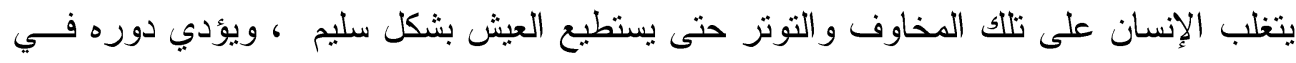

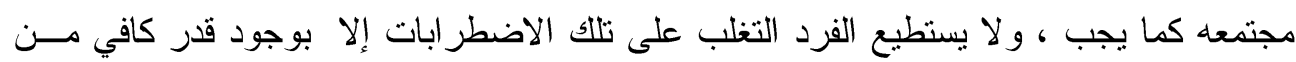

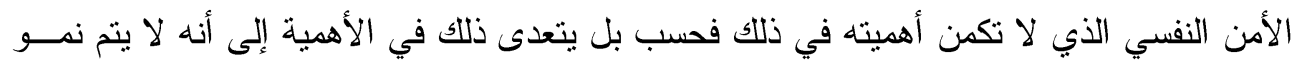

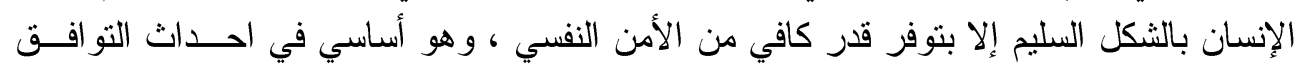

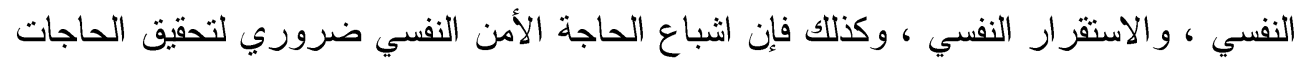

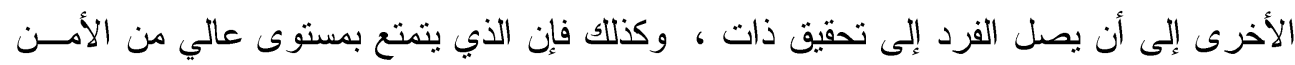

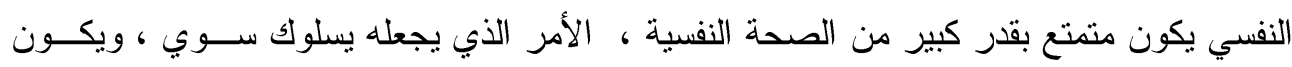
أكثر دافعية و أكثر سعادة ، ويكون أكثر نقة في الله و أكثر صبر على لفير مصائب الدنيا .

\section{ج - نثأة مفهوم الأمن النفسي - منأ}

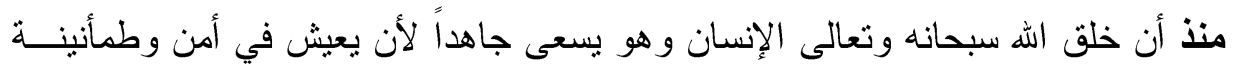

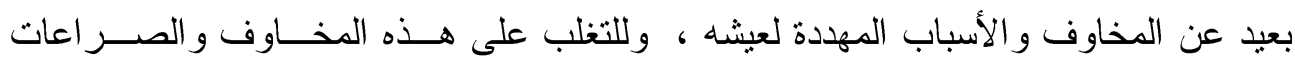

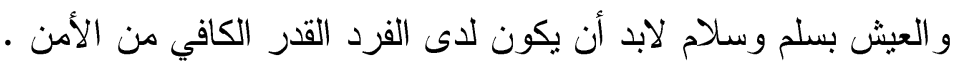

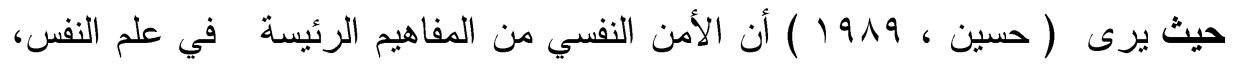

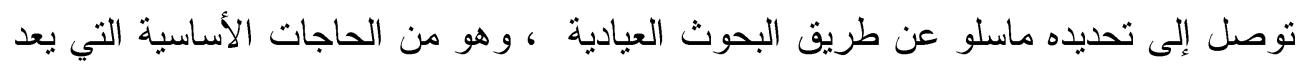


إثباعها مطلباً رئبساً لتو افق الفرد ، في حين عدم إثباعها يشكل مصدراً لقلقه وسوء نو افقــهـ

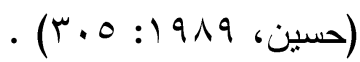

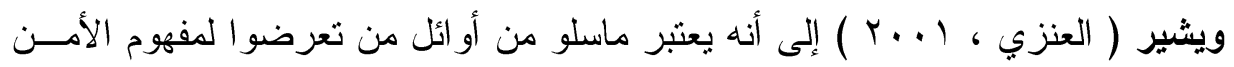

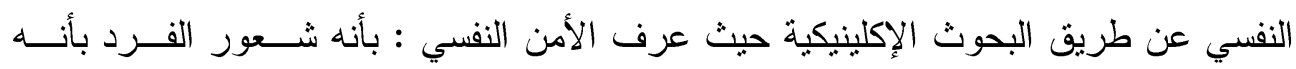

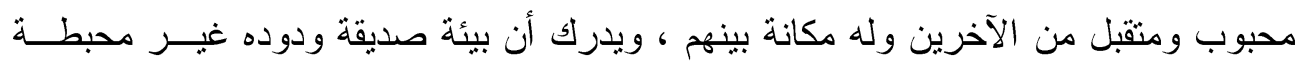

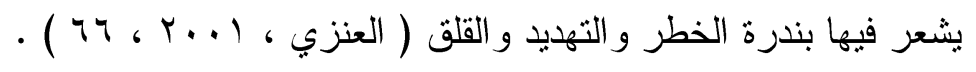

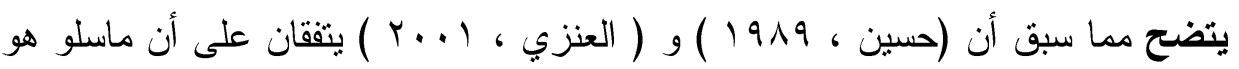

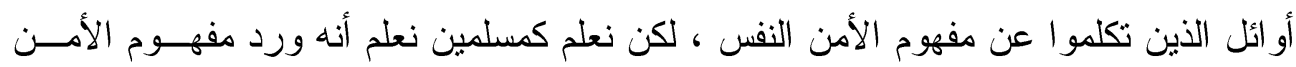

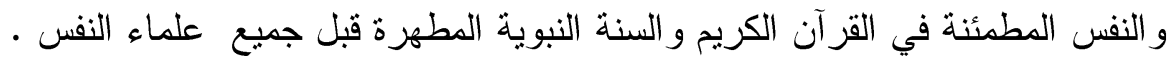

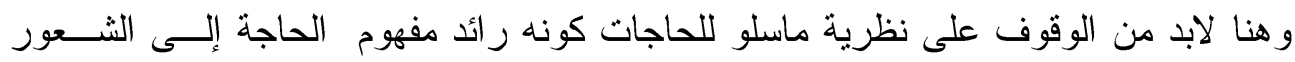

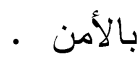

\section{د- نظرية ماسلو في الحاجات :}

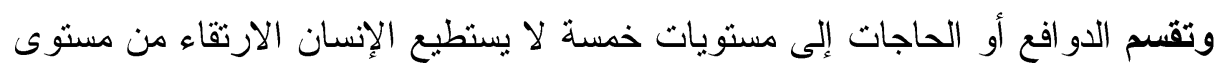

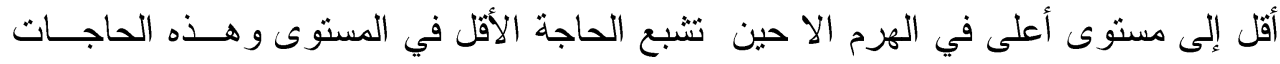

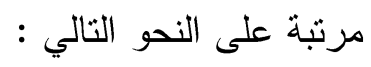

\section{1 الحاجات الفسيولوجية أو العضوية :}

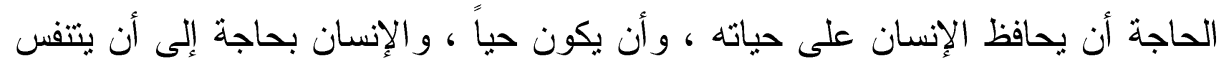

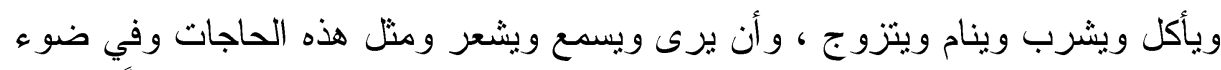

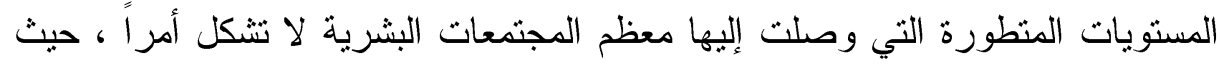

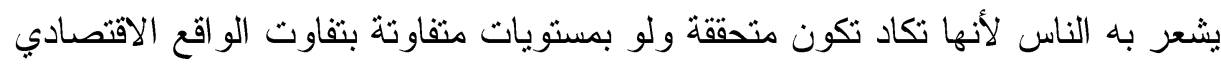

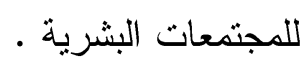

\section{r الحاجة إلى الأمن و الطمأنينة : البمرية}

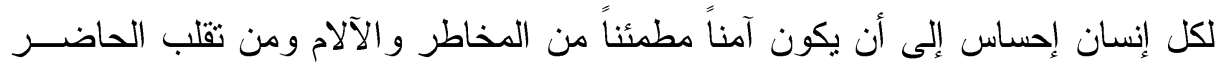

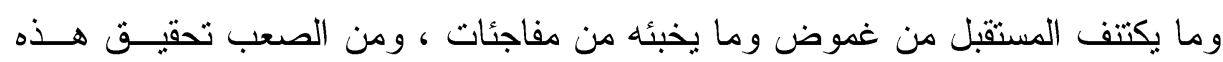

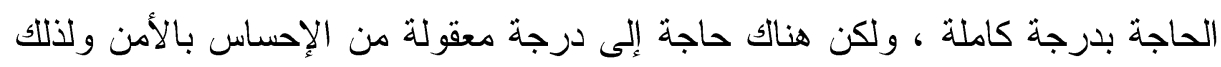

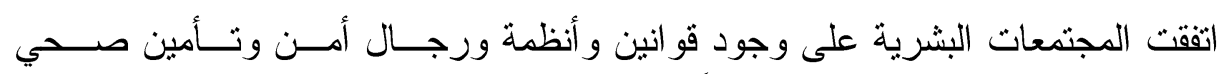

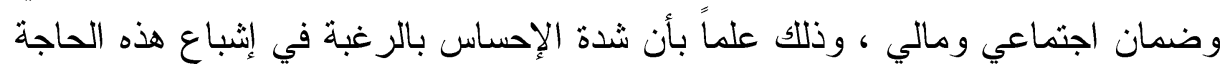

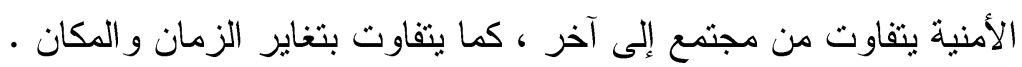


عاش الإنسان في جماعة منذ القدم وتتامت حاجته للانضمام إلى الجماعة عبر عنها في

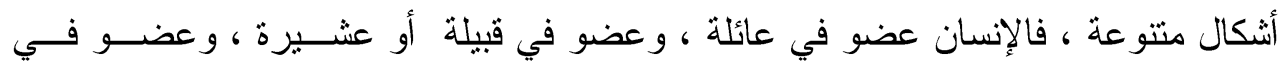

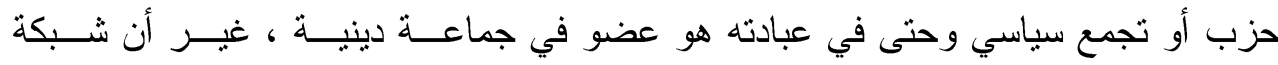

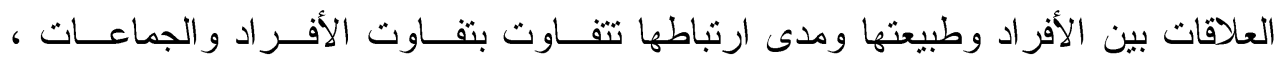

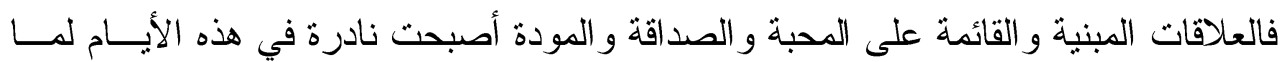

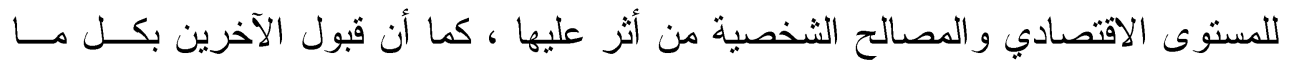

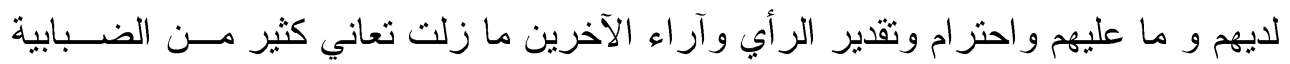

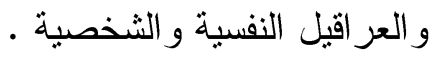

\section{ع - الحاجة إلى التقدير والاحتر ام :}

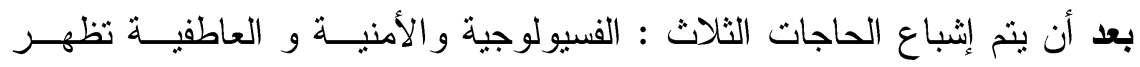

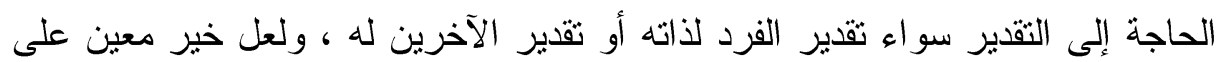

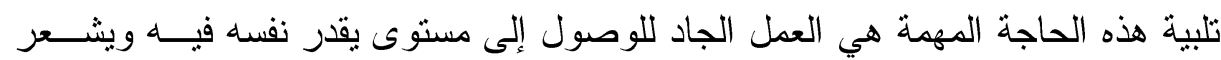

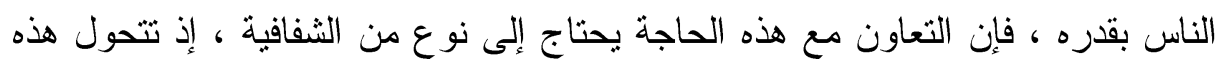

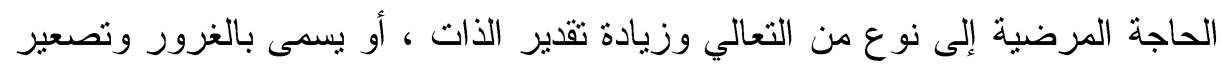

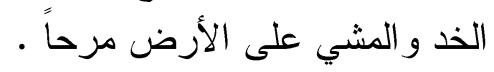

\section{ه- الحاجة إلى تحقيق الذات :}

إن الإنسان بشكل عام يميل إلى ممارسة ما يحب و إلى حب ماتى ما يمارس مع أن القليلين

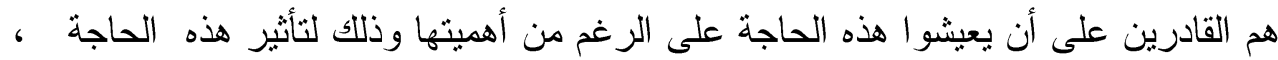

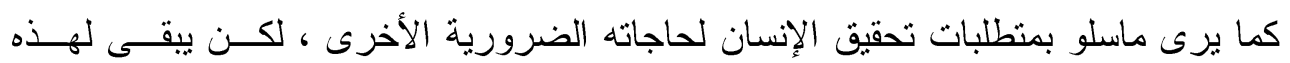

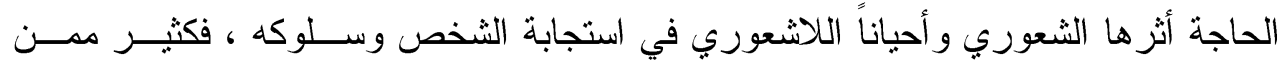

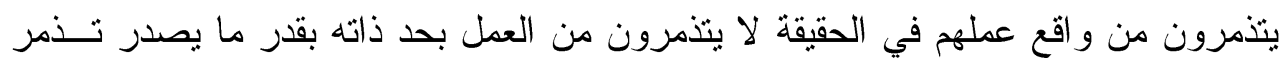

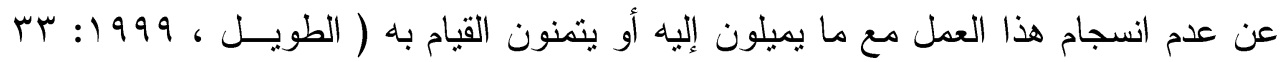

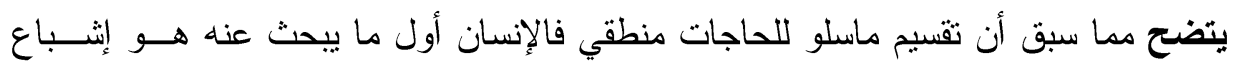

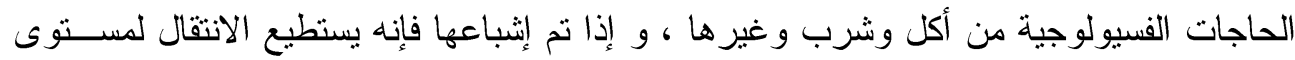

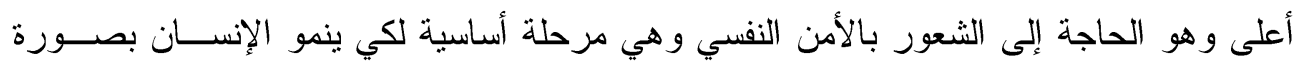




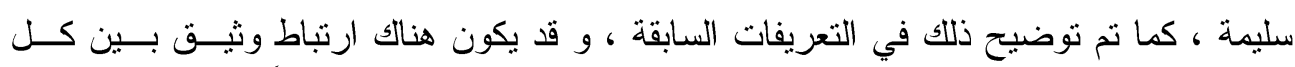

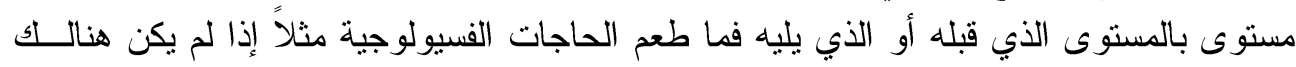

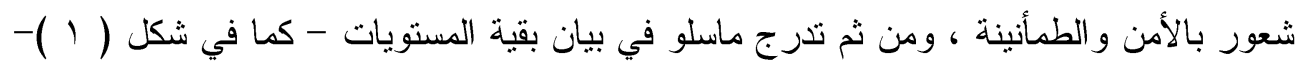

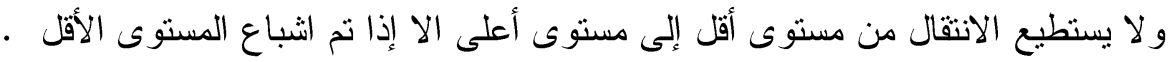

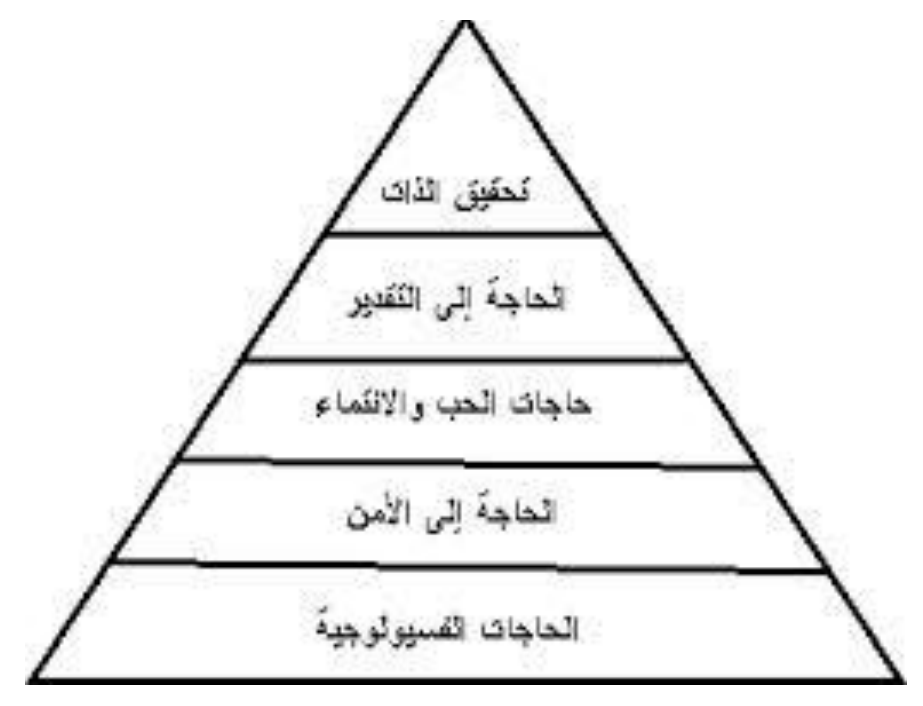

هرم ماسلو للاحتياجات الإسانية

شكل (1) ماسكو للاجئات

هـ - أبعاد الأمن النفسي :

كلأمن النفسي ثلاثة أبعاد ، تتمثل في شعور الأفي : الفرد:

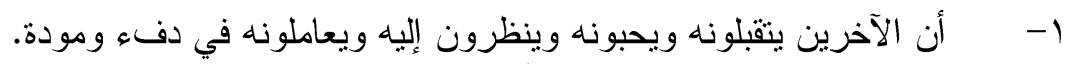
r ب بالانتماء و الإحساس بأن له مكاناً في الجماعة.

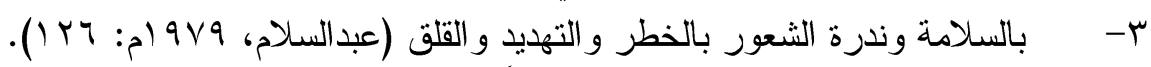

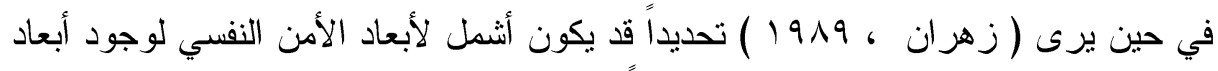

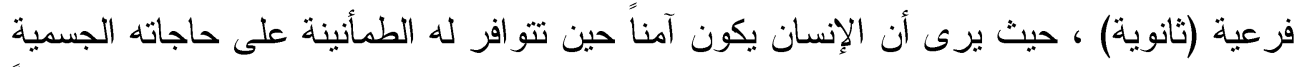

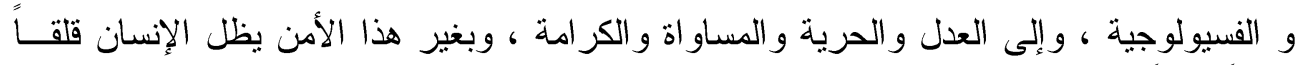

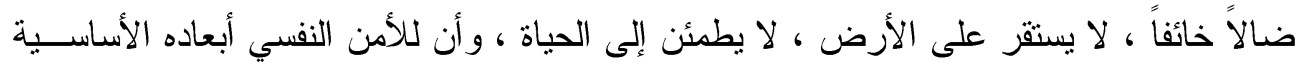

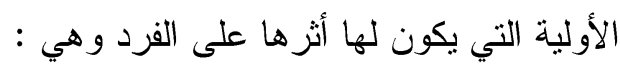

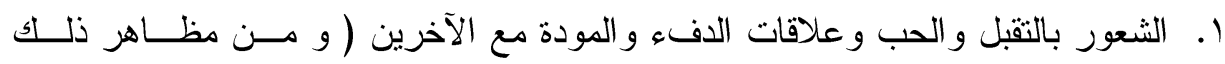

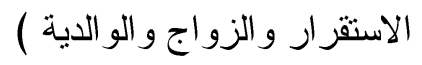


r. الثعور بالانتماء إلى الجماعة و المكانة فيها ، وتحقيق العمل الذي يكفل له حياة كريمة .

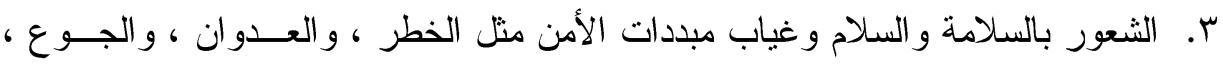

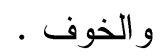

كما يشير إلى وجود أبعاد فرعية ثانوية للأمن النفسي لها أثرها على الفرد تتمثل في التالي : 1. إدر الك العالم و الحياة كبيئة سارة دافئة ، يشعر من خلالها بالكر امسـة ، و العــدل و الارتياح.

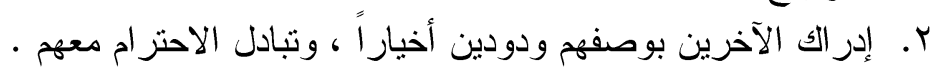

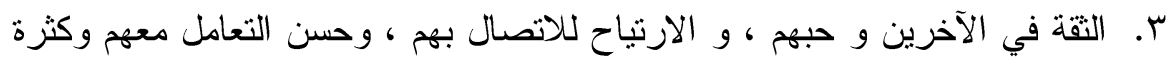

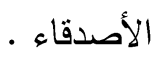

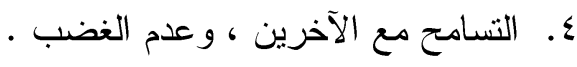

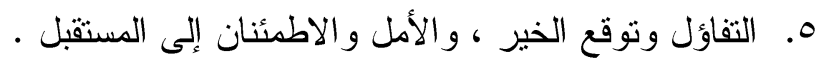

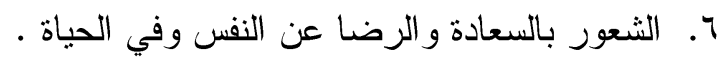

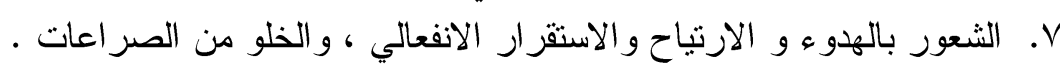

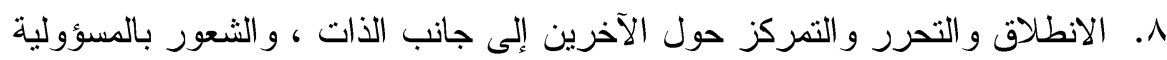

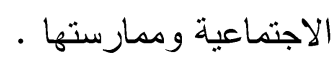

9. تقبل الذات و التسامح معها و الثقة في النفس ، و الثعور بالنفع و الفائدة في الحيــاة .

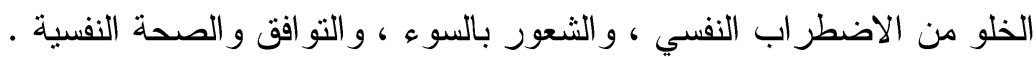

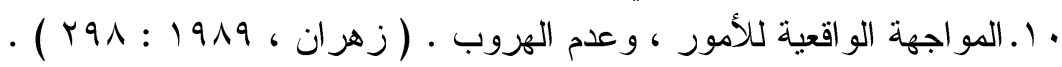

\section{تعقيب}

يتضـح أن أبعاد الأمن تركز على انتماء الفرد لجماعة من الناس يشعر من خلالهـــا

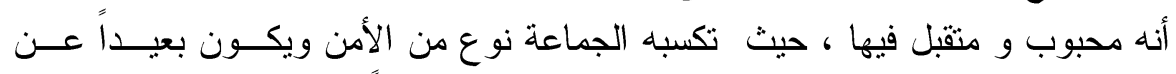

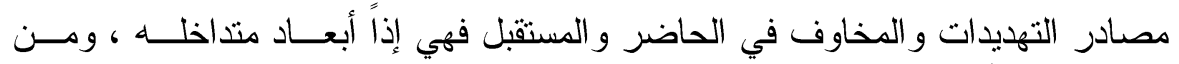

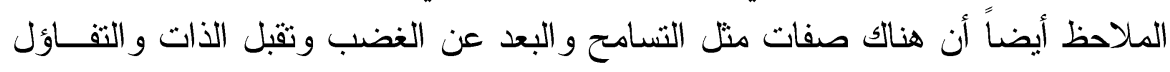

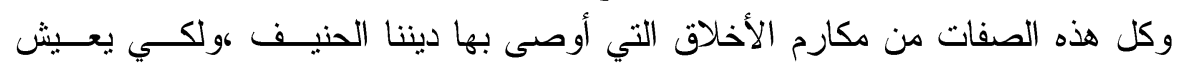

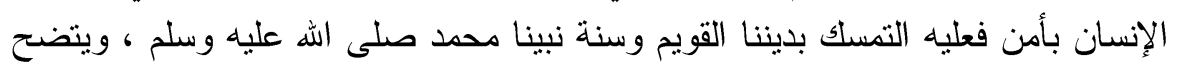

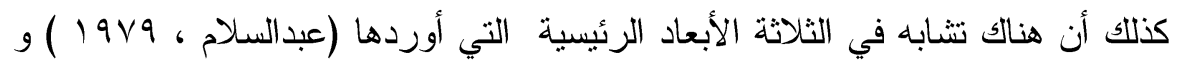

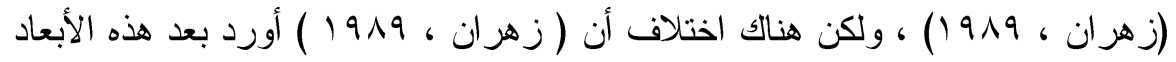

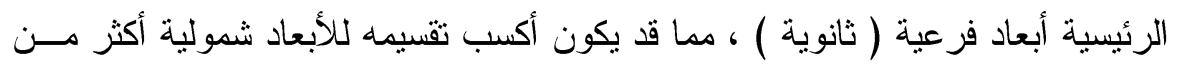

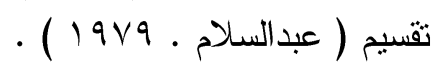




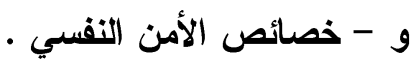

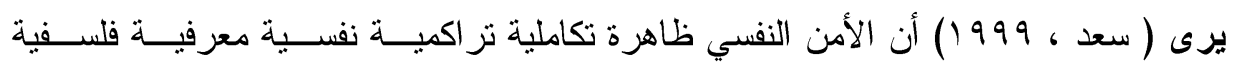

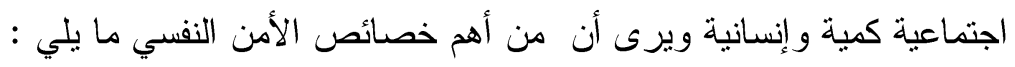

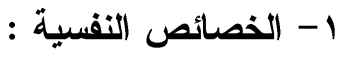

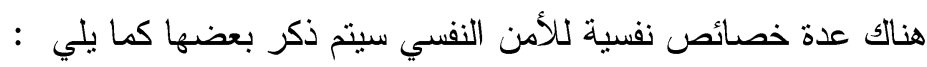

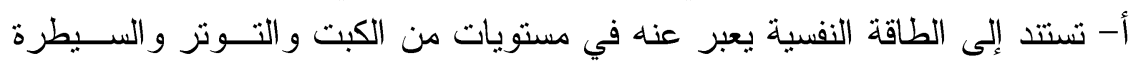

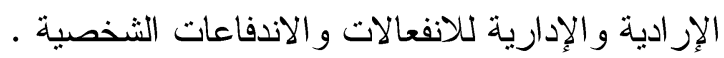

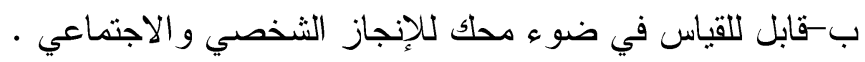

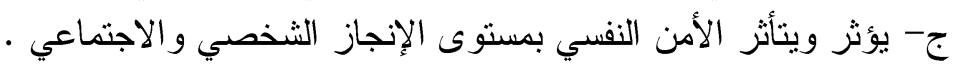

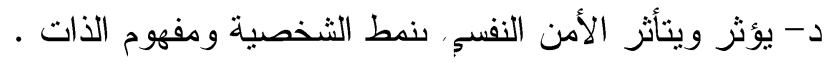

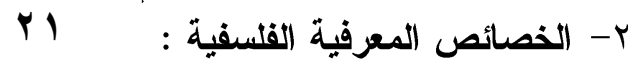

هناك عدة خصائص معرفية فلسفية للأمن النفسي سيتم ذكر بعضها كما يلي :

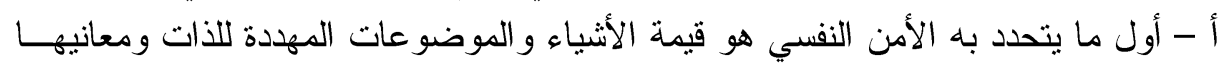
المعرفية.

ب - أن التكوين المعرفي الفلسفي يلعب دوراً مهماً في تكوين صورة ذهنية عن مهـددات

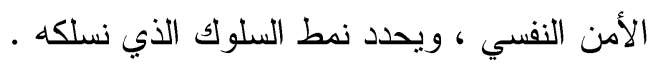

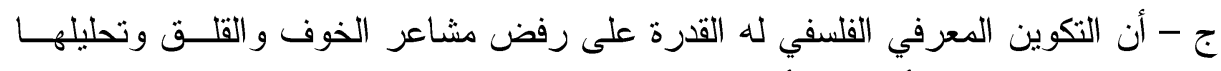

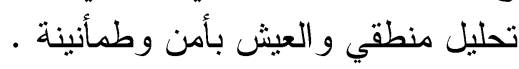

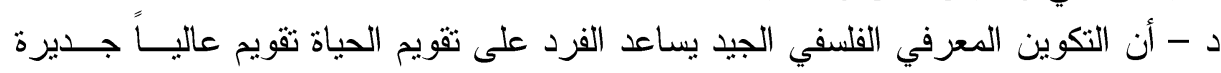

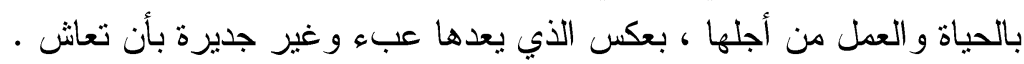

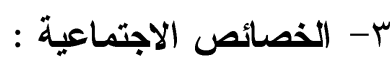

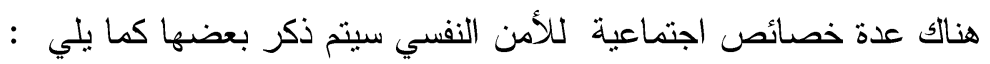

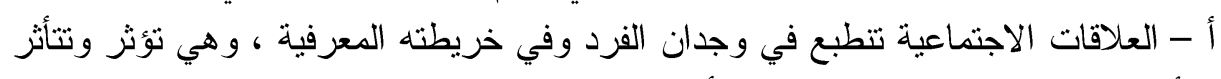

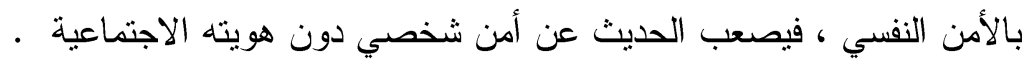

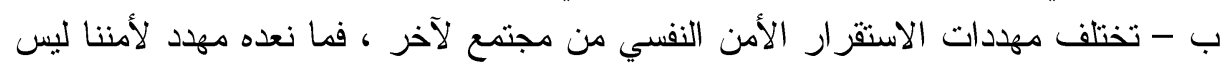
بشرط أن يكون مهدد للأمن النفسي في مجتمع آخر الأن الأن

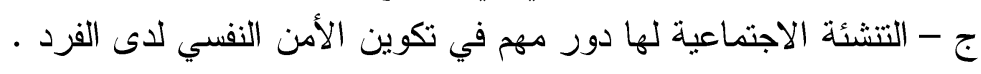

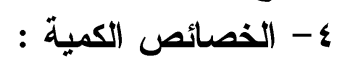

أ - الأمن النفسي مفهوم كمي يمكن قياسه ، حيث يظهر في شكل سلوك أو طاقة .

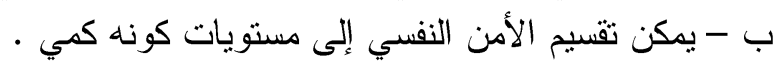


ج - الفهم الكمي للأمن النفسي يوفر إمكانية التــدخل العلمــي علــى مســتويات القيــاس

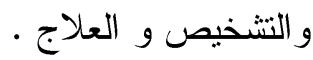

\section{ه- الخصائص الإنسان :}

أ - الأمن النفسي سمة يشترك فيها أبناء البشر مهما كانت مراحلهم العمرية أو مســتوياتهم

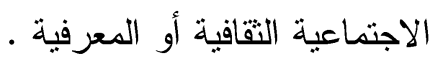
ب - يعتبر الأمن النفسي سمة إنساني وتحصين العيعة هذه السمه مهمة إنسانية .

يتضح مما سبق أن الخصائص المكونة للأمن النفسي متر ابطة وتر اكمية تتكون خلال

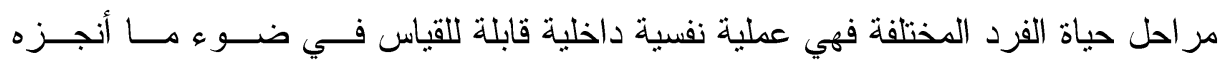

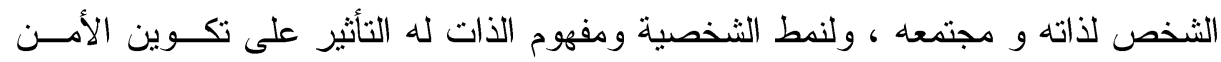
و هذا كلام منطقي لأن شخصية الفرد الحساسة كمثال قد يكون لايها الأمن النفسي أقل من

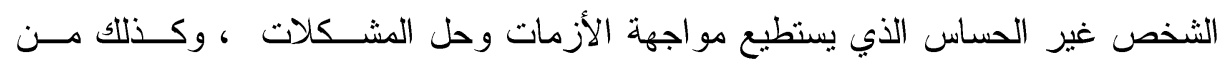

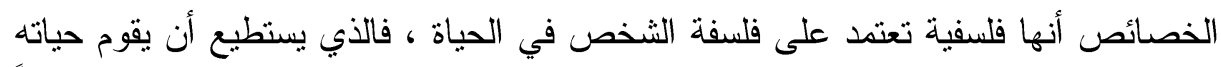

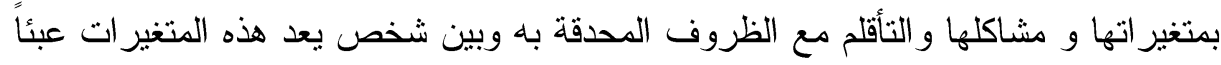

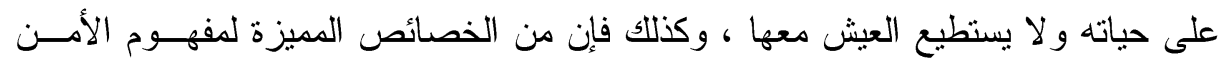

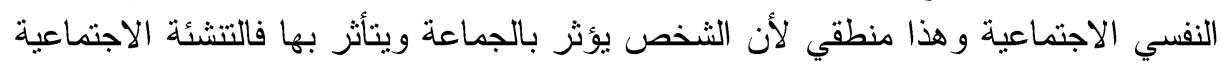

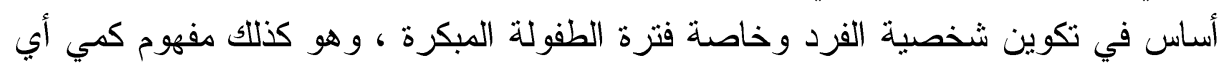

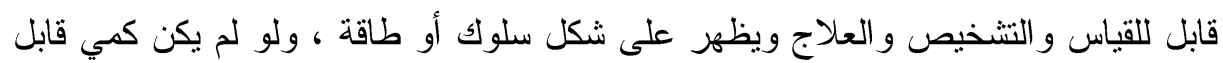

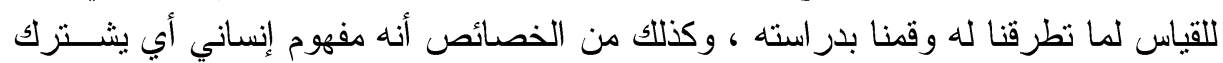

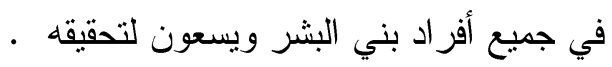

\section{ز - الآثار المترتبة على فقدان الأمن النفسي :}

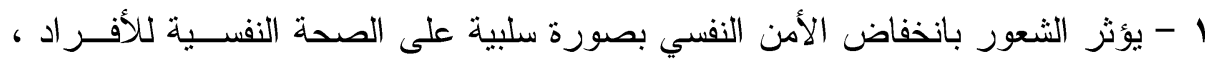

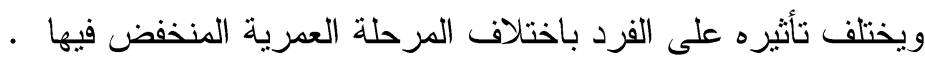

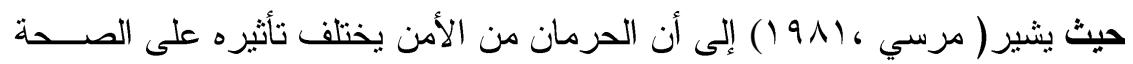

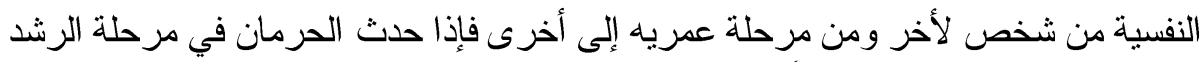

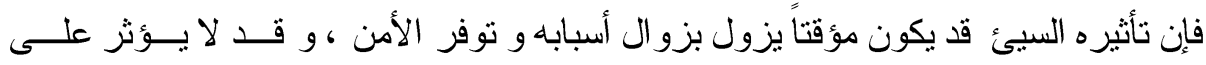

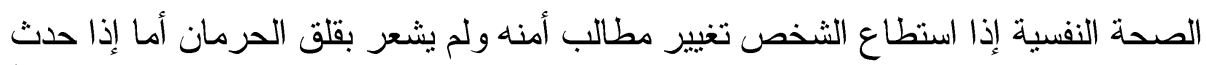

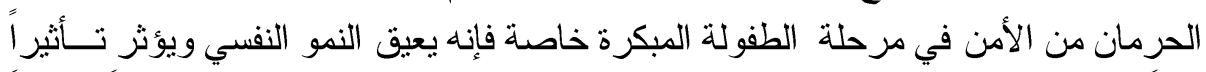

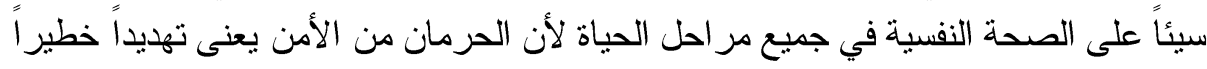




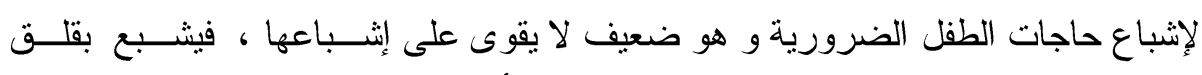

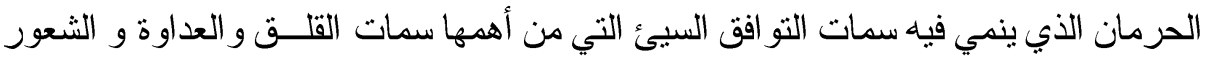

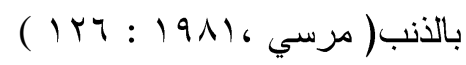

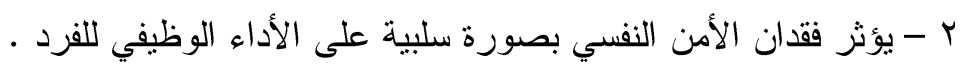

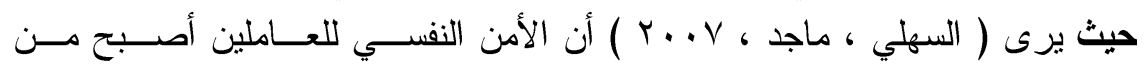

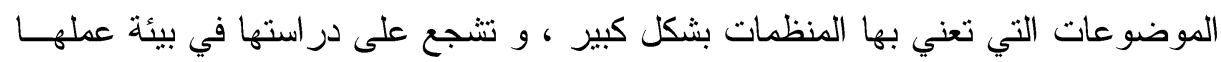

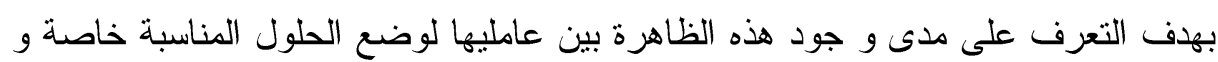

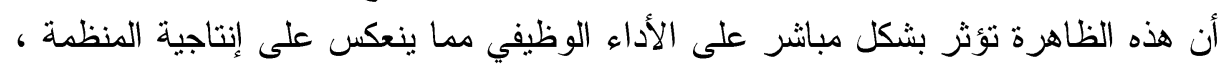

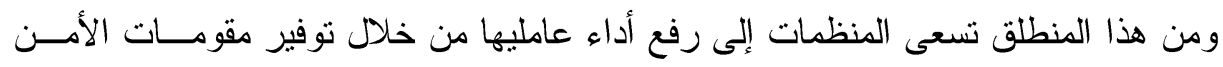

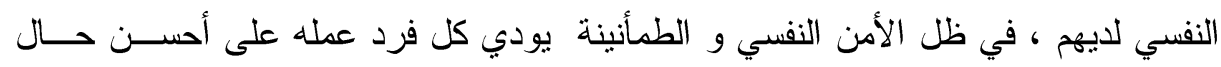

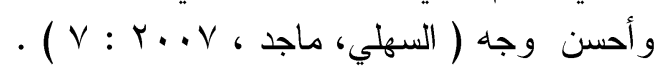

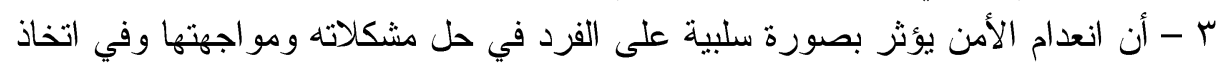

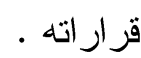

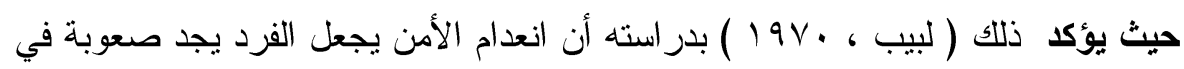

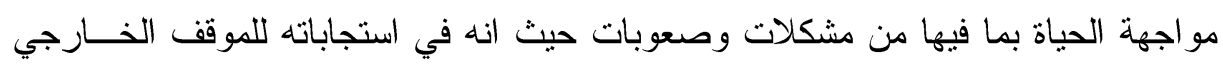

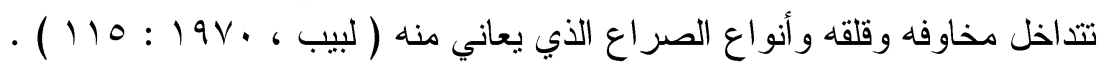

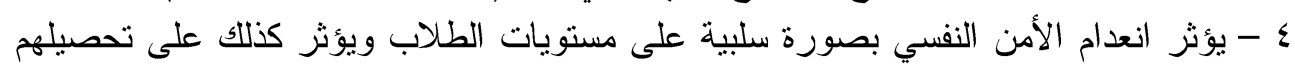
الدر اسي.

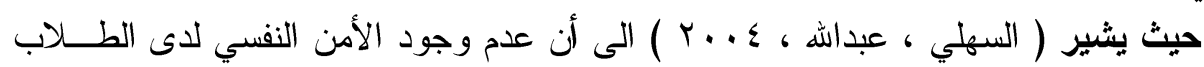

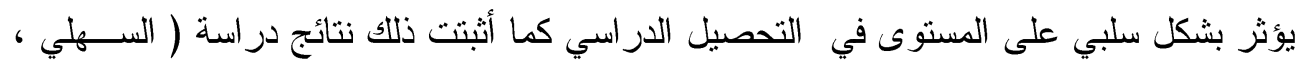
. ( $\wedge 7:$ : r..

ه - أن عدم الشعور بالأمن يؤثر بصورة سلبية على نمو الفرد بكافة اشكاله المختلفة

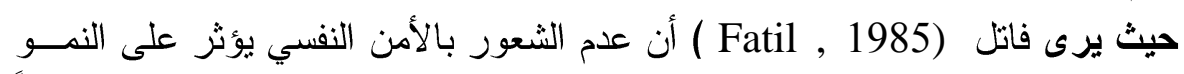

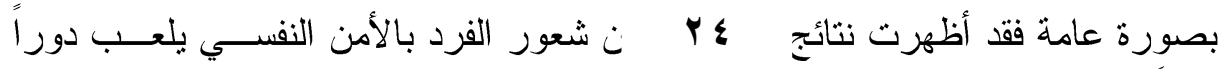

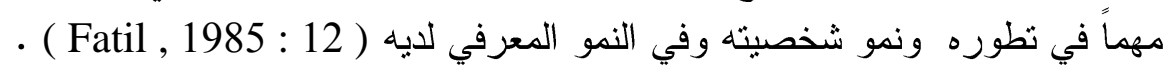

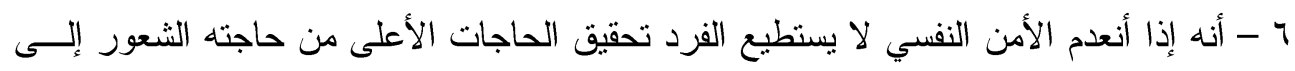

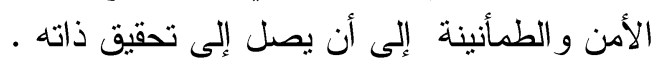

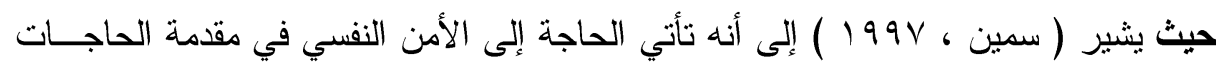

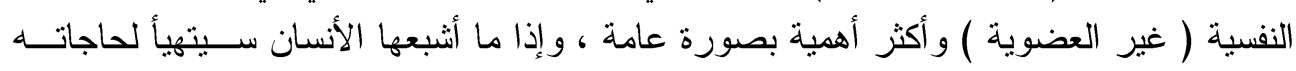




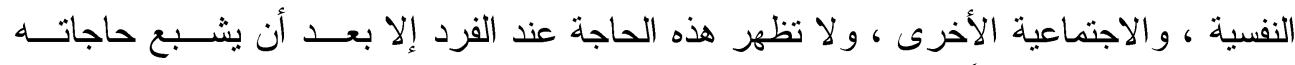

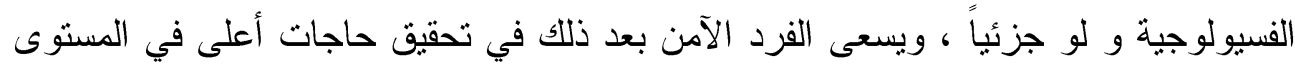

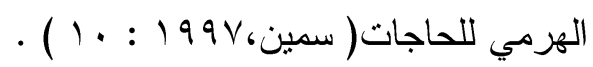

تعقيب

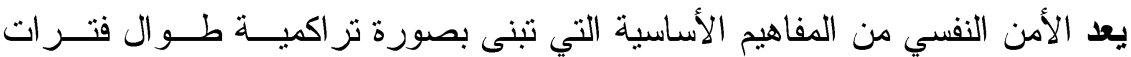

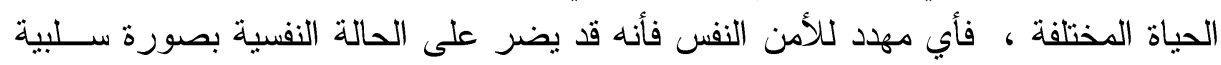

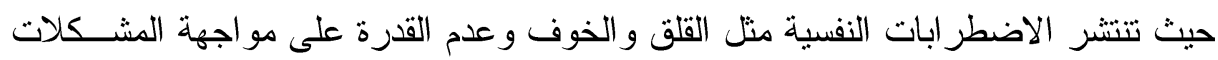

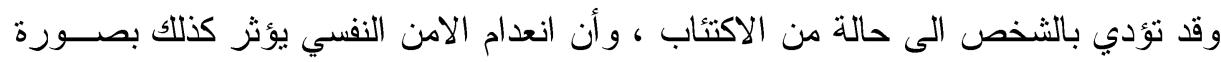

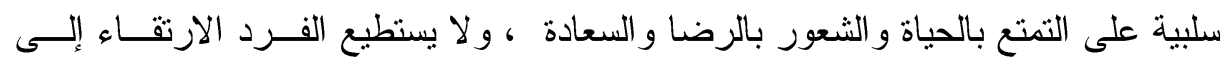

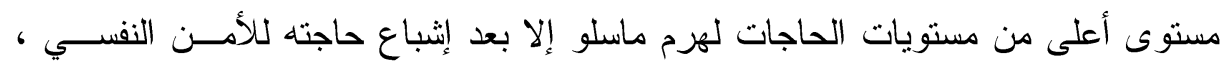

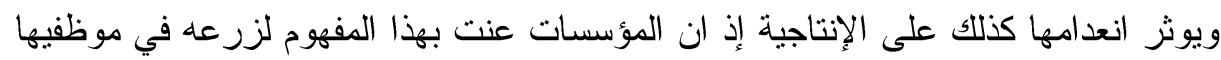

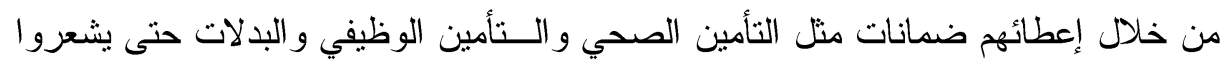

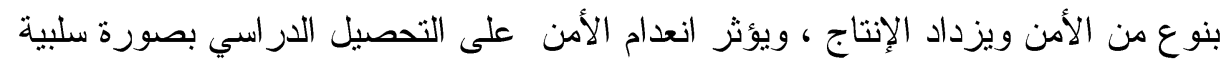

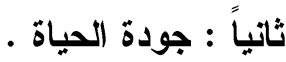

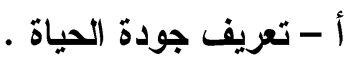

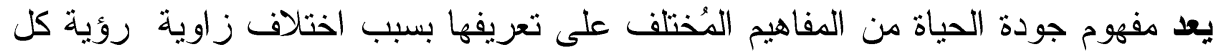

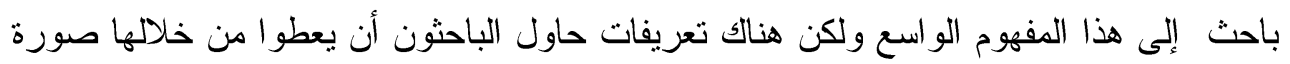

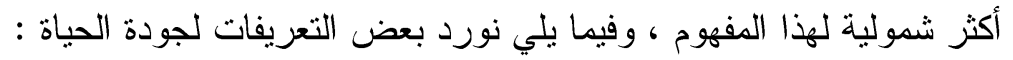

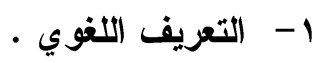

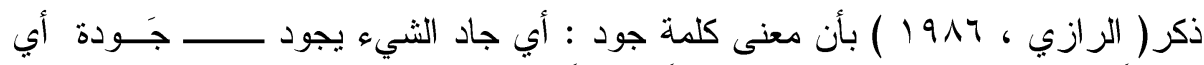

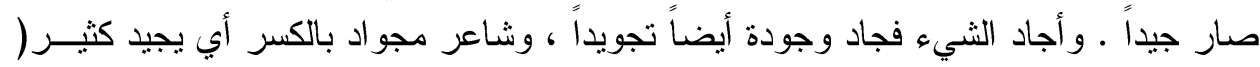

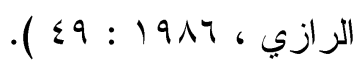

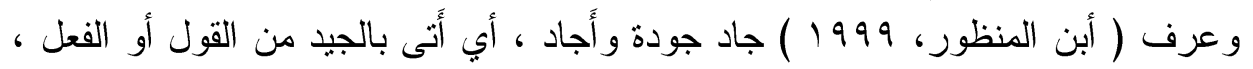

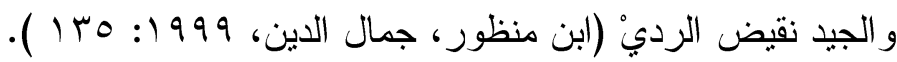

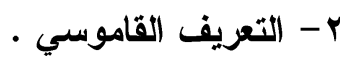

عرفها ( الثربيني ، r . . r ) على أنها هي التعبير عن الحالة الإيجابية من الصحة البدنية

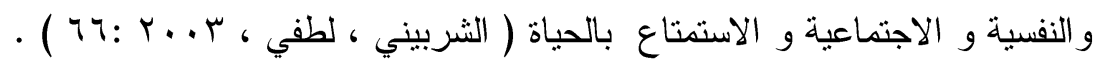

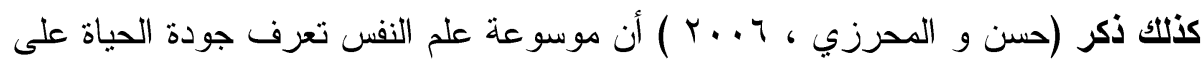

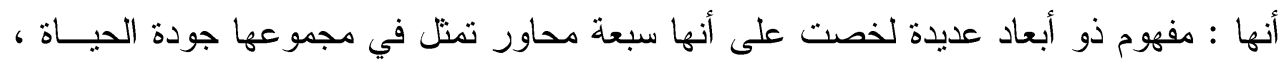

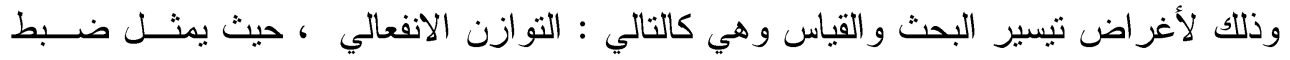


الانفعالات الإيجابية و الانفعالات السلبية ، كالحزن و الكآبة و القلق و الضغوط النفسية ، و الحالـــة

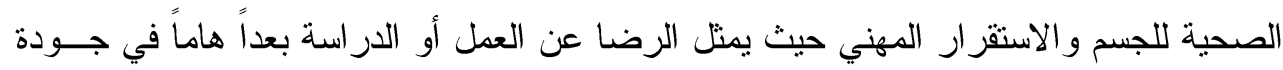

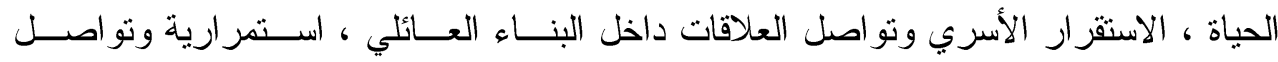

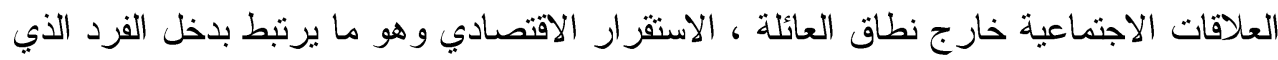

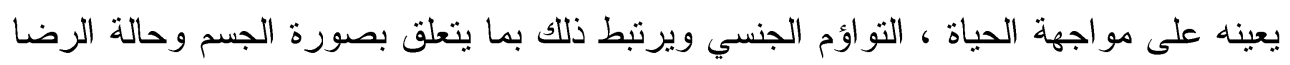

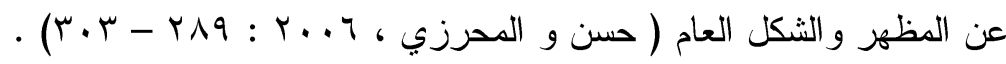

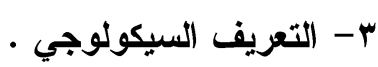
عرف بعض الباحثين جودة الحياة بناء على تقييمه للأوضاع السائدة في البلدان و أغفلوا

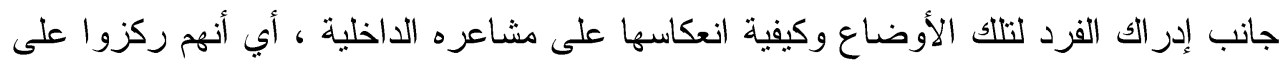

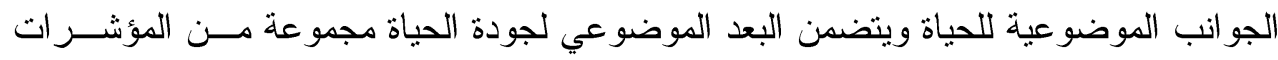

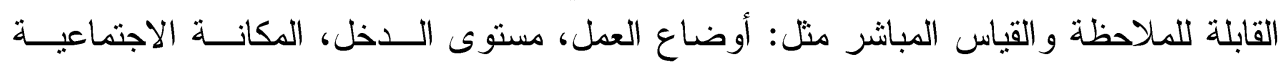
الاقتصادية، وحجم المساندة المتاح من شبكة العلاقات الاجتماعية ، وسلك الباحثون في تعريفاتهم

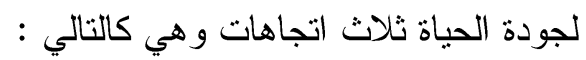

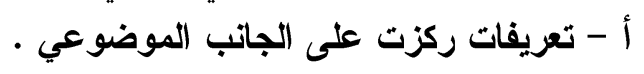

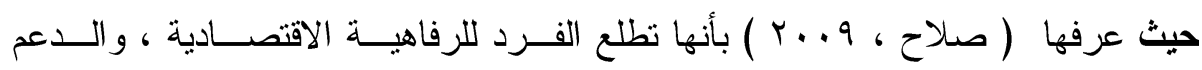

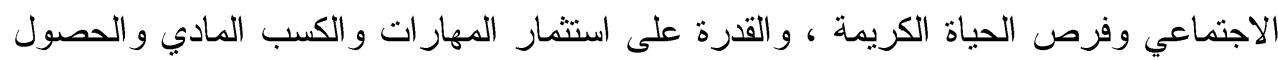

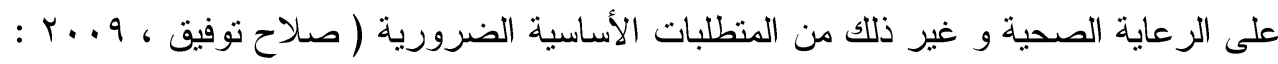
. ( 1 ro

ب - تعريفات اعتمدت على بعد واحد من أبعاد جودة الحياة .

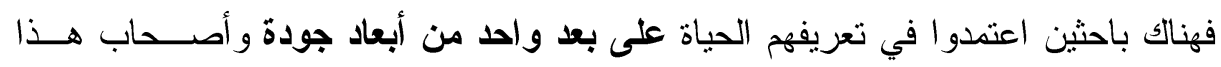

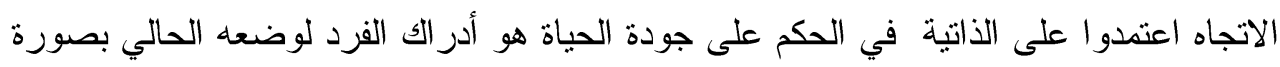

ذاتية

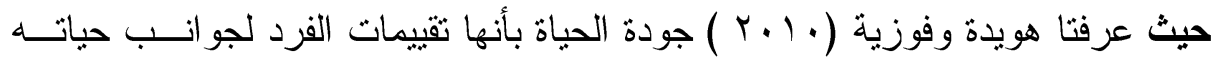

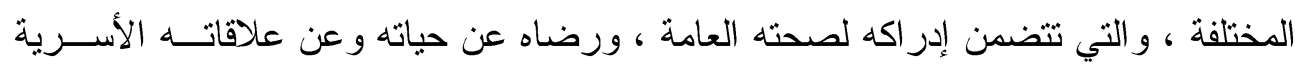

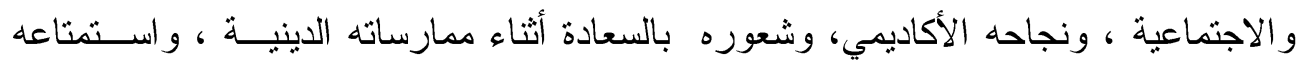

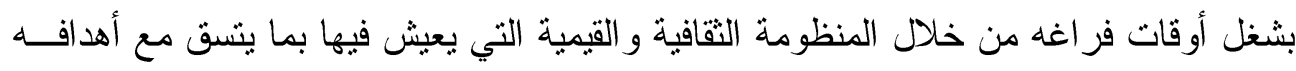

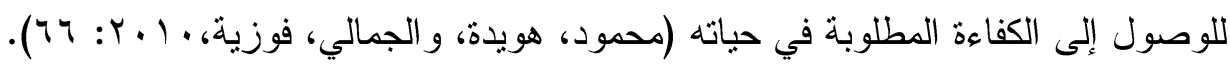

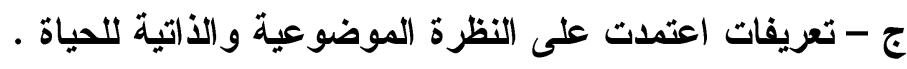
وهو اتجاه أكثر شمولية في النظر إلى مفهوم جودة النمرة الحياة . 


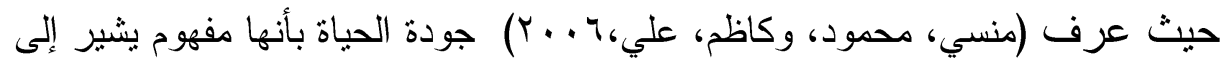

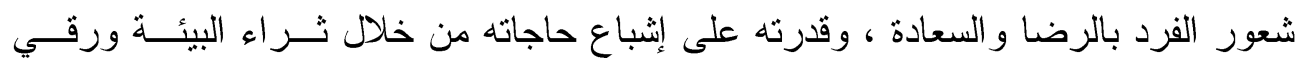

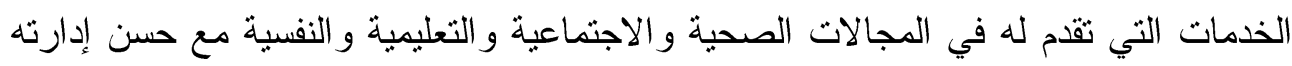

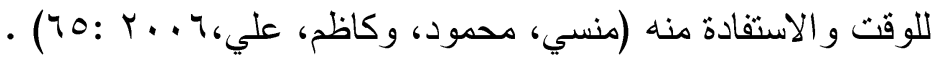

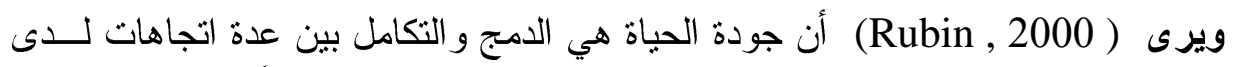

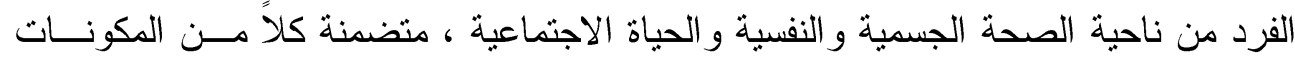

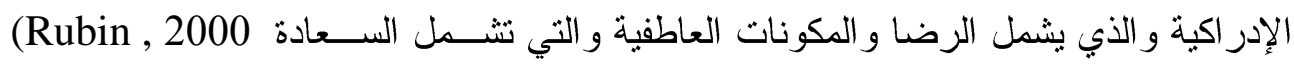

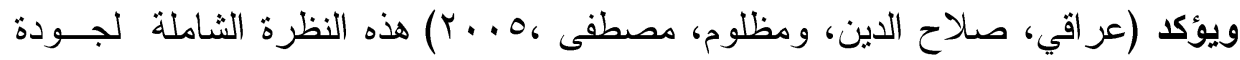

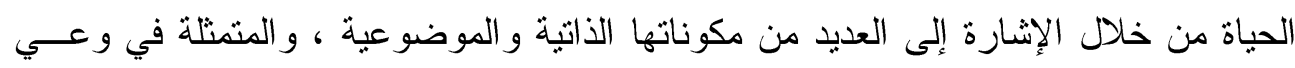

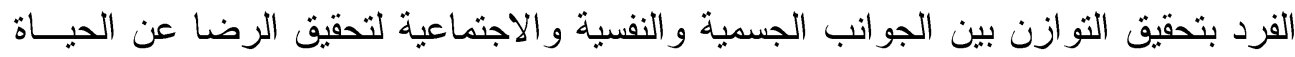

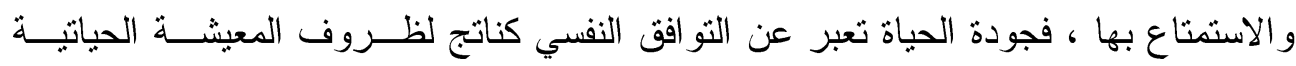

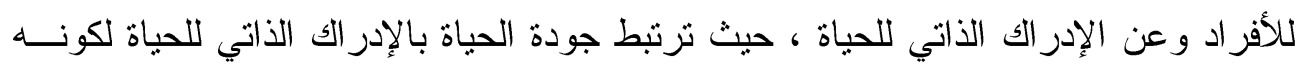

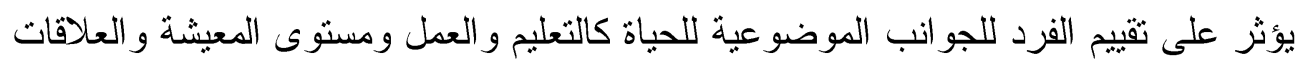

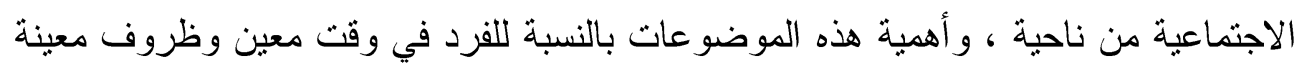

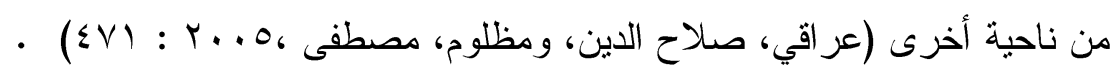

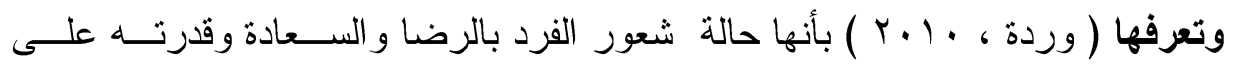

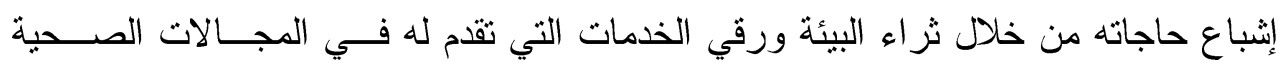

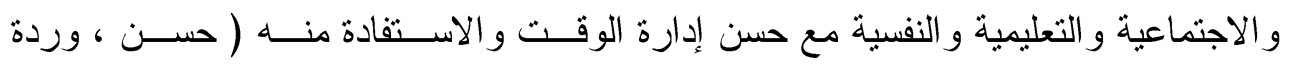

$$
\text { (1.: (1.). }
$$

تعقيب

نلاحظ أن هناك ثلاث اتجاهات في التعاريف السابقة حيث أن جزء من الباحثين ركزوا فــي

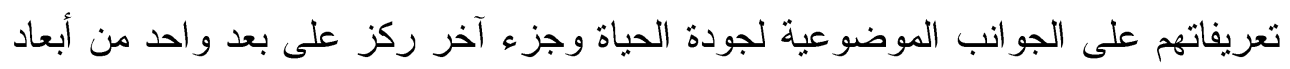

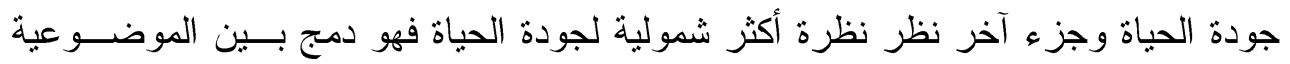

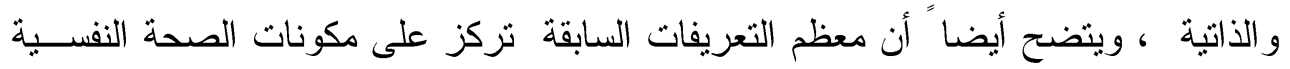

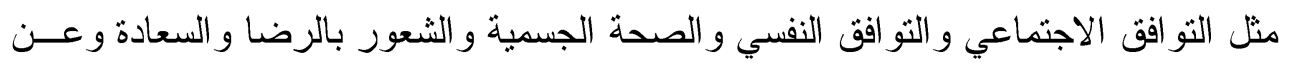

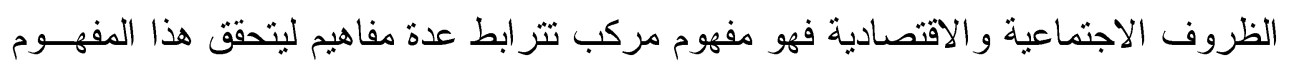
الشامل . 


\section{ب - أبعاد مفهوم جودة الحياة .}

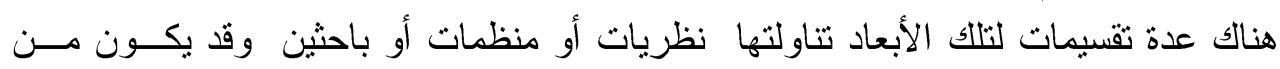

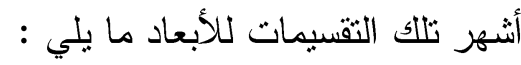
1- تقسيم نظرية ( Ryff , 1989 ) التي تدور حول مفهوم السعادة النفســية إذ أن شــعور

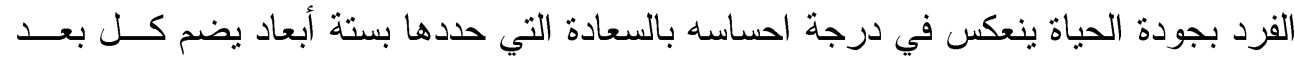

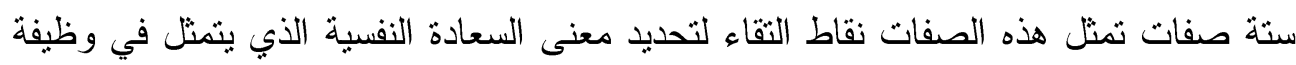

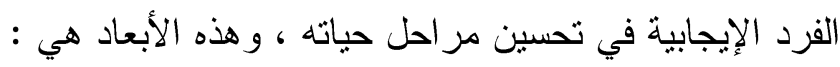

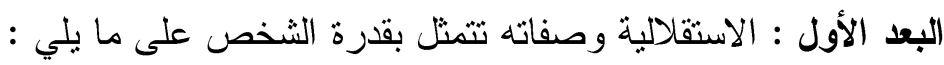

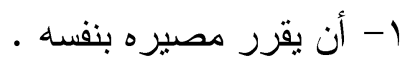

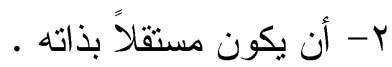

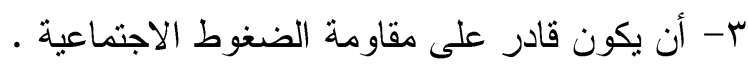

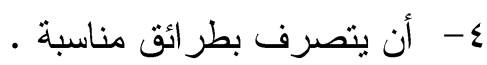

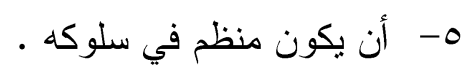

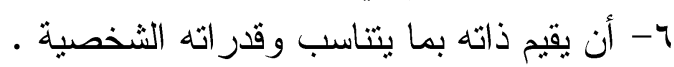

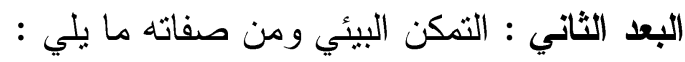

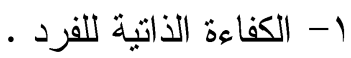

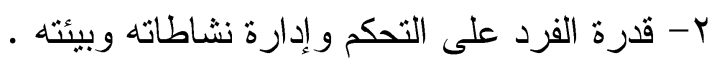

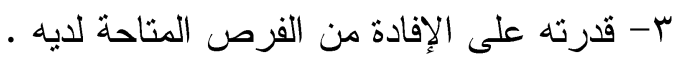

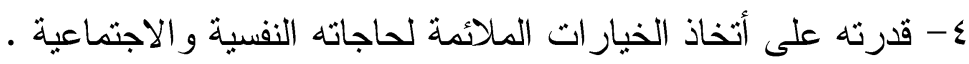
0- قدرثه على اختبار قيمته الثخصية . צ- قدرته على التصرف بما يتناسب ومعايير مجتمعه .

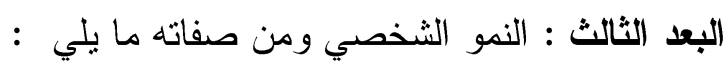

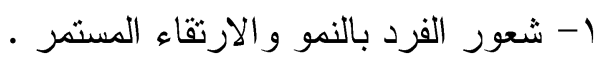

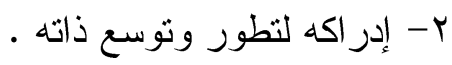

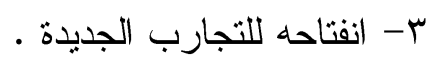

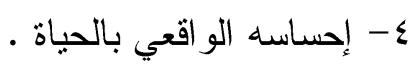

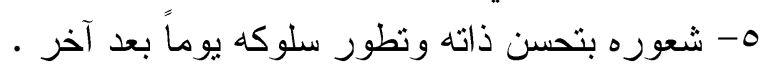

4- سلوكه يتغير بطر ائق تزيد من معرفته وفاعليته الذاتية .

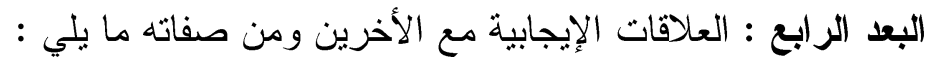

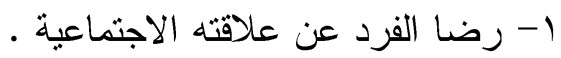




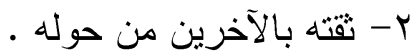

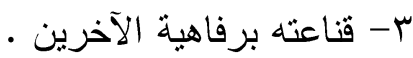

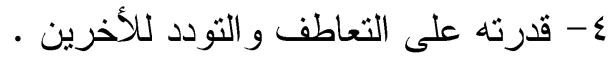

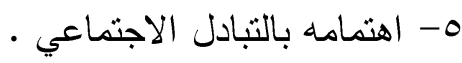

צ- اظهاره للسلوك النو اصلي مع الأخرين •

البعد الخامس : تقبل الذات ومن صفاته ما يلي :

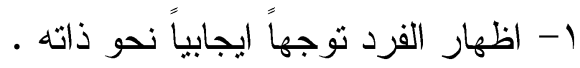

r- قبوله بالسمات أو الخصائص المكونة لذاته ( السلبية و الايجابية ) .

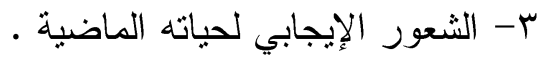

ع - تفكيره الإيجابي لذاته المستقبلية .

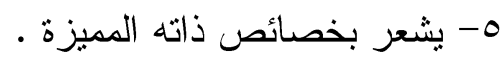

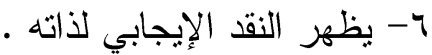

البعد السادس : الهدف من الحياة ومن صفاته ما يلي :

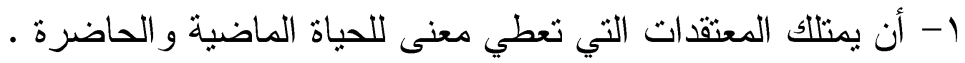

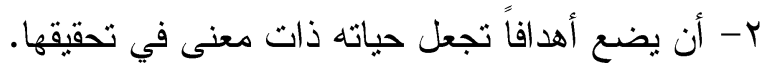

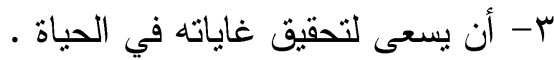

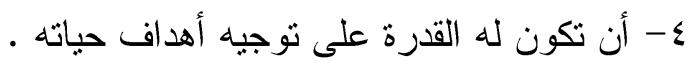

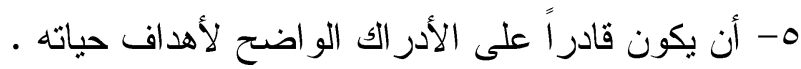

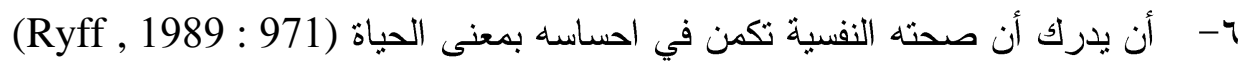

لقد بين رايف ( Ryff , 1989 ) أن جودة حياة الفرد تكمن في قدرته على مو اجهــة

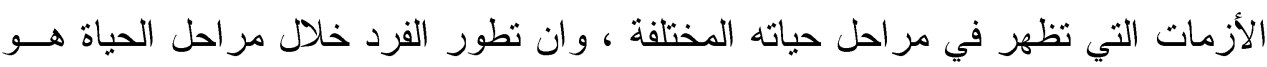

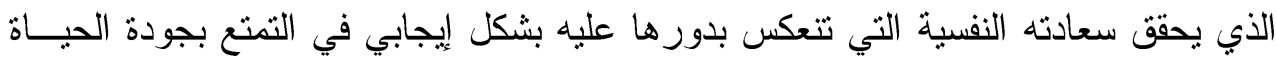
ومن الملاحظ ايضاً ان الأبعاد التي حددها رايف قد نكون شاملة لجميع أبعاد جودة الحياة .

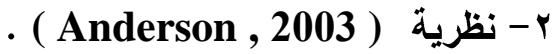

ذكر (Ventegodt 2003) أن اندرسون طرح شرحاً تكاملياً لمفهوم جودة الحياة متخــذاً

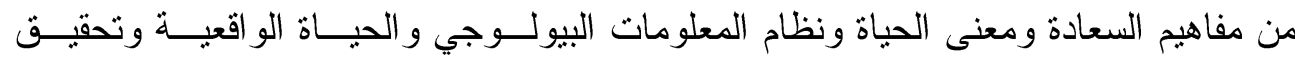


الحاجات النفسية فضلاً عن العو امل الموضوعية الأخرى اطارًا نظرياً تكاملياً لتفسير جـودة الحياة ( 141:

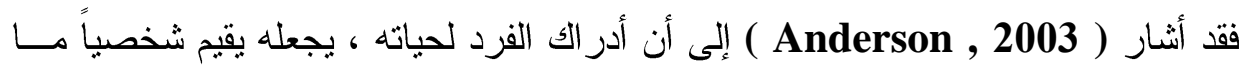

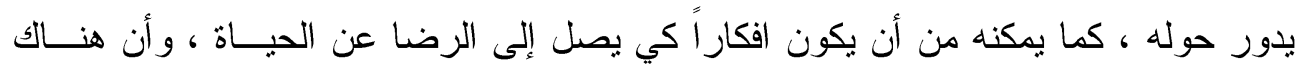

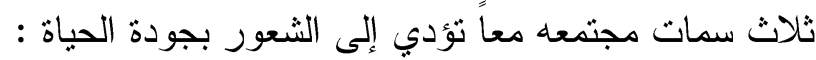

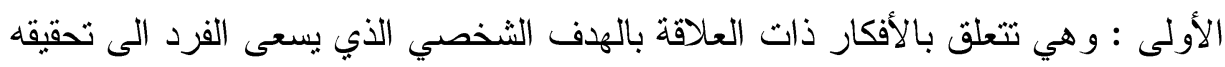

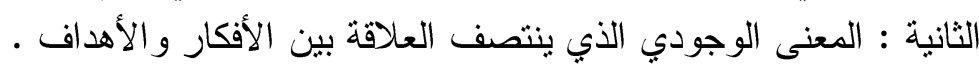

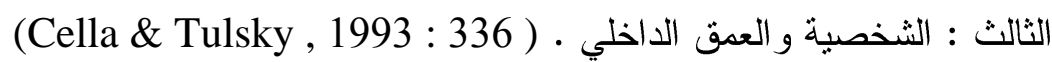
وفي ضوء هذه السمات فان النظرية التكاملية تضع المؤشرات الآتبة الدالة على جودة الحئ الحياة:

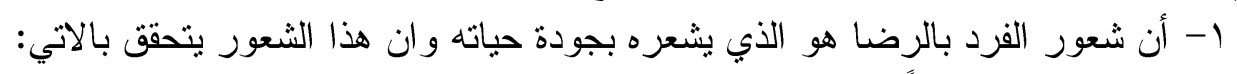

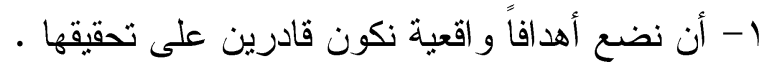
r- أن نسعى إلى تغيير ما حولنا لكي يتلاعم مع أهدافنا..

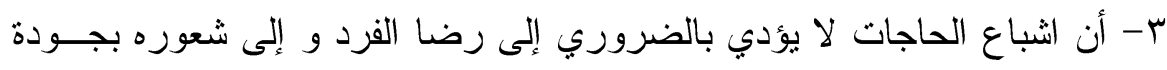

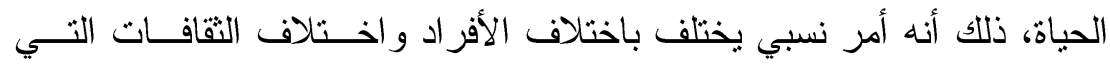

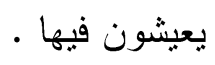

ع- أن استغلال الفرد لإمكاناته في نشاطات إبداعية ، و علاقات اجتماعية جيــدة ،

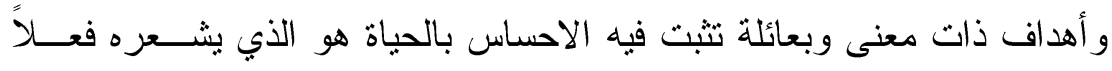

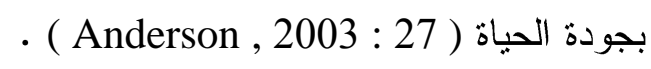

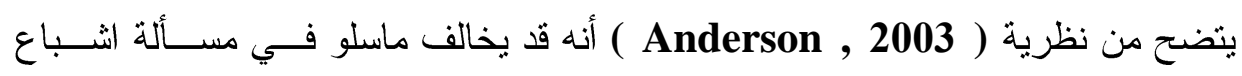

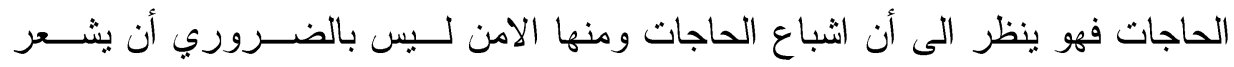

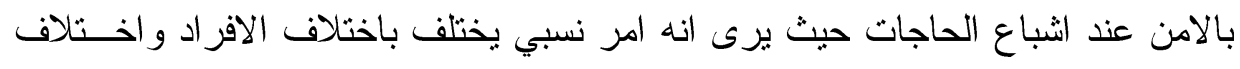

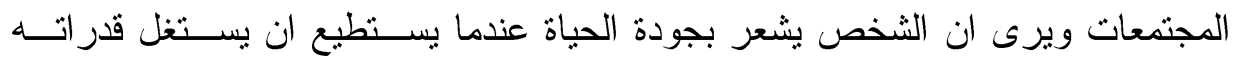

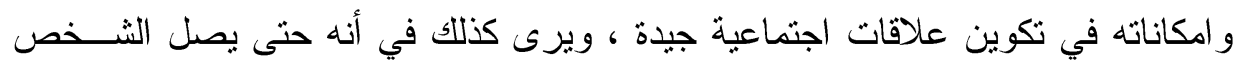

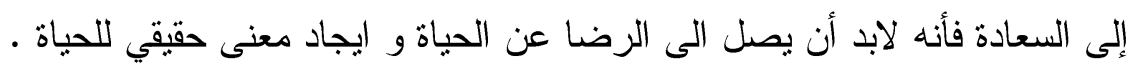

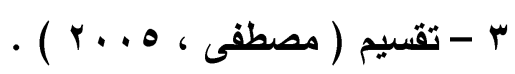

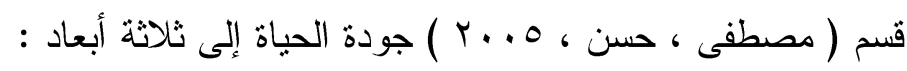

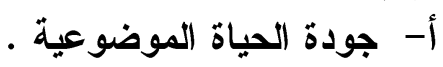

تعني ما يوفره المجتمع لأفر اده من إمكانات مادية ، إلى جانب الحياة الاجتماعيــة الثخصية للفرد . 
ب- جودة الحياة الأتية .

تعني كيف يشعر كل فرد بالحياة الجيدة التي يعيشها ، أو مدى الرضـا و القناعــة

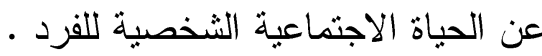

ج- جودة الحياة الوجودية .

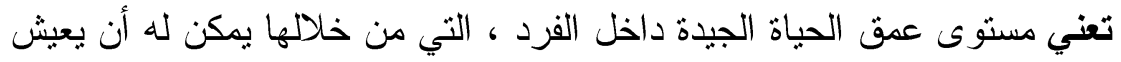

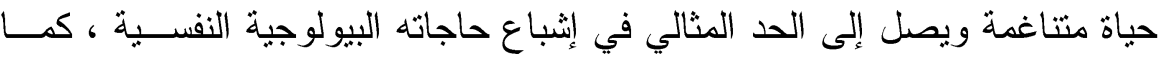

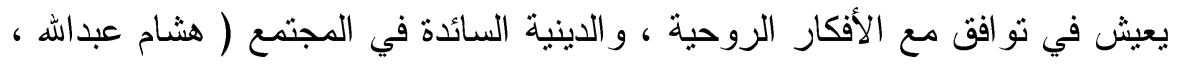

$$
\text { ( } 1 \leqslant \Lambda: \text { : r.. }
$$

تعقيب .

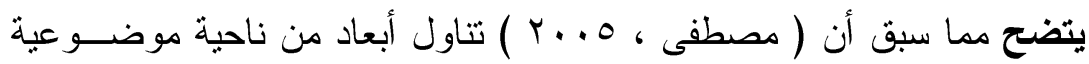

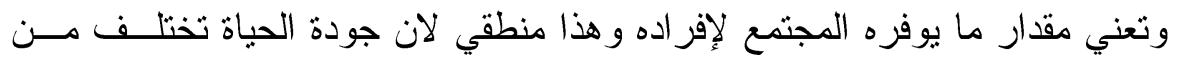

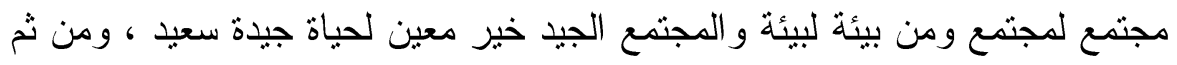

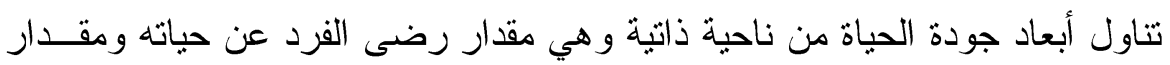

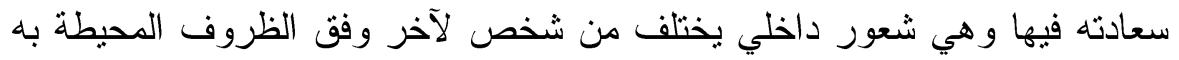

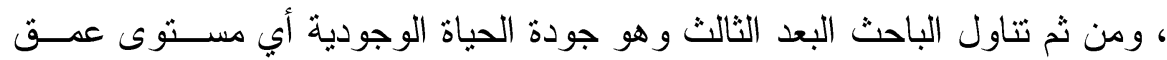

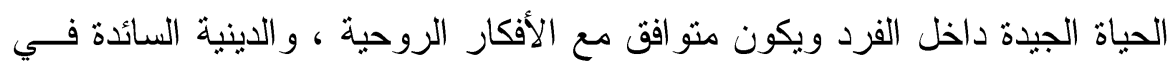

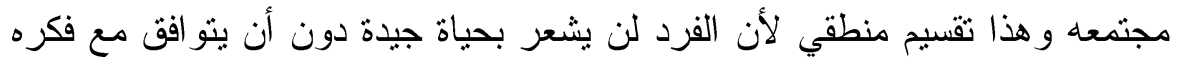

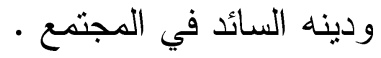

\section{جـ - مؤشر ات جودة الحياة}

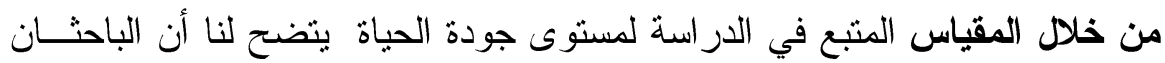

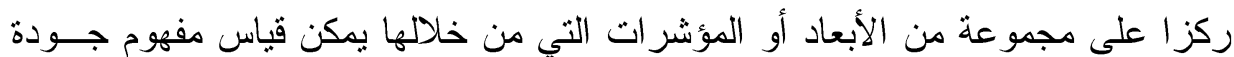

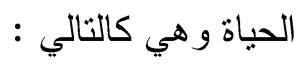

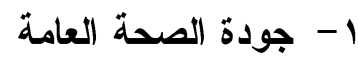

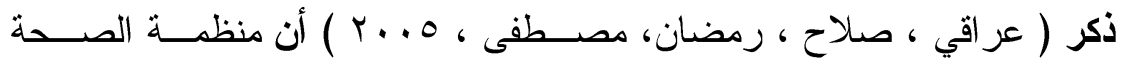

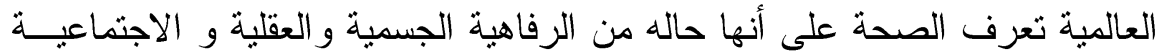
الكاملة وليس مجرد غياب المرض أو العجز بمعنى إلى أي حد يشعر الناس بـأنهم

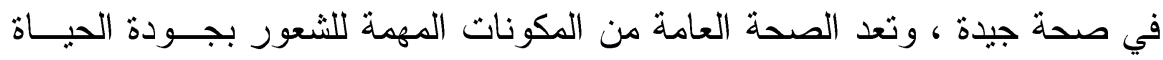

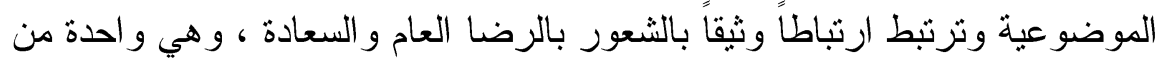

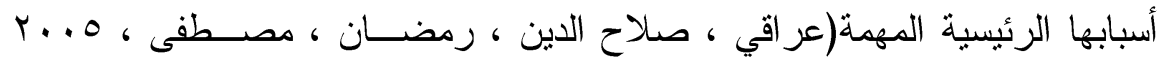

$$
\text { ( }(\varepsilon \vee \wedge-\varepsilon \vee \leqslant \text { : }
$$




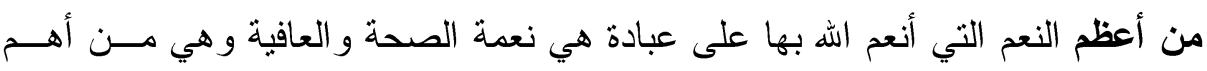

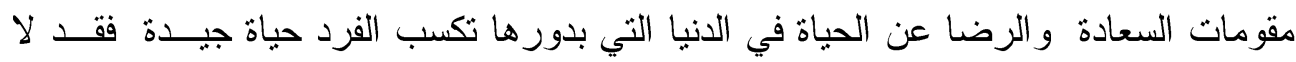

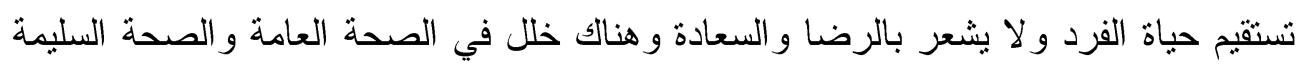

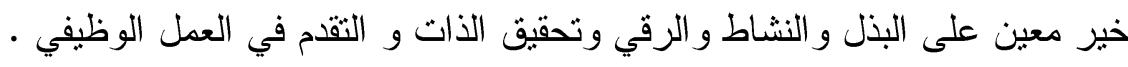
r بودة الحياة الأسرية و الاجنماعية.

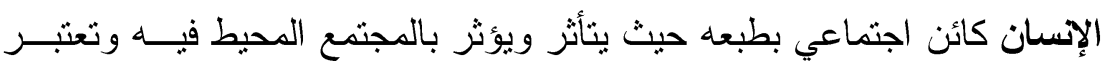

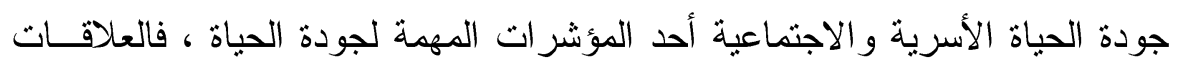

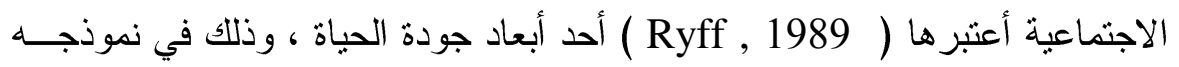
الثهير ذو الستة أبعاد لقياس جودة الحياة ( Ryff , 1989 , 971 ) .

يتضع مما سبق أن الأسرة هي المكون الرئبسي لشخصية الفرد خاصـــة فــي مرحلــة

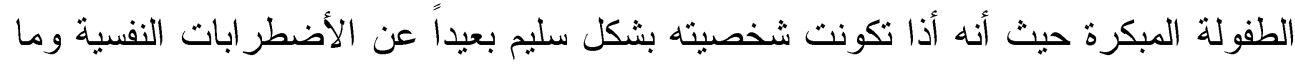

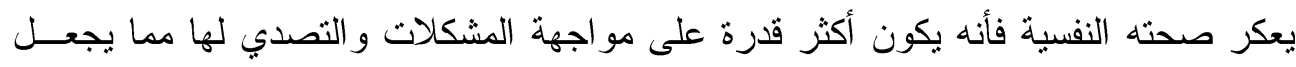

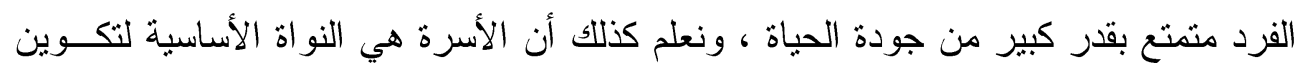

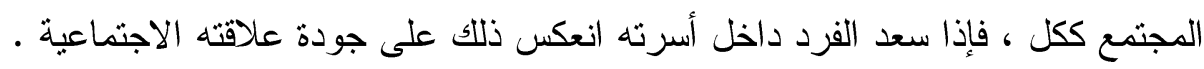

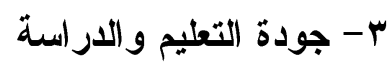

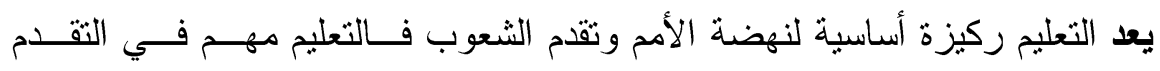
الاقتصادي الذي بدوره قد يسهم في حياة جيدة سليمة.

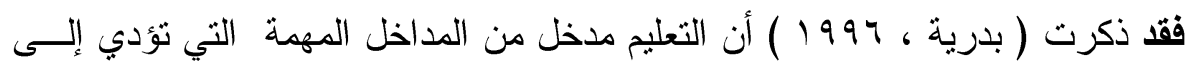

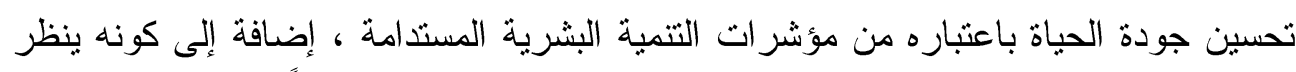

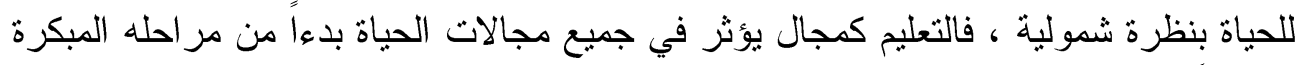

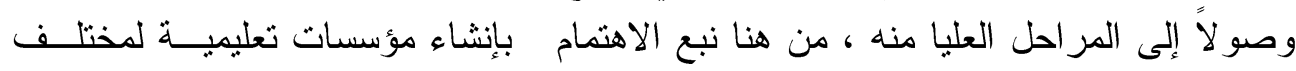

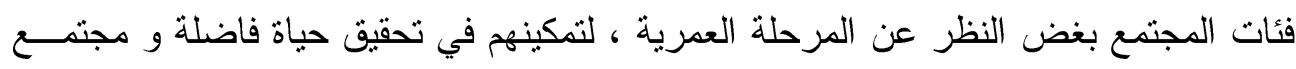

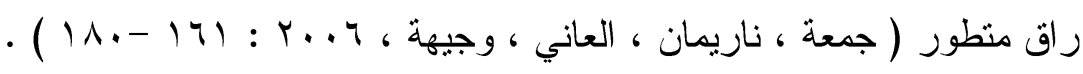

يعد التعليم و الدر اسة من أهم مقومات تطور الأمم وازدهار ها ولكي يشعر الفرد بالرضا

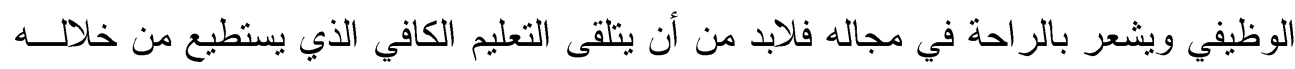


تطوير ذاته وتحقيق ذاته وليعيش بسعادة ويصل إلى مسنوى عال من جودة الحياة ، وكـــللك

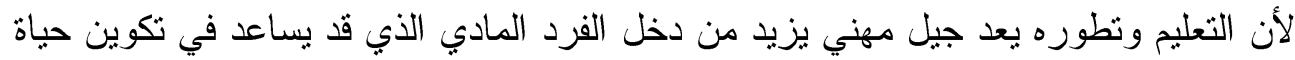

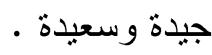

ع - جودة العواطف (الجانب الوجداني )

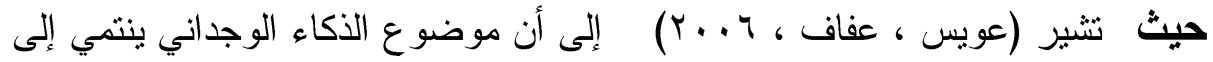

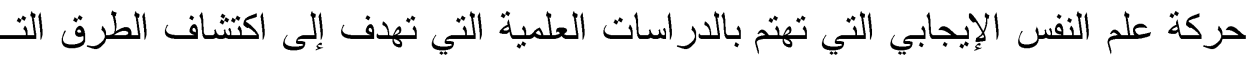

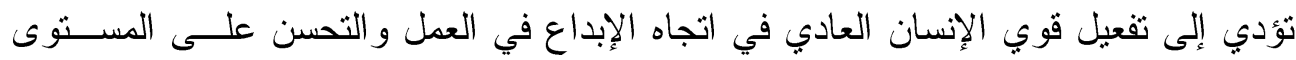

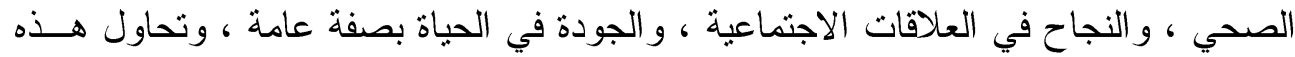

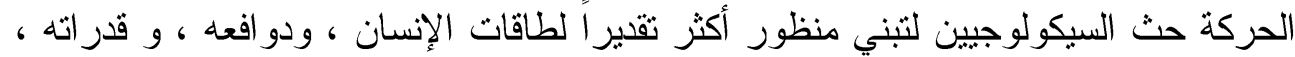

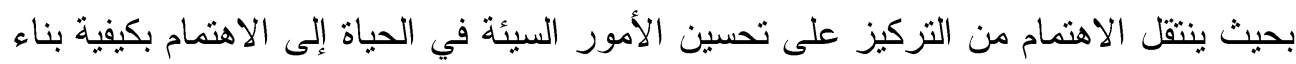

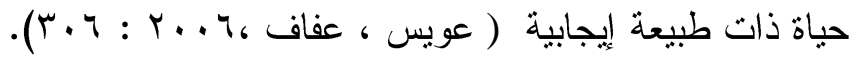

يتضح من البعد السابق أن العو اطف الوجدانية هي من المؤشرات الدالة على جودة الحباة

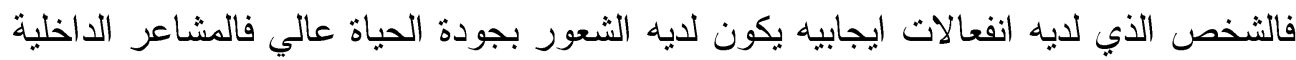

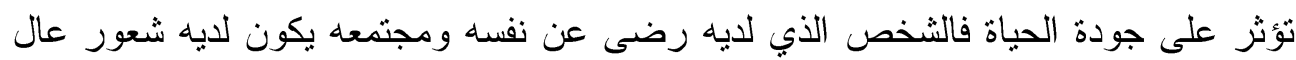

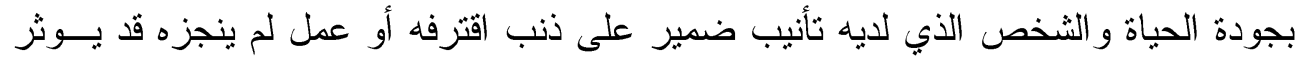

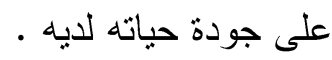

ه - جودة الصحة النفسية.

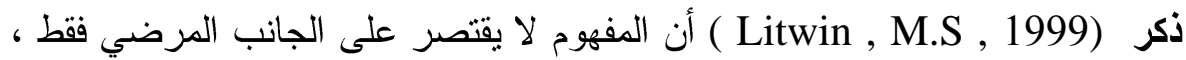

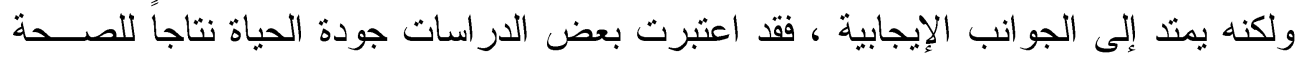

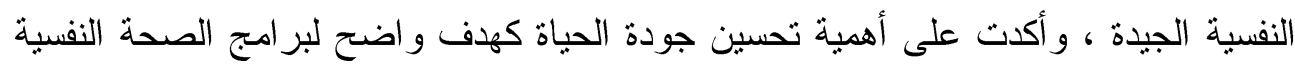

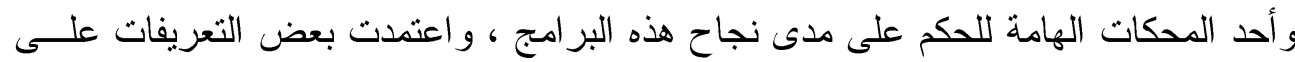

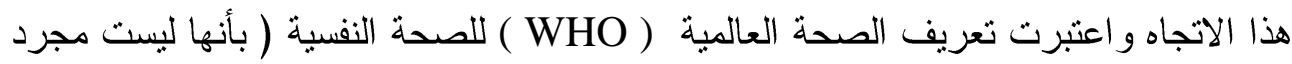

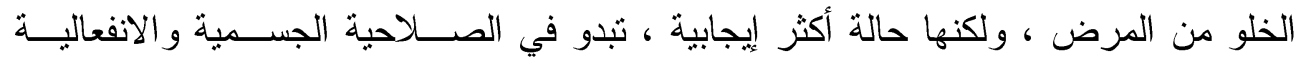

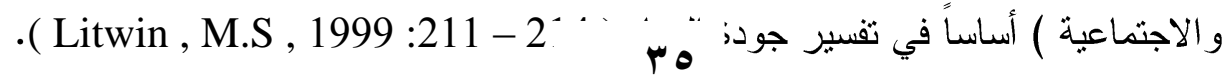

تعقيب .

يتضح مما سبق أن جودة الصحة النفسية تعتبر مؤشر مهم لجودة الحياة ، وهذا كـلام

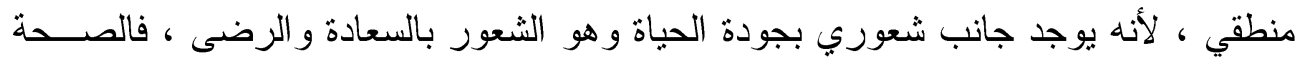


بصفة عامة عامل مهم في الثعور بالسعادة و الرضى عن الحياة ، و الصحة النفســـة بصــفة

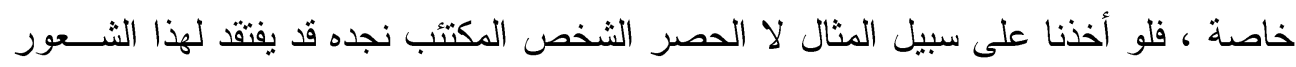

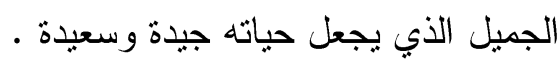
צ - جودة شغل الوقت و إدارته

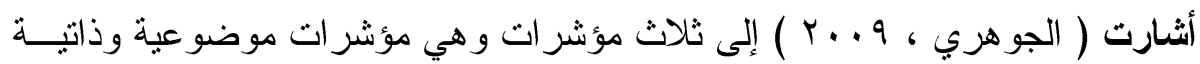

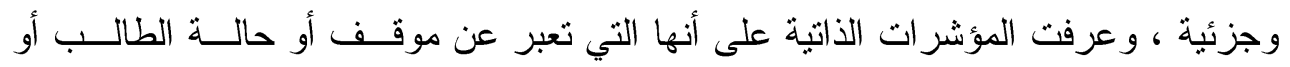

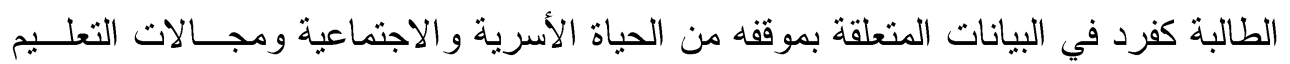

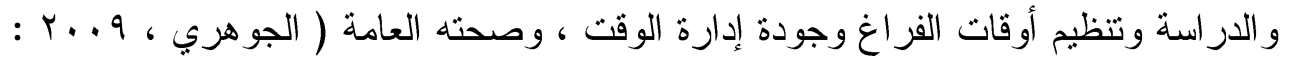

- ( $1 \leqslant 9$

تعقيب

يتضح من البعد السابق أن إدارة الوقت و الاستفادة منه يعتبر أحد مؤشر ات جودة الحبــاة

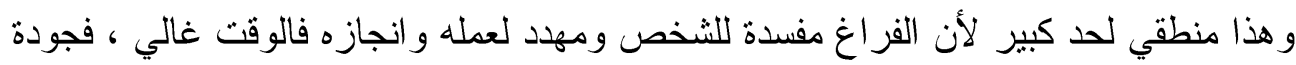

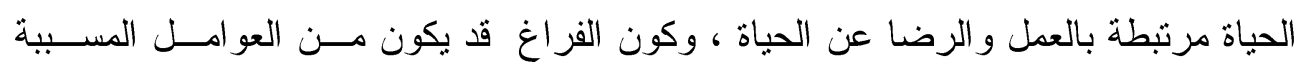

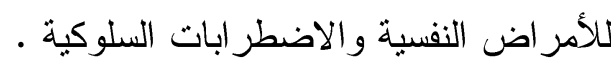
الار اسات السابقة المرتبطة بمتغير ات الاضبرات الدار استة:

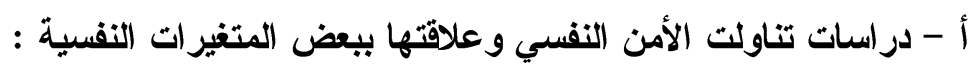

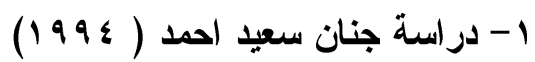

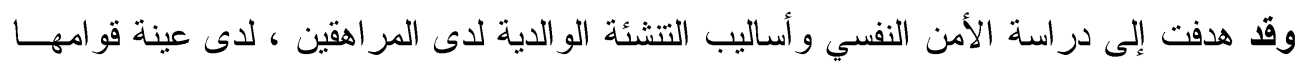

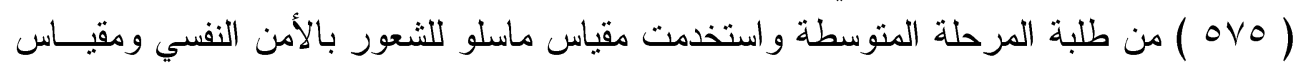

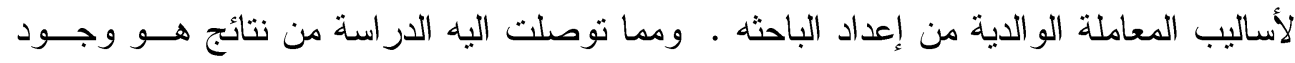

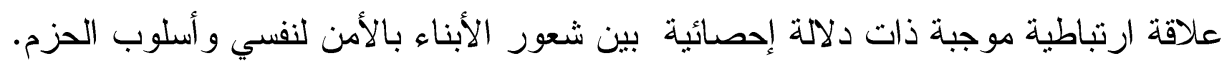

r

و قد هدفت إلى دراسة التصلب وعلافته بالثعور بالأمن النفسي لدى السيدات مرتفعات

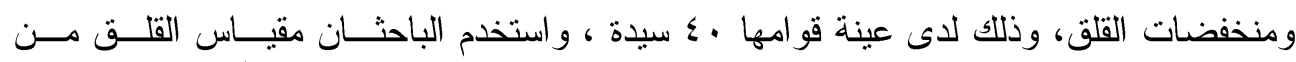

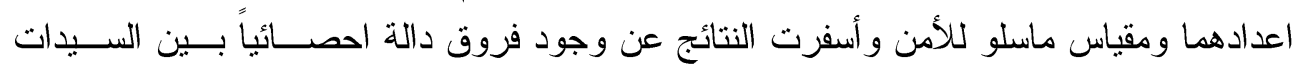

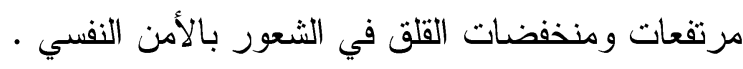

$$
\text { r }
$$

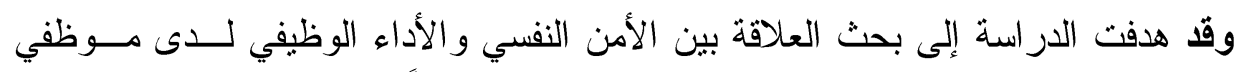

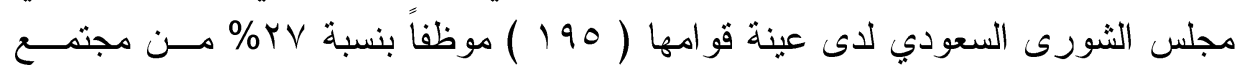

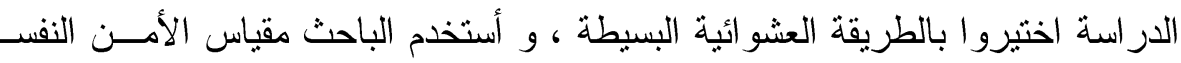


من اعداد ( الدليم و آخرون ، بو 199 ) ـ وكذللك مقياس التقييم الذاتي للأداء الوظيفي من

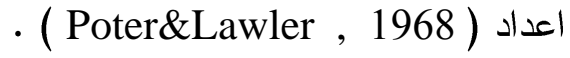
وقد قام القطان بترجمة هذا المقياس و استخدامه لتقبيم أداء الموظفين بدولة الكويت، وكان

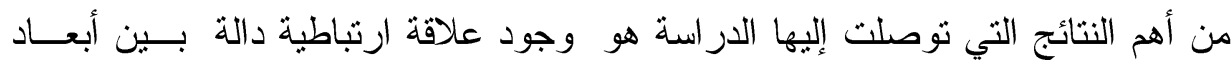
الأمن النفسي و الأداء الوظيفي الوتئ

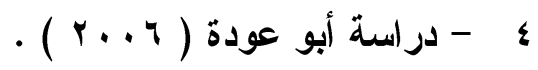

وقد هدفت لدر اسة بعض الاتجاهات السياسية و الاجتماعية و علاقتها بمستويات الأمن

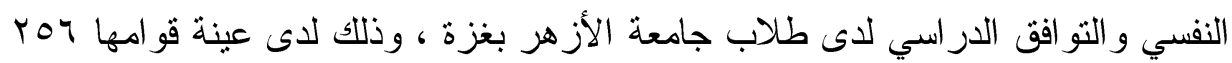

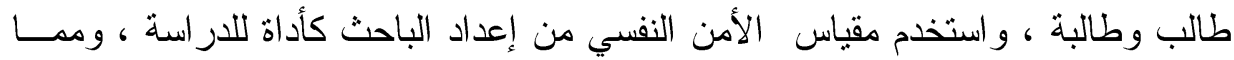

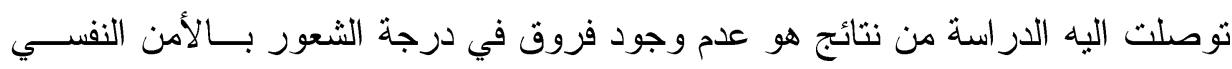

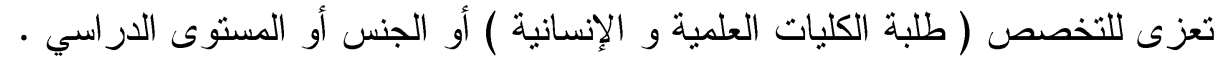

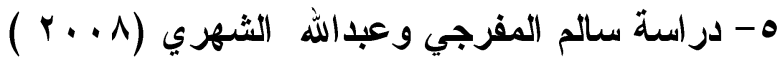

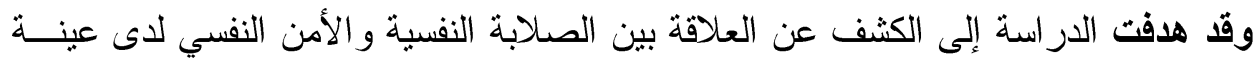

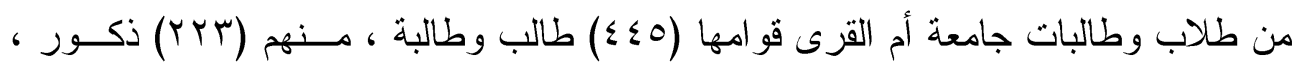

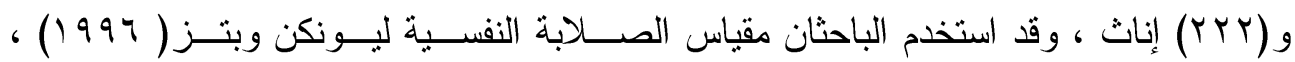

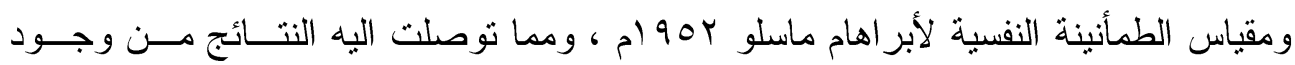

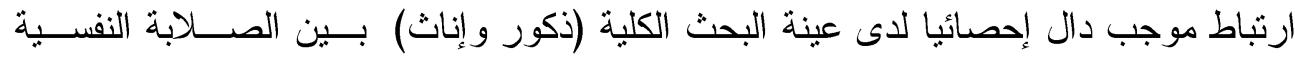

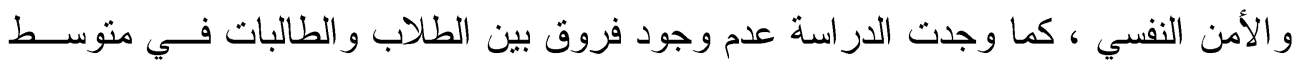

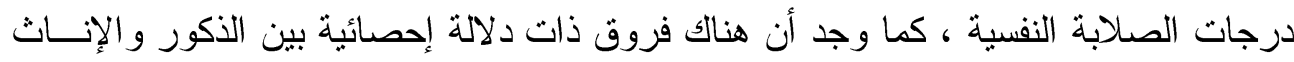
في الأمن النفسي لصالح الذكور .

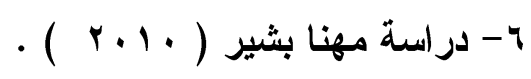

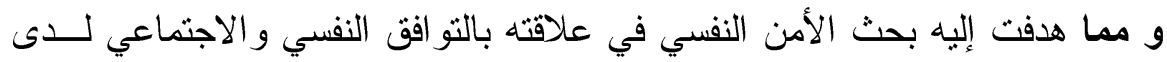

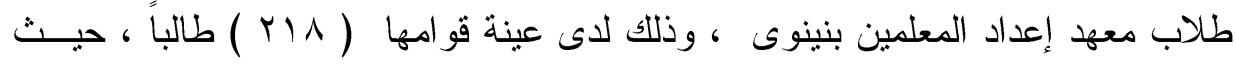

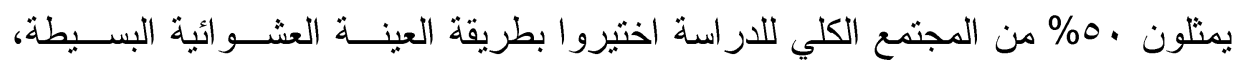

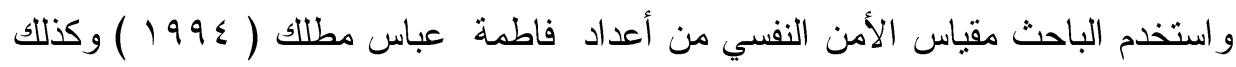

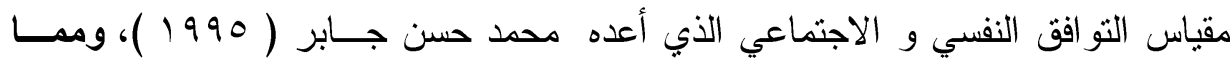

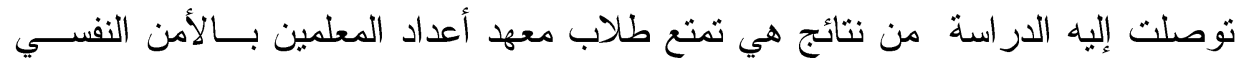




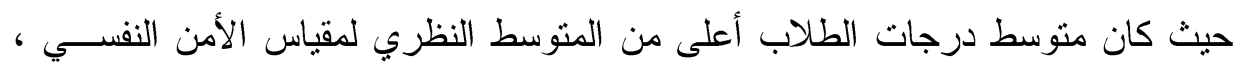

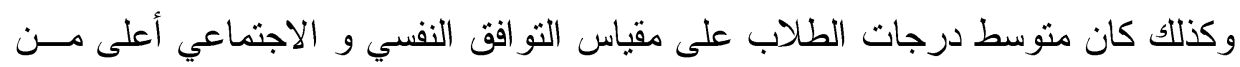

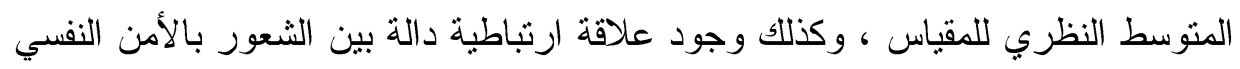

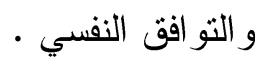

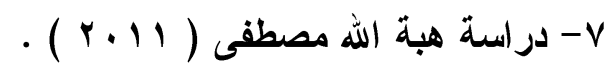

وقد هدفت لدر اسة الأمن النفسي و علاقته بأساليب المعاملة الو الدية كما يدركها الأبناء في

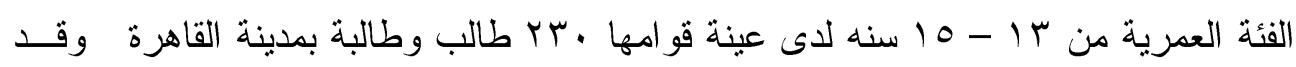

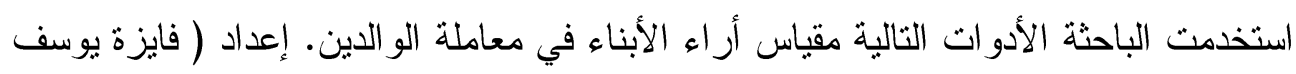

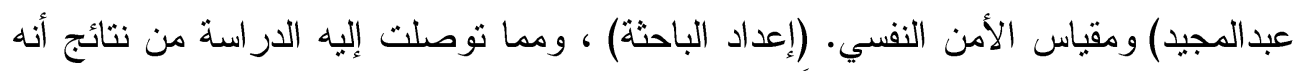

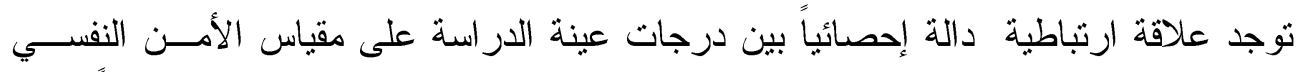

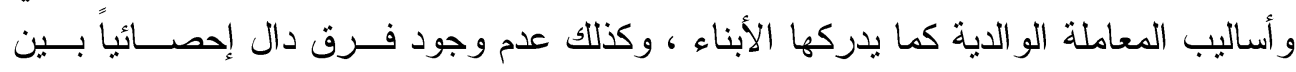

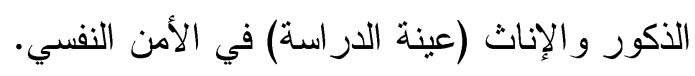

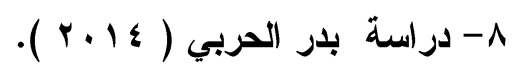

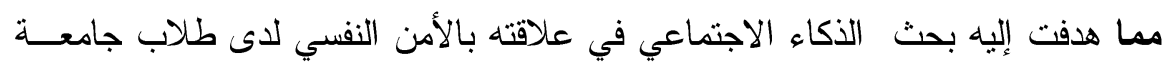

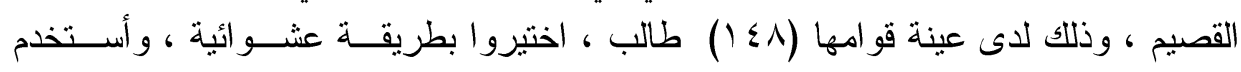

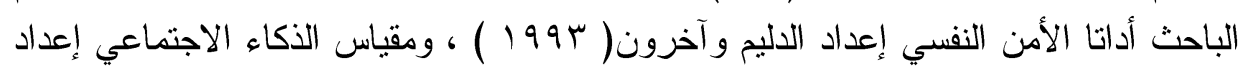

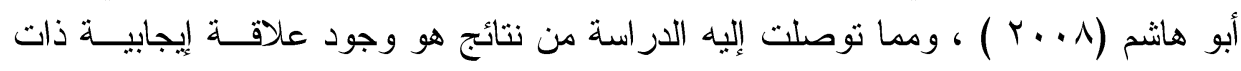

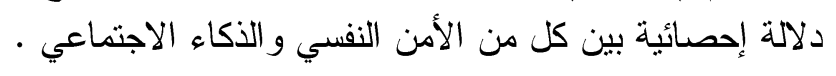

ب- دراسات تناولت الفروق بين الجنسين في الأمن النفسي •

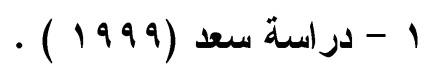

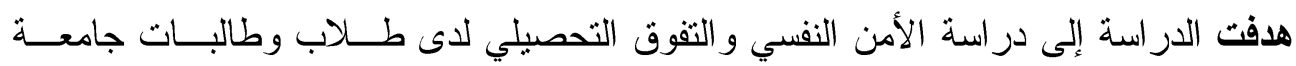

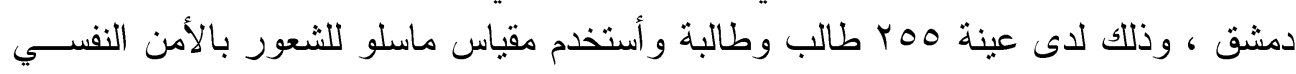

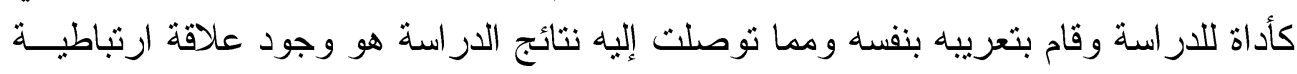

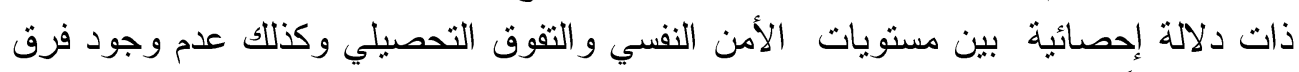

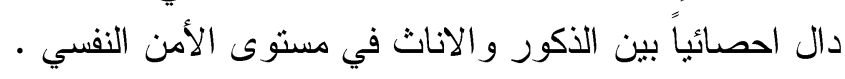

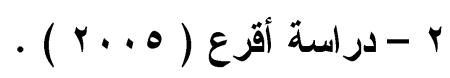

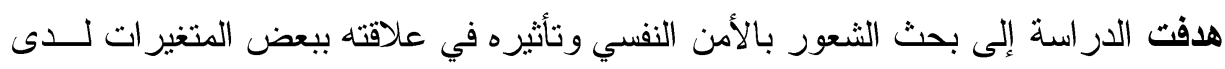

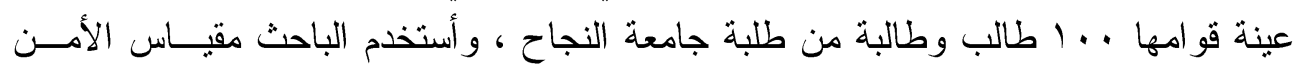




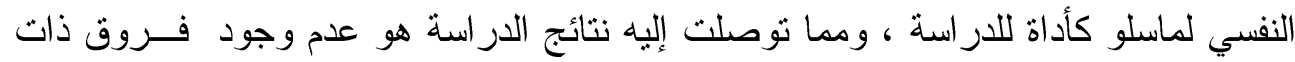

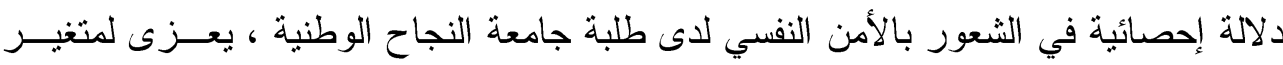

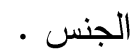

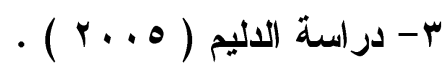

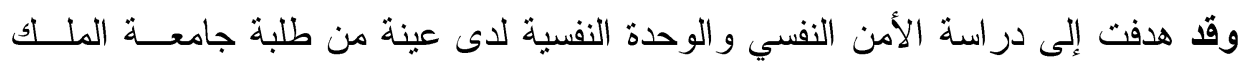

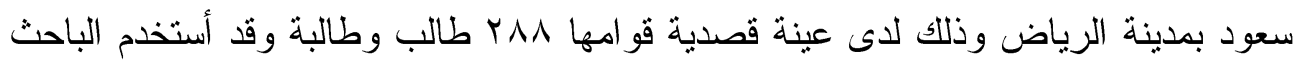

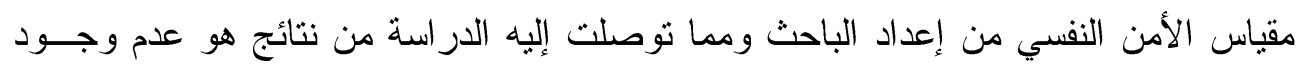

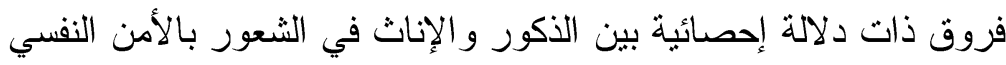

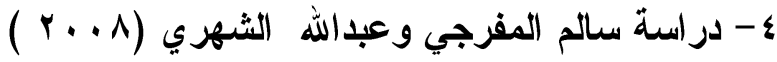

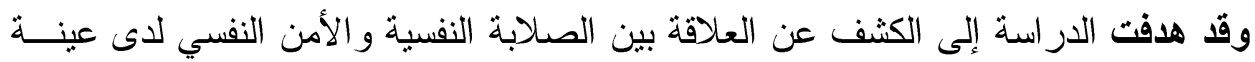

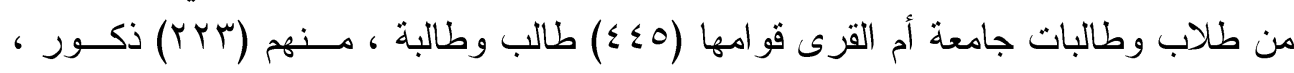

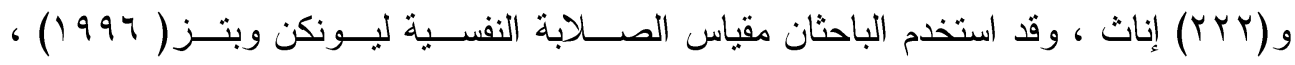

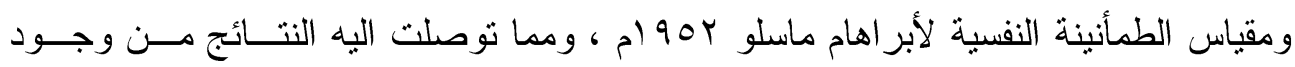

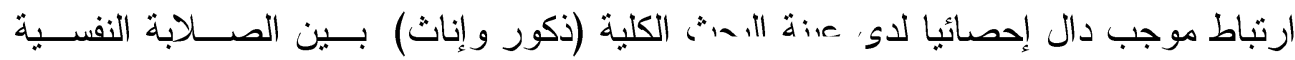

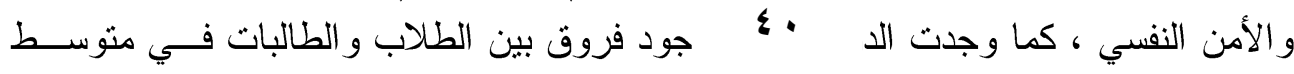
درجات الصلابة النفسية ، كما وجد أن هناك فروف ذات دلاتلة إحصائية بين الذكور و الإنــاث في الأمن النفسي لصالح الذكور •

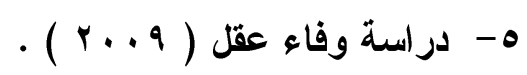

وقد هدفت إلى دراسة الأمن النفسي وعلاقته بمفهوم الذات لدى ألى المعاقين بصرياً بمحافظة

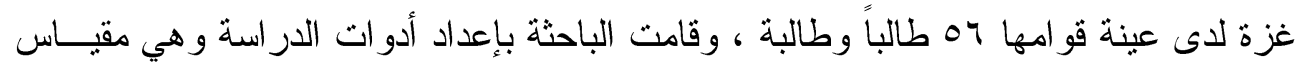

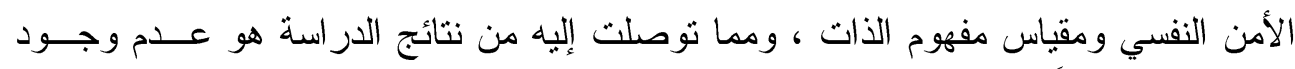
فرق دال إحصائياً بين الذكور و الإناث في مستوى الأمن النفسي. ومن الأهن

$$
\text { צ- دراسة هبة الله مصطقى ( } 11 \text { ـ ب ) . }
$$

وقد هدفت لدر اسة الأمن النفسي و علاقته بأساليب المعاملة الو الدية كما يدركها الأبناء في

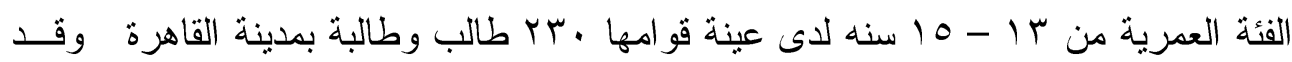

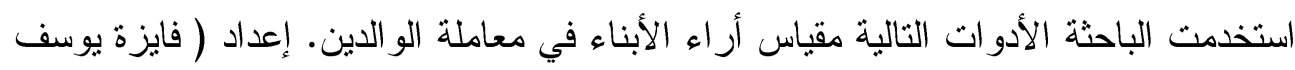
(د) ومقياس الأمن النفسي. (إعداد الباحثة) ، ومما توصلت إليه الدراسة من نتائج أنه ثوجد علاقة 
ارتباطية دالة إحصائياً بين درجات عينة الدر اسة على مقياس الأمن النفسي وأساليب المعاملة

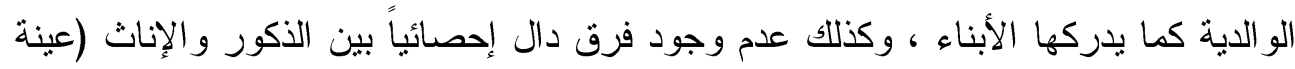
الدر اسة) في الأمن النفسي.

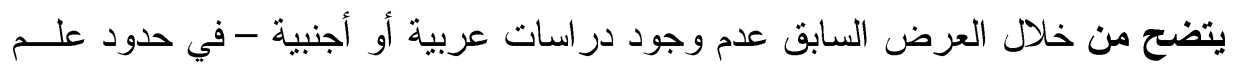

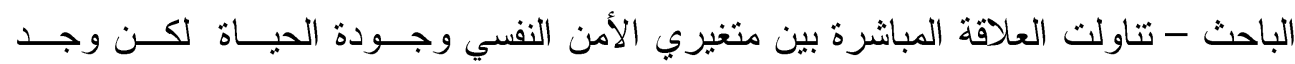

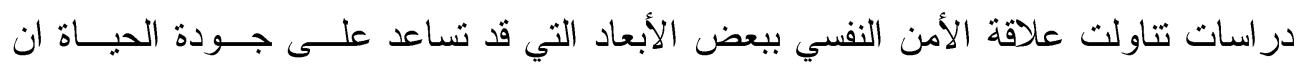

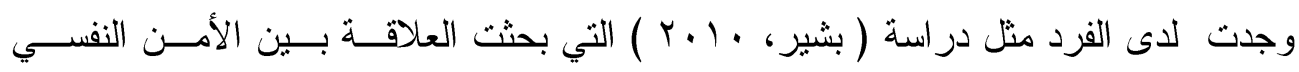
و النو افق النفسي و الاجتماعي وهي احد مقومات جودة الحياة.

\section{ثنانياً: فروض الدراسة :}

في ضو ء الإطار النظري و الدر اسات السابقة أمكن صياغة فروض الدر اسة كالتالي :

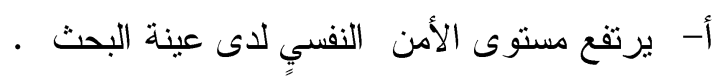
ب- لا يوجد فرق دال إحصائياً بين متوسطي درجات الذكور و الإناث على مقياس الأمــن ج - لا توجد علاقة ارتباطيه ذات دلالة إحصائية بين درجات الأمن النفسي ودرجات جودة

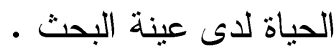

$$
\begin{aligned}
& \text { إجراعات الدراسة: }
\end{aligned}
$$

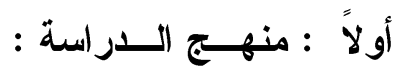

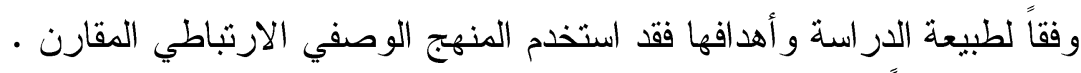

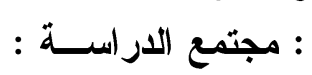

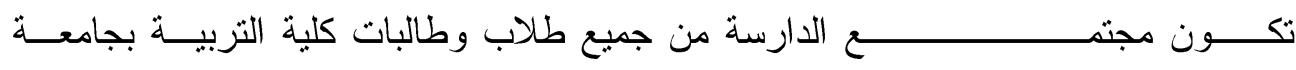

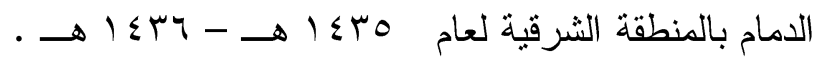

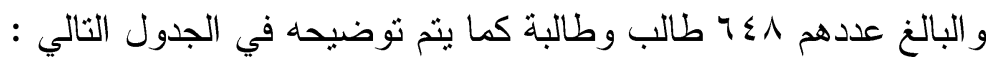
جدول (1) مجتمع الدر اسة حسب الجنس و التخصص

السنة التحضصيرية




\begin{tabular}{|c|c|c|c|}
\hline $1 \wedge \varepsilon$ & 14 & $9 \wedge$ & الدر اسات الإسلامية \\
\hline$Y \leq \Lambda$ & rᄉl & YYV & المجموع \\
\hline
\end{tabular}

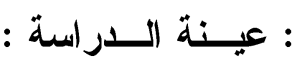 ثالث \\ أ- أعينة الاستطلاعية :}

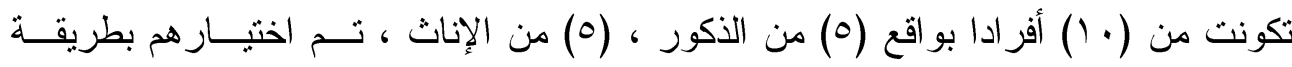
عشو ائية ، وذلك للتحقق من صدق وثبات أداتا الدر اسة.

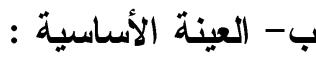
تكونت من ( . (1 ) طالباً وطالبة من مرحلة البكالوريوس بكلية الثربية جامعة الدمام ، مسنـ

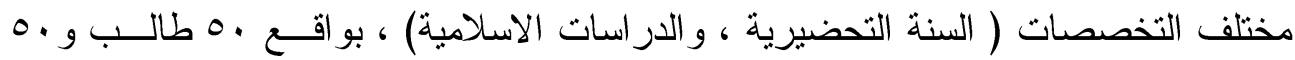

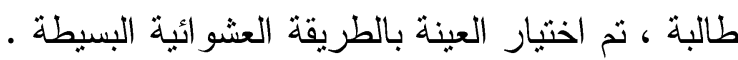

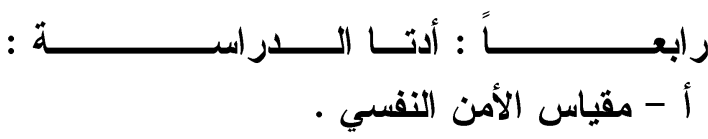

أستخدم الباحث مقياس الطمأنينة النفسية من ضمن سلسة مقاييس مستشفى الصــــة النفسـية

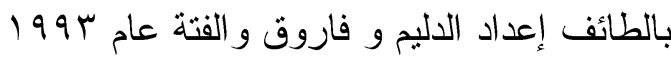

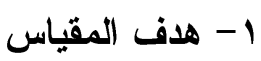

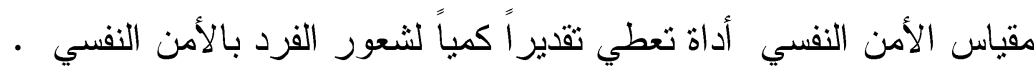

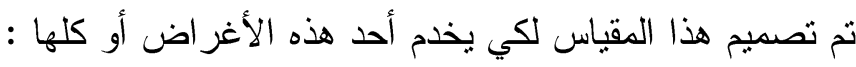

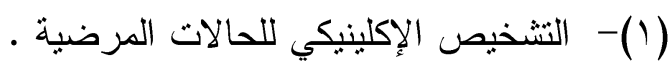

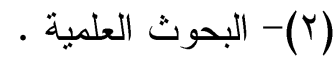

(Y) - الدر اسات و البحوث التي تثكل بالأمن النفسي سواء في صورة المرضية أو السوية .

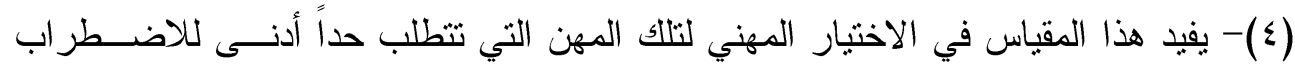

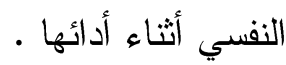

r

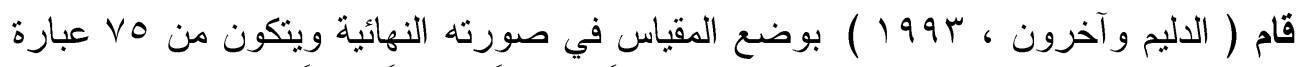

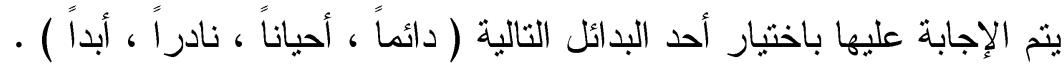

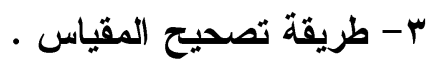




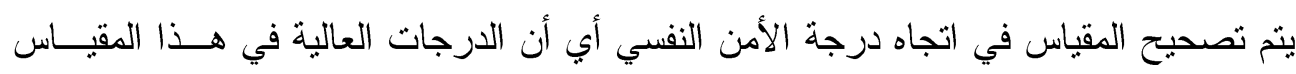

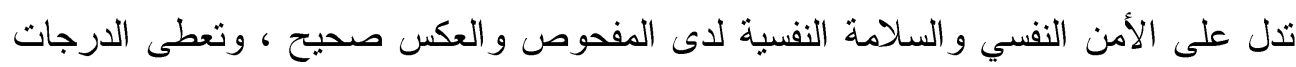

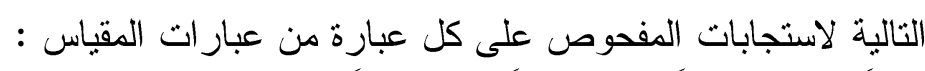

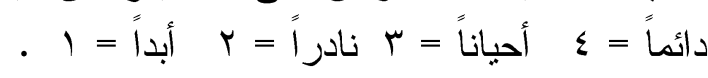

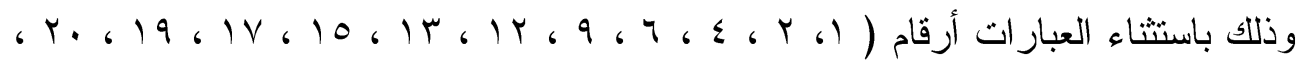

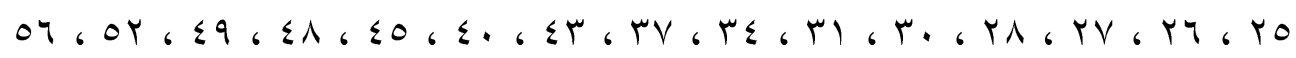
، ،

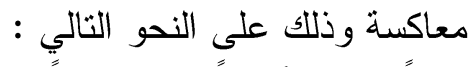

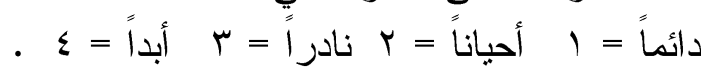

ع - ثبات و صدق المقياس

(أ) - الثبات

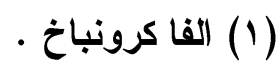

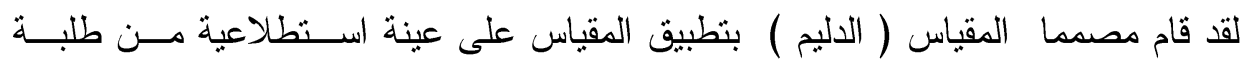

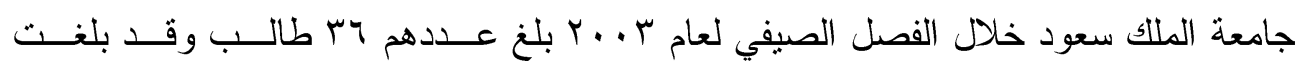

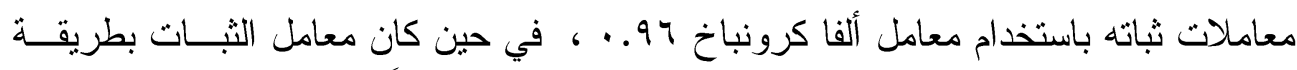

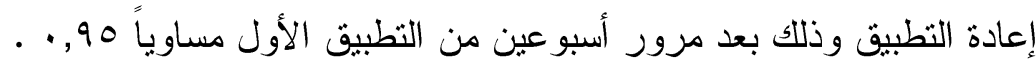
: (r)

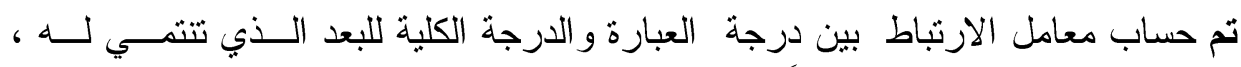

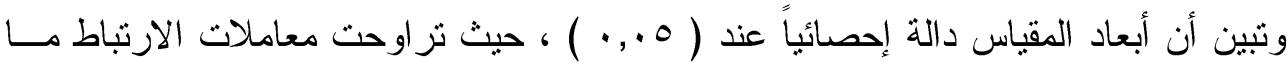

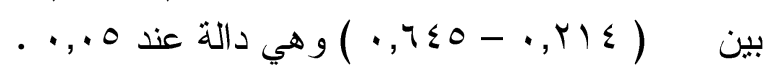

$$
\text { (ب)- الصدق ( صدق البناء) : }
$$

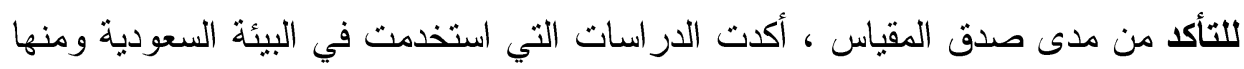

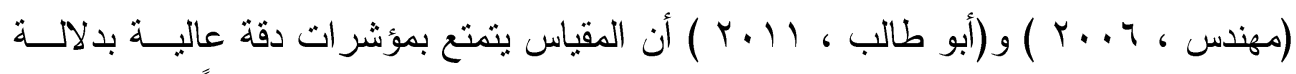

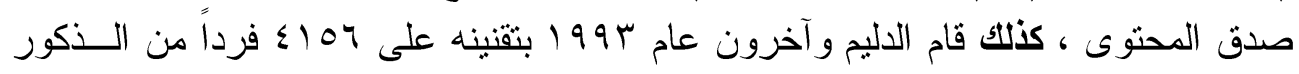

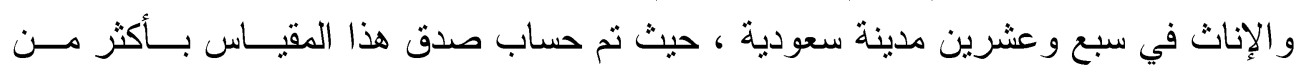
طريقة(صدق المحكمين ، الصدق العاملي ، الصدق الذاتي ، الصدق الظاهري) ، مدئة

( ) - الصدق و الثبات في الار اسة الحالية 


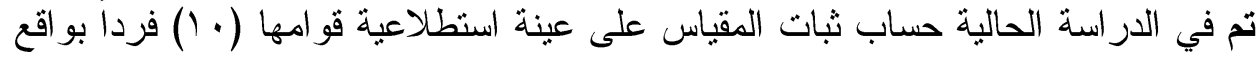

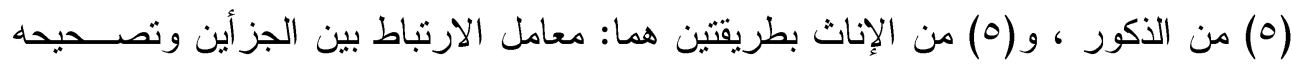

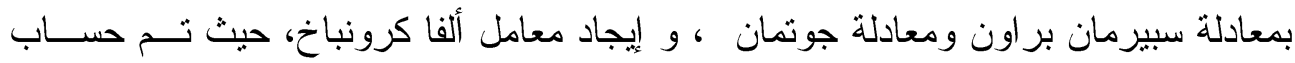

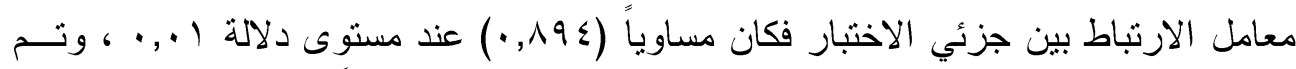

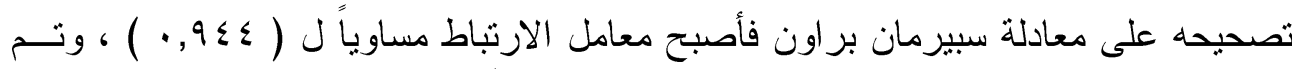

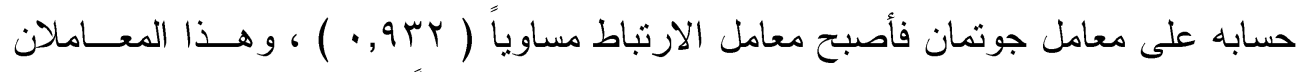

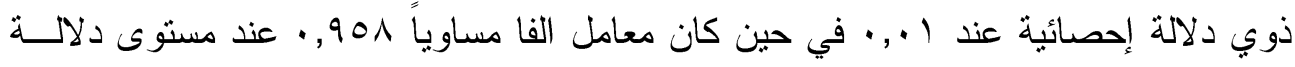

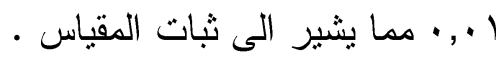

(r)

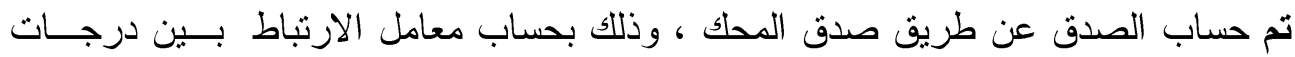

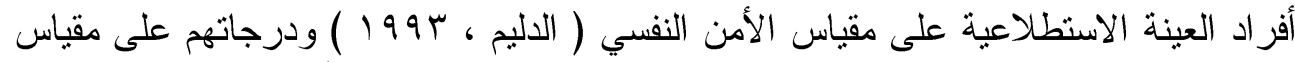

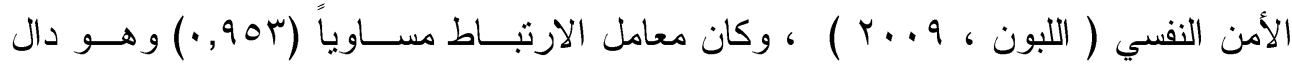

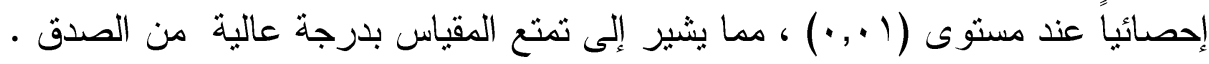
ب- مقياس جودة الحياة

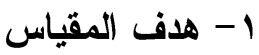

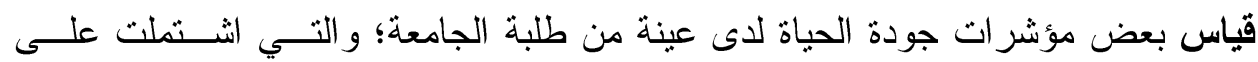

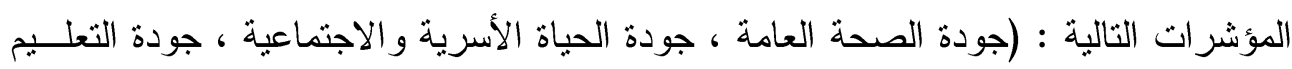

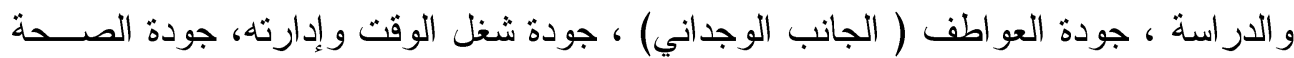
(النفسية )

\section{r - محتوى وطريقة تصحيح المقياس}

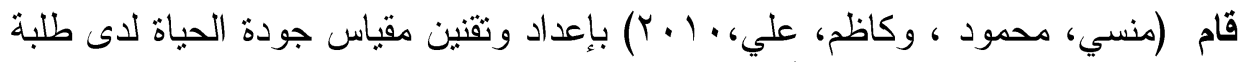

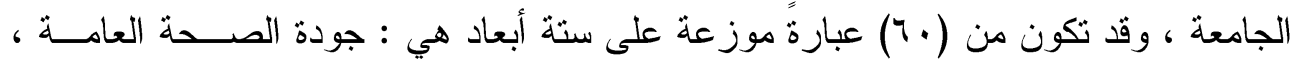

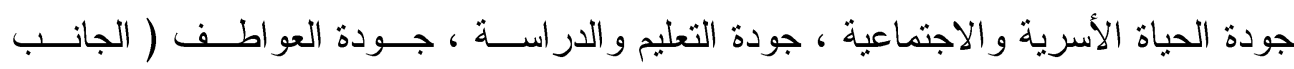

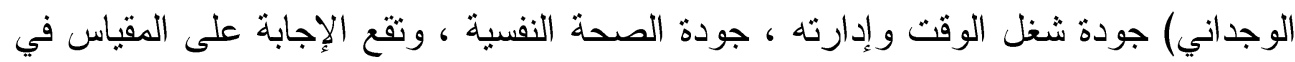

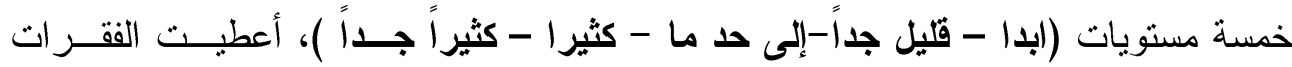

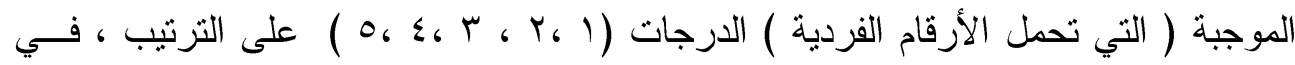

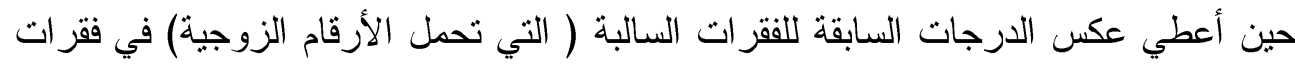
المقياس ، حيث يشير ارتفاع الدرجة إلى زيادة الإحساس بجودة الحياة . 
ب - صدق وثبات المقياس (أ) - الثبات

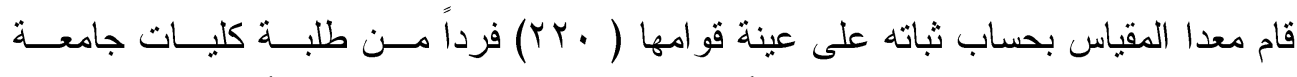

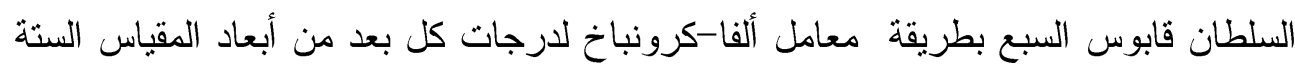

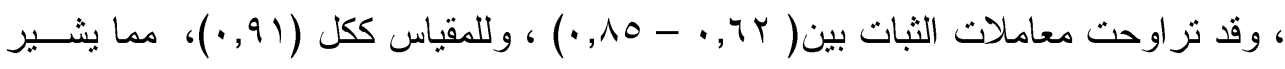
إلى ثبات المقياس.

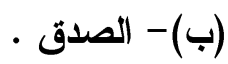

تم حساب صدق المقياس بطريقتين هما:

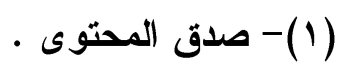

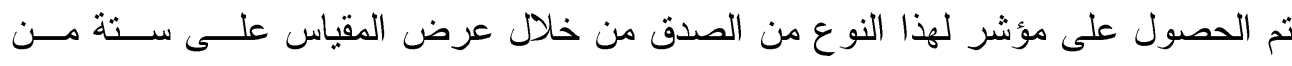

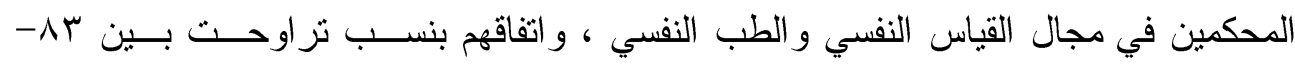

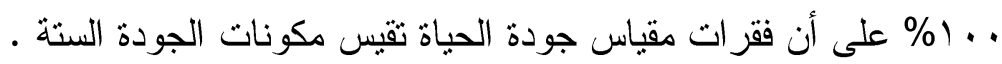

(r) - الصدق المرتبط بمحك وذلك بحساب معامل الارتباط بين درجات أفراد العينة الاستطلاعية على مقياس جودة الحياة

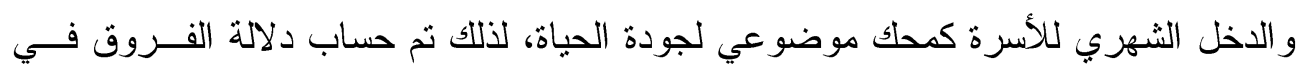

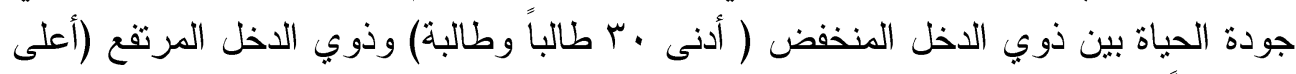

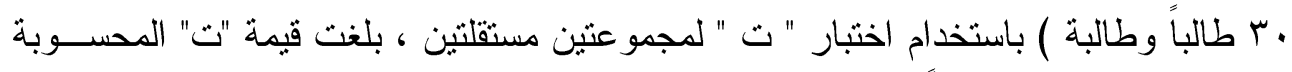

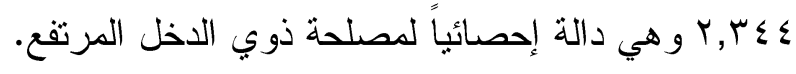

( ( ) - الصدق و الثبات في الار اسة الحالية : (أ ) (أثبات

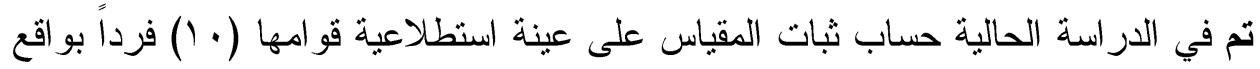

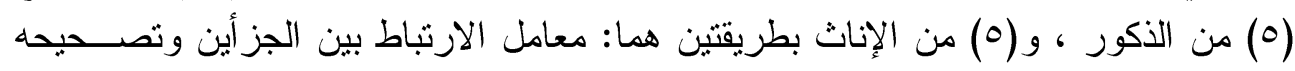

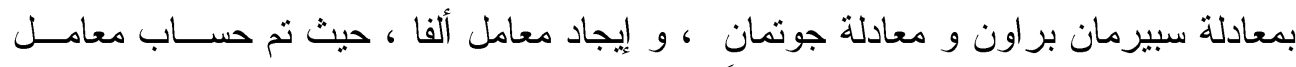

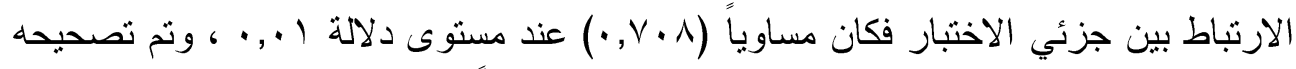

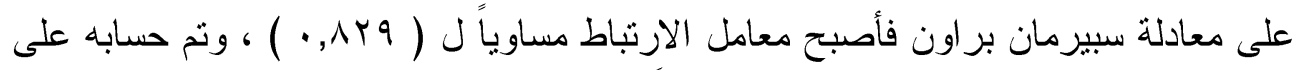

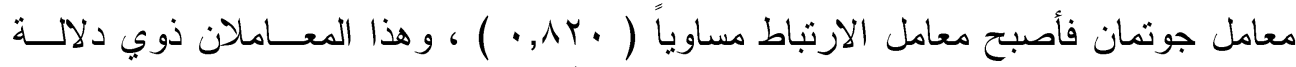

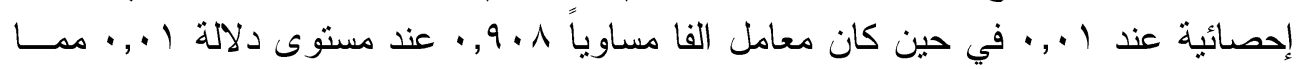

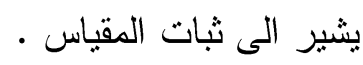


تم حساب الصدق عن طريق الصدق المرتبط بالمحك ، وذللك بحساب معامل الارتبـــاط بـين

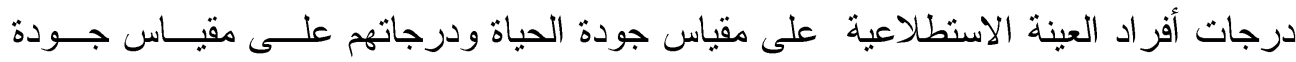

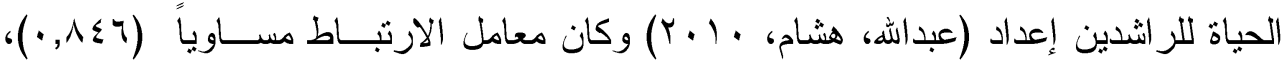

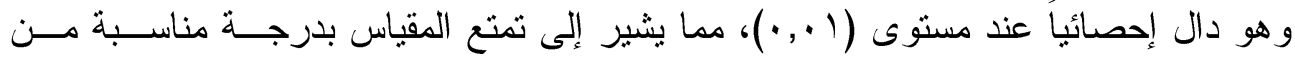

$$
\text { خامساً - الأساليب الإحصائية }
$$

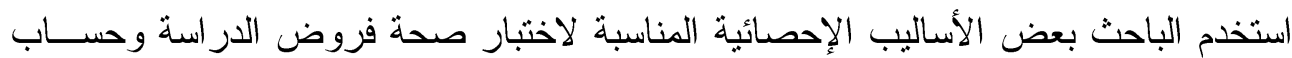

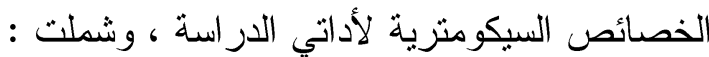
أ- معاملات الارتباط.

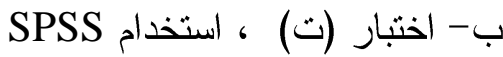

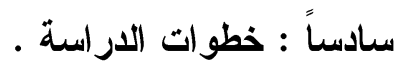
تمثلث الخطو ات الإجر ائية للار اسة فية الإسية

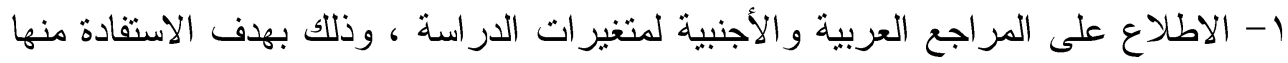
في كتابة الإطار النظري. ץ- الاطلاع على الدر اسات السابقة المرتبطة بمتغير ات الدراسة و الاستفادة منها في صـيّاغة الفروض. ب- حساب الصدق و الثبات لأداتا الدراسة ، وذلك من خلال تطبيقهما على عينة اســطلاعبة من طلبة كلية التربية جامعة الدمام. ع- تطبيق مقياس الأمن النفسي ، ومقياس جودة الحياة على أفر اد العينة الأساسية من طلبـــة كلية التربية جامعة الدمام.

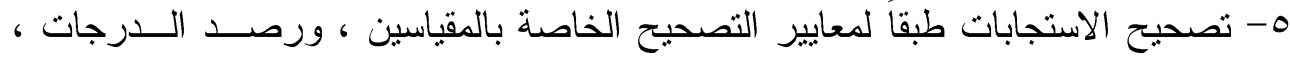

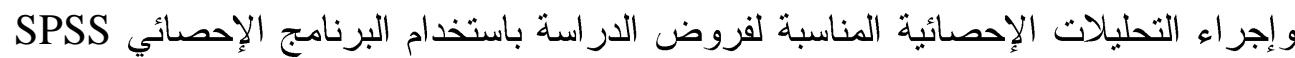

צ-تفسير ومناقشة النتائج و التحقق من صحة فروض الدراسة.

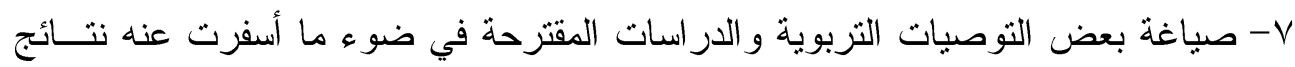

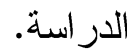




\section{نتائج الار اسة وتفسير اتها:

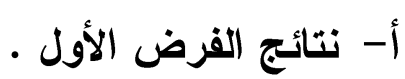

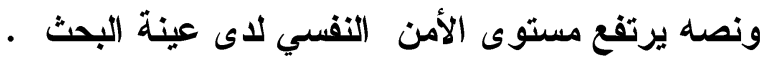

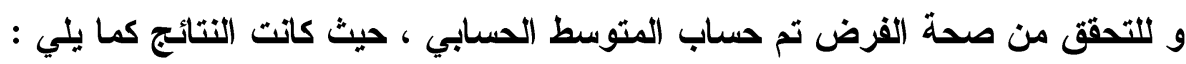

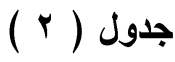

المتوسط الحسابي والاتحر اف المعياري للأمن النفسي لادى عينة من طلة جامعة الدمام .

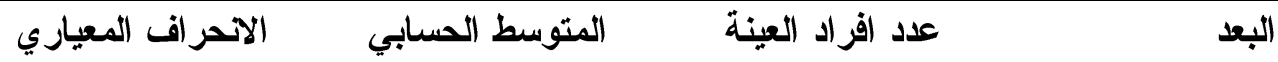

\begin{tabular}{|c|c|}
\hline Y & $r \mid \wedge, r$ \\
\hline
\end{tabular}

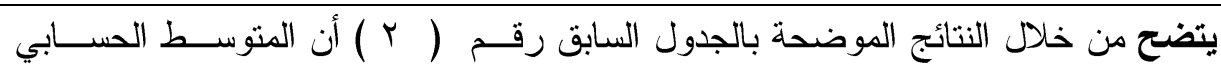

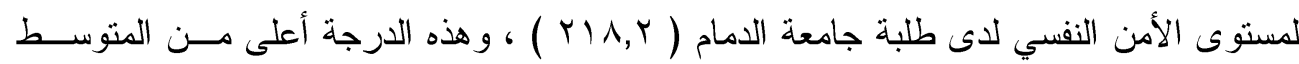

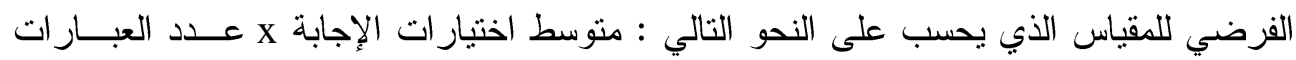

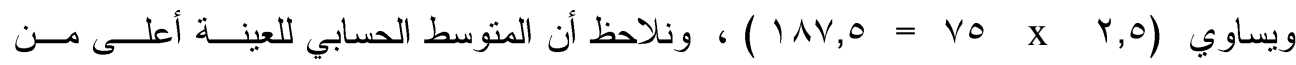

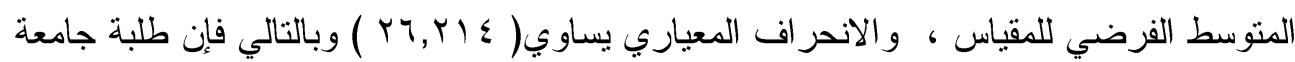

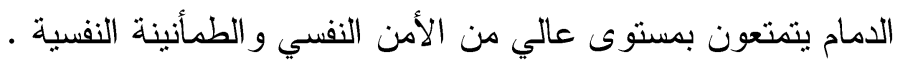

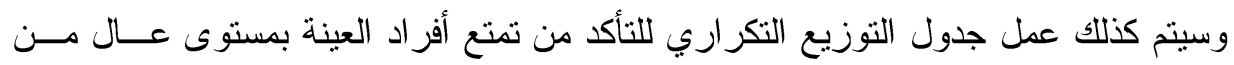

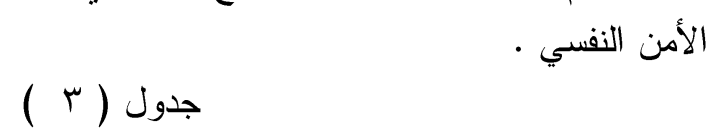

\begin{tabular}{|c|c|c|c|c|c|}
\hline عـكــد & الفئة & عدد التكر ار & الفئة & عدد التكرار & الفئة \\
\hline V & $($ YY.-Y01) & 0 & $(Y) \cdot-r \cdot 1)$ & . & $\left(10 .-v_{0}\right)$ \\
\hline . & $(Y V \cdot-Y Y))$ & ir & $\left(Y r_{\cdot}-Y_{1}\right)$ & 1 & $(1 \mathrm{~V} \cdot-101)$ \\
\hline$\varepsilon$ & $(Y \wedge \cdot-Y \vee \backslash)$ & 19 & $(Y r \cdot-Y Y))$ & 1 & $(|1,-| v \mid)$ \\
\hline . & $\left(r_{q} \cdot-r_{\Lambda}\right)$ & 7 & $(r \leq \cdot-r M)$ & rr & $(19 .-111)$ \\
\hline . & $(r \ldots-r q))$ & $1 \varepsilon$ & $\left(Y_{0} .-Y \leq 1\right)$ & 9 & $(r \ldots-191)$ \\
\hline
\end{tabular}


يتضح كذلك من جدول التوزيعات التكرارية السابق ( جدول رقم ب ) أن أفراد عينة الدراسة

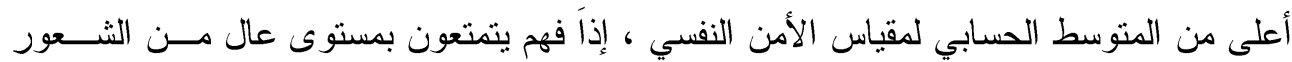
للأمن النفسي ، وقد يرجع ذلك للأسباب التالية:

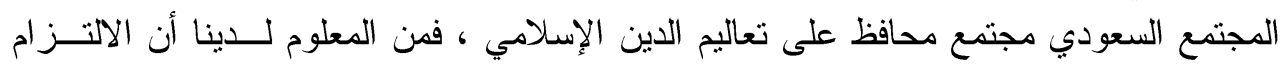

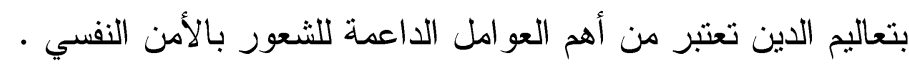

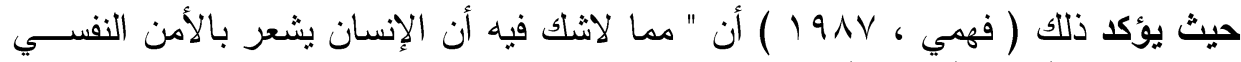

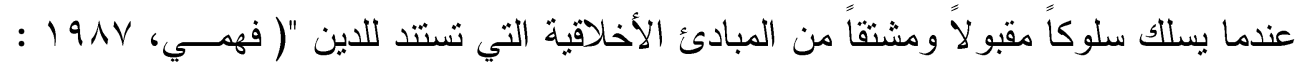
(r) (Y)

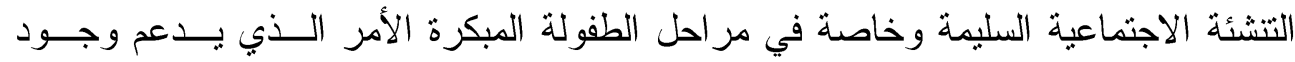

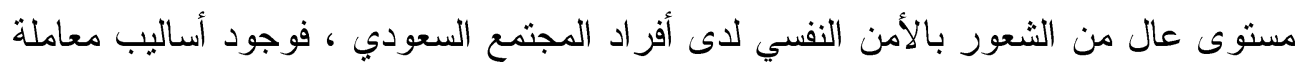

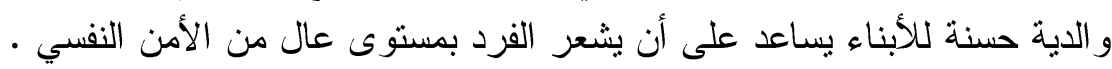

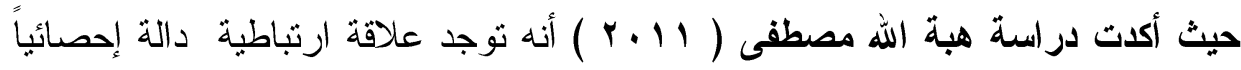

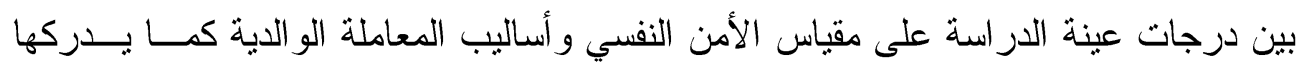
الأبناء. أن الفئة المستهدفة بالدراسة قد أثبعت لهم الحاجات الفسيولوجية مما بساعدهم على القــدرة

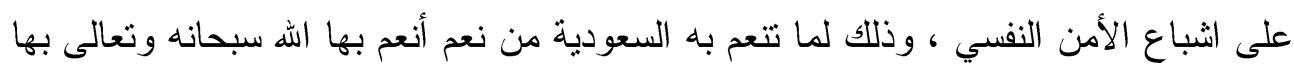

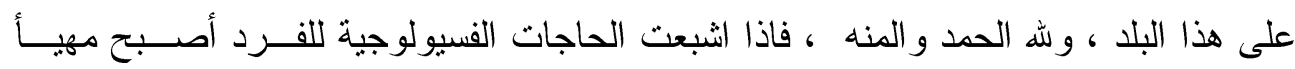

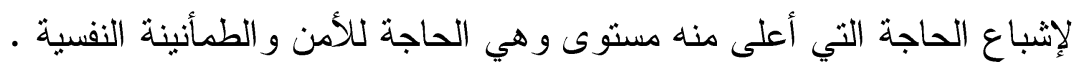

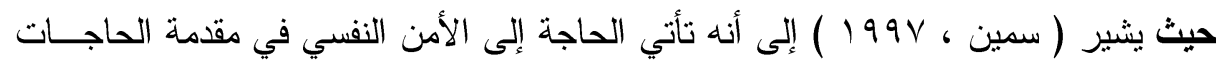

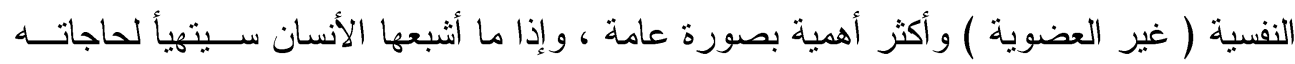

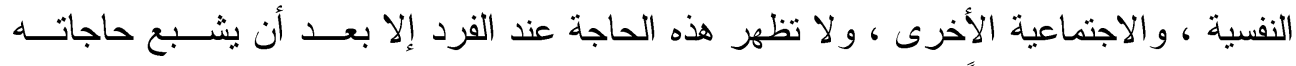

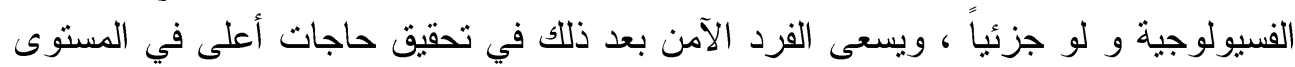

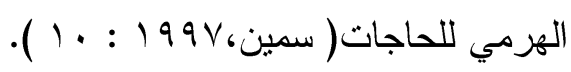

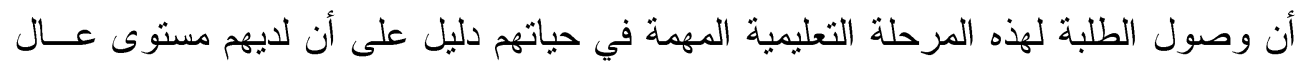

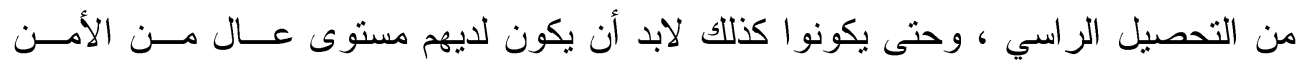

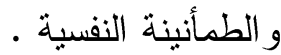

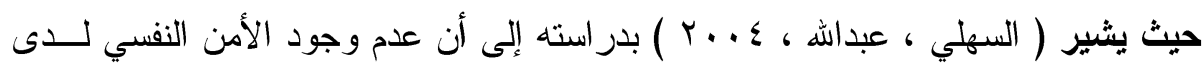

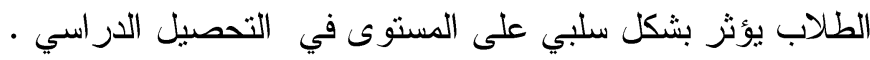

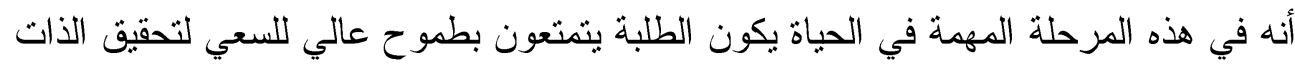

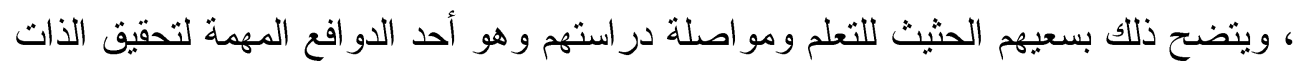


، فهذه الحاجة لا تتحقق الا اذا أشبعت الحاجات الأقل مسنوى منه _كما في الثكل رقم ( )

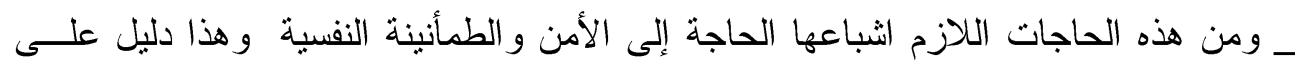

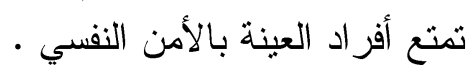

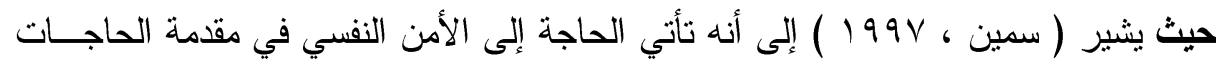

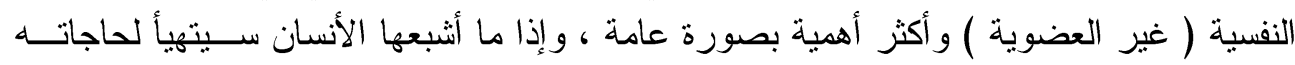

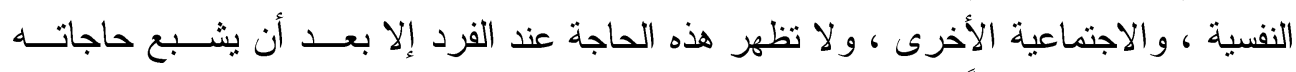

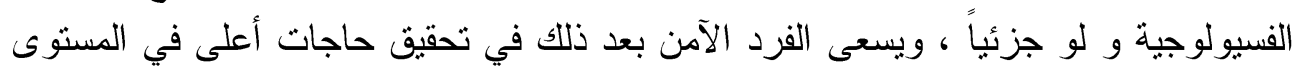

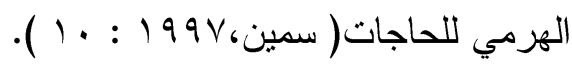

$$
\begin{aligned}
& \text { ب - نتائج الفرض الثاني : }
\end{aligned}
$$

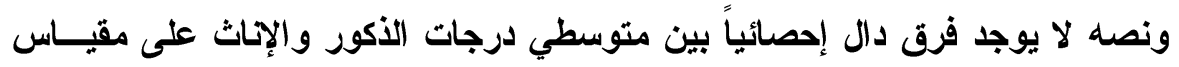

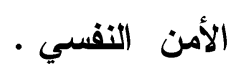

وللتأكد من صحة الفرض السابق سيتم حساب اختبار ( ت ) " T-test بين متوسطي درجات

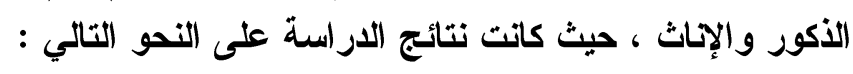

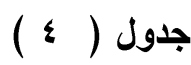

\begin{tabular}{|c|c|c|c|c|c|}
\hline مسلالة & 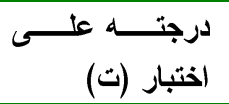 & الحسابي & عدد أفراد العينة & الجنس & المتغير \\
\hline \multirow{2}{*}{ VII, } & \multirow{2}{*}{$r, \leqslant q \varepsilon$} & r Y & 0. & ذكور & الأمن النفسي \\
\hline & & $r .9,0 r$ & 0 . & اناث & الأمن النفسي \\
\hline
\end{tabular}

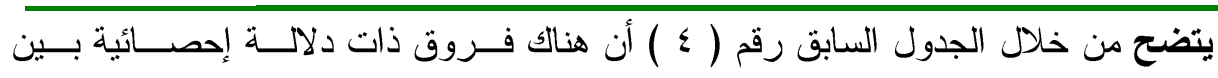

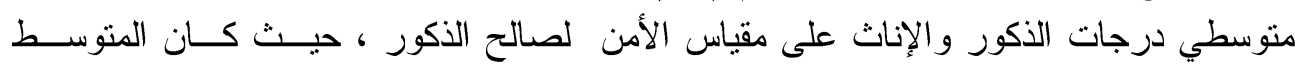

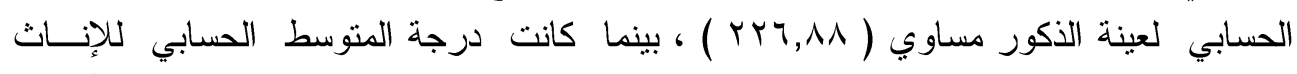

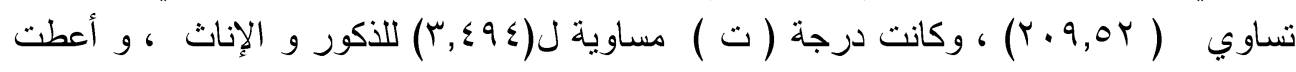

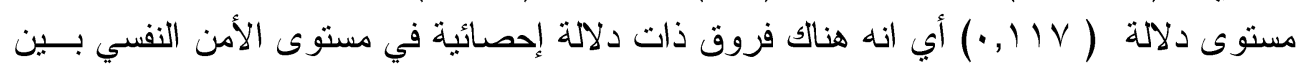

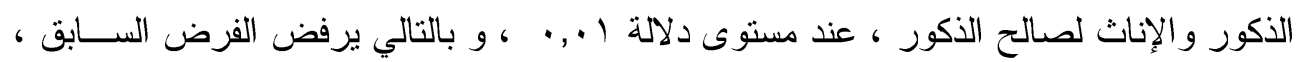

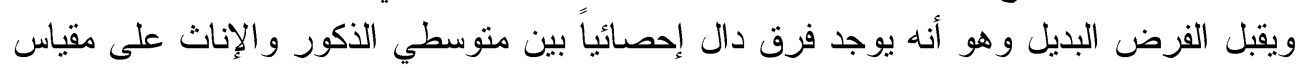

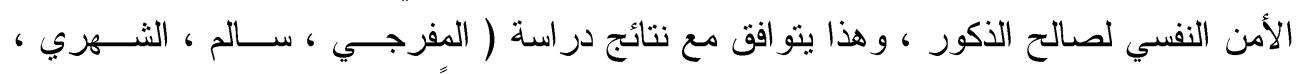

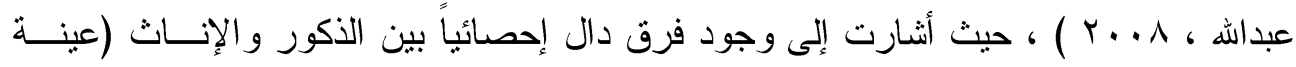

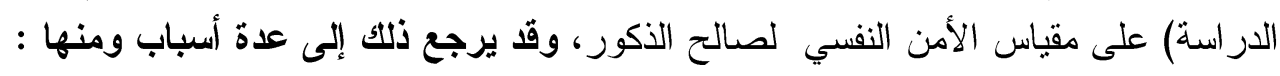


قد يرجع ذلك الى طبيعة المر أة والرجل ، فالرجل يكون أكثر قدرة علــى تحمـل الأعبــاء

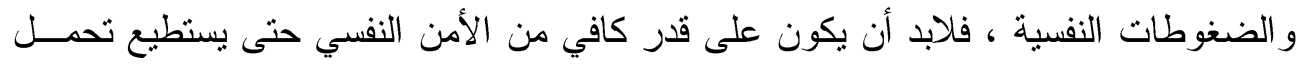

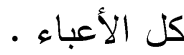

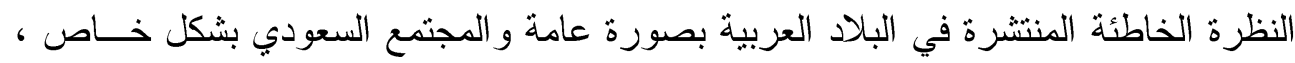

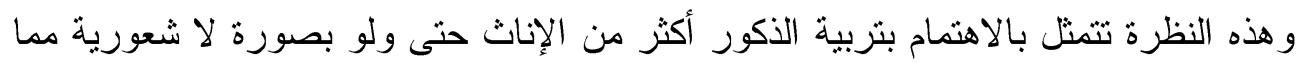

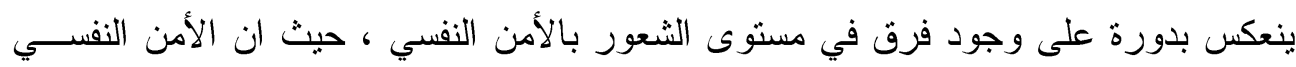

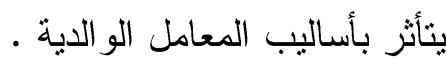
حيث أكدات دراسة هبة الله مصطفى ( 11 ـ ب ) أنه نوجد علاقة ارتباطية دالة إحصائياً بين درجات عينة الدر اسة على مقياس الأمن النفسي و أساليب المعاملة الو الدية كما بدركها الأبناء.

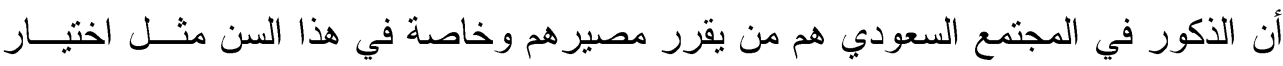

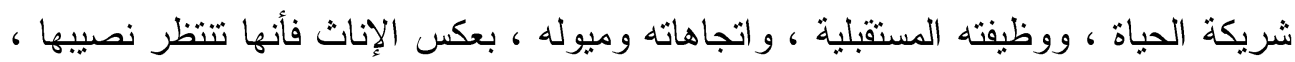

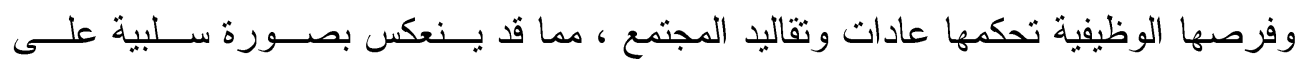

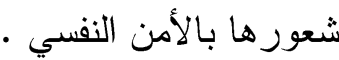

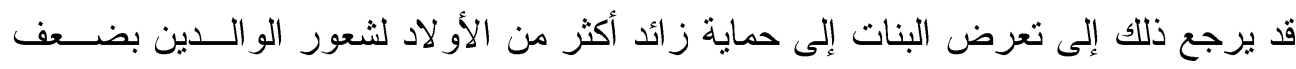

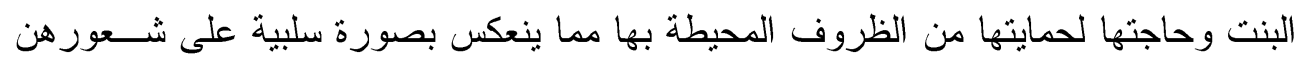
بالأمن النفس و اجن

ج - نتائج الفرض الثالث : ونصه لا توجد علاقة ارتباطيه ذات دلالة إحصائية بين درجات الأمن النفسي ودرجات جودة

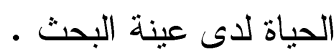

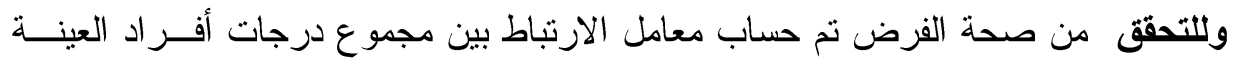
على مقياس الأمن النفسي و درجاتهم على مقياس جودة الحياة ، حيث كانت النتائج كالتالي :

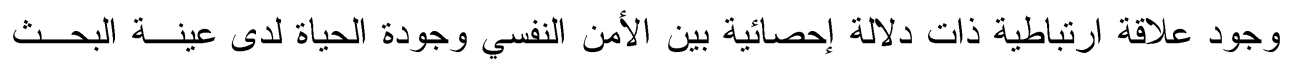

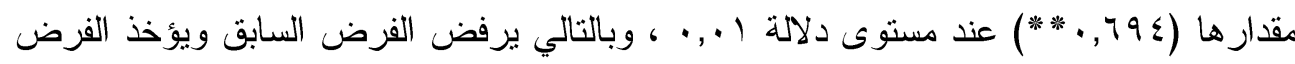

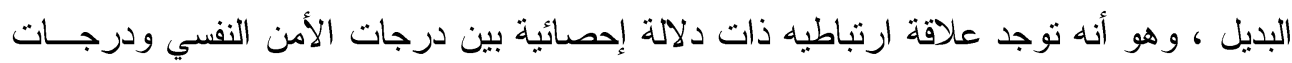

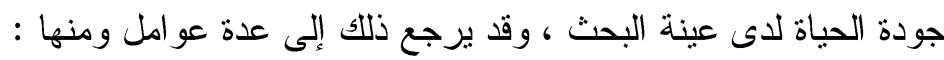

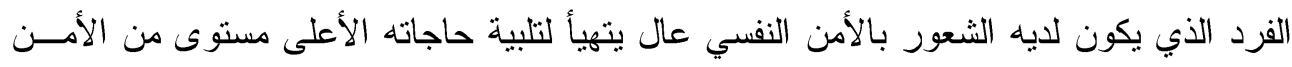

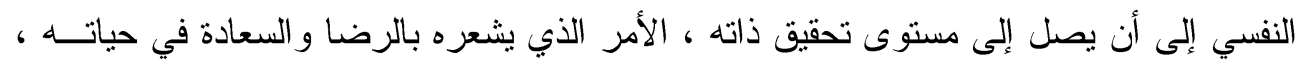

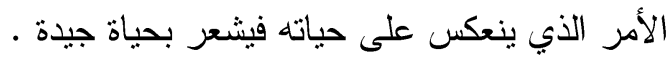


يعد الأمن النفسي مهج في إحداث التوافق والاجتماعي ، فالفرد الذي يتمتع بالشعور بالأمن النفسي

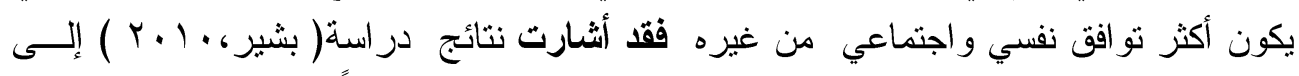

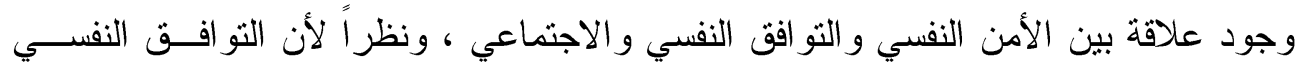

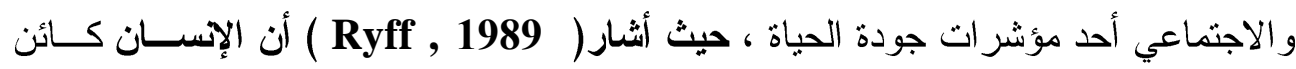

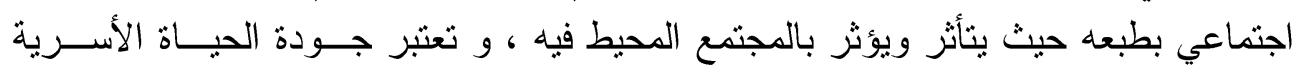

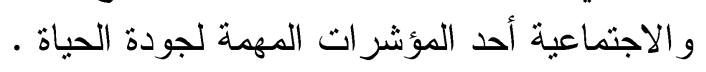

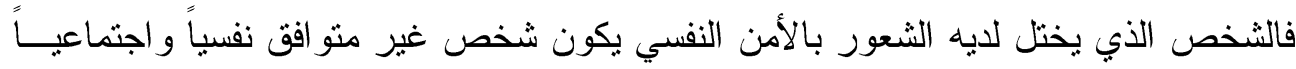

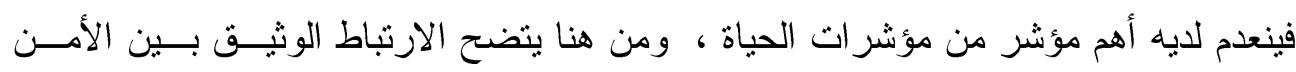

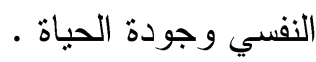

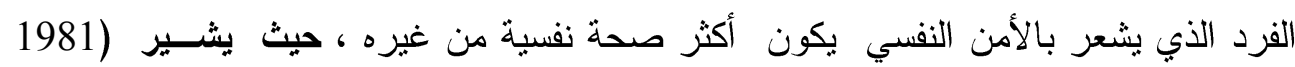
( Londervill \& main ,

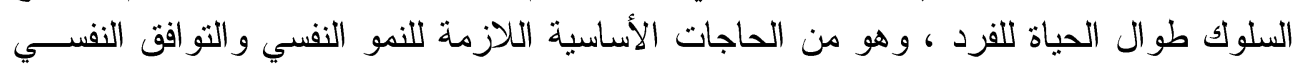

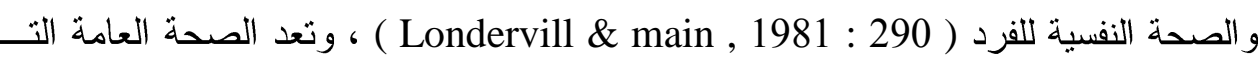
من ضمنها الصحة النفسية من أهم مؤشرات جودة الحياة ، فالشخص الذي يتمتع بصحة نفسية

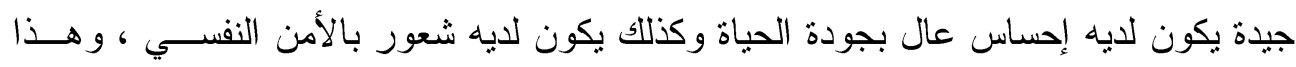

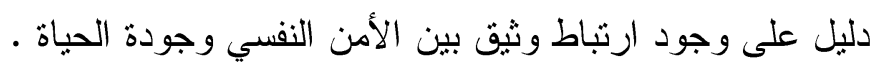

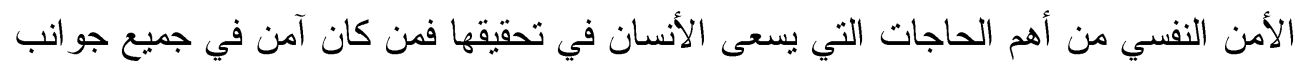

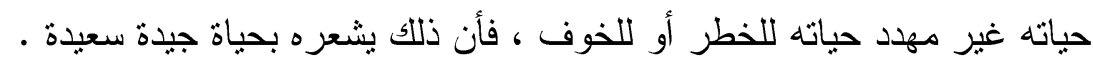

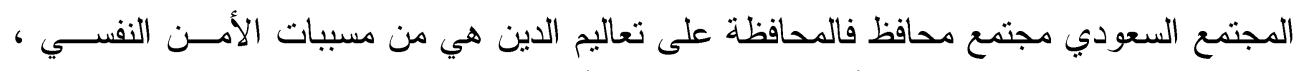

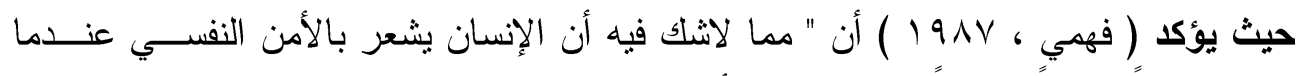

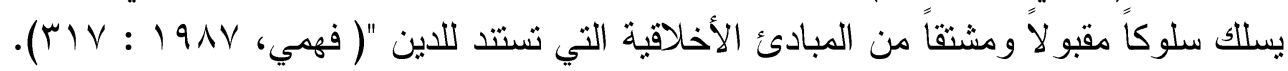

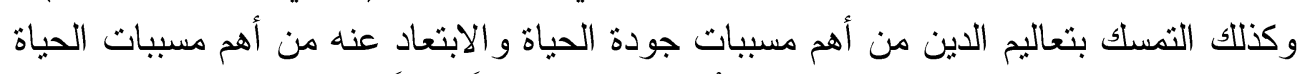

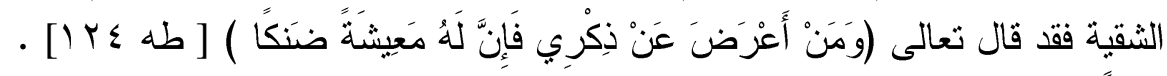

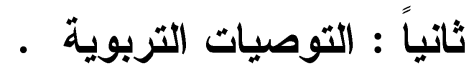

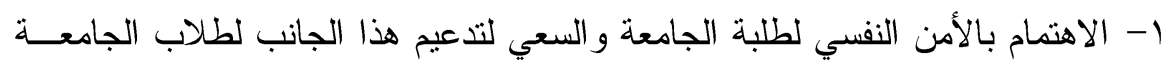

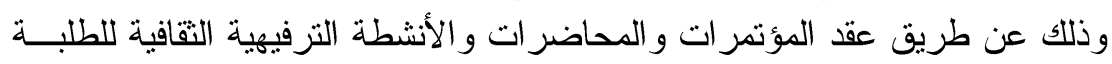

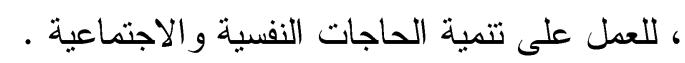

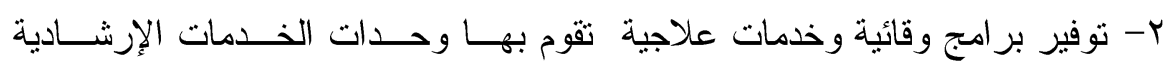

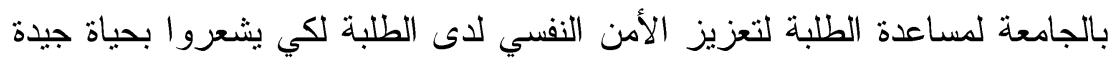

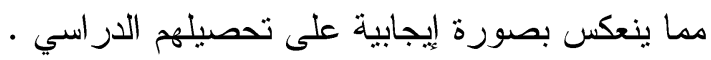


ب- تطبيق مقياس الأمن النفسي على الطلاب المتقدمين على الوظــائف و المؤسســات

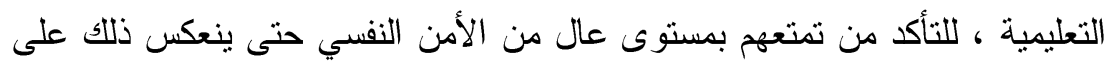

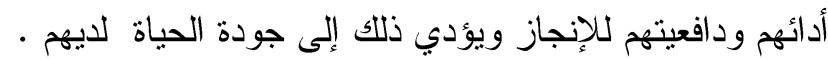

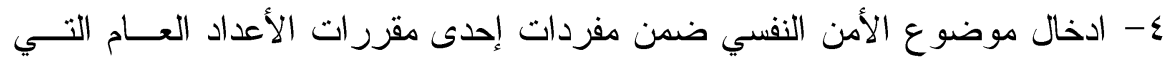

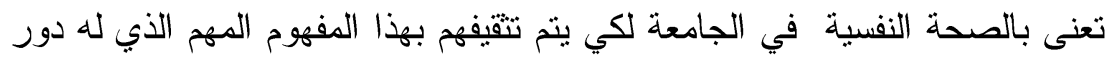
مهم في عملية التحصيل الدر اسي و اشعار هم بحياة جيدة .

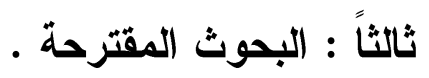
1- دراسة الأمن النفسي وعلاقته بجودة الحياة لاى الكليات الأخرى بجامعة الدمام .

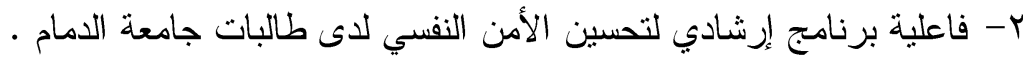

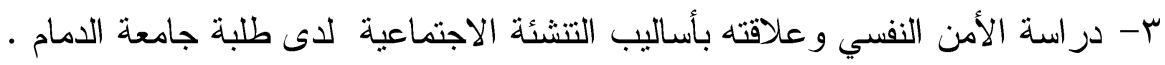

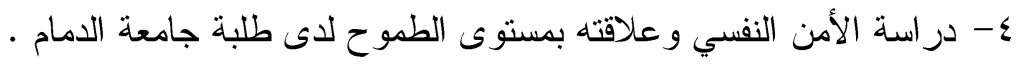

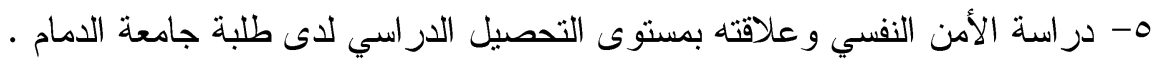




\section{قائمة المر اجع}

أولاً: المراجع العربية . ماين

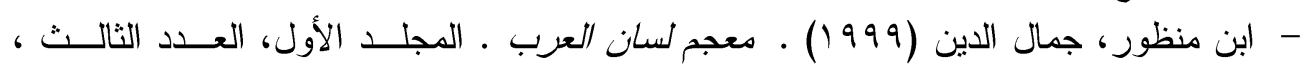

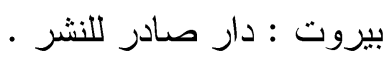

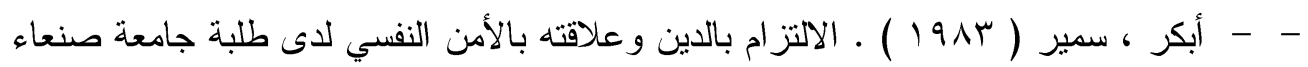

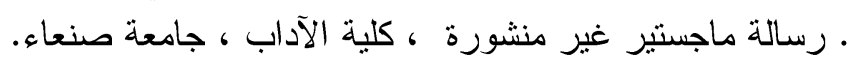

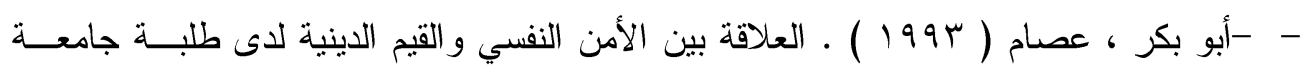

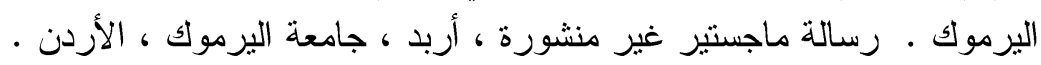

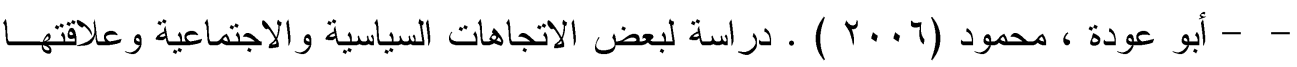

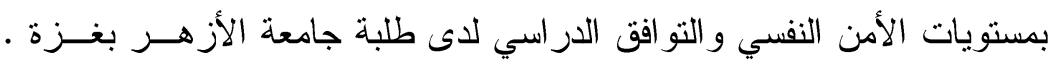

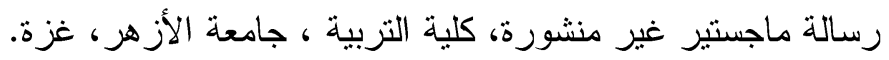

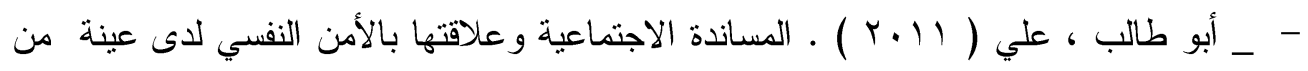

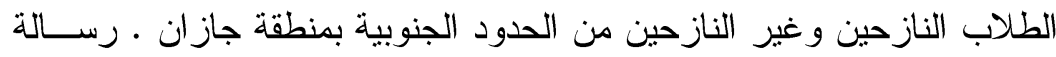

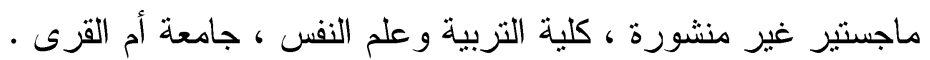

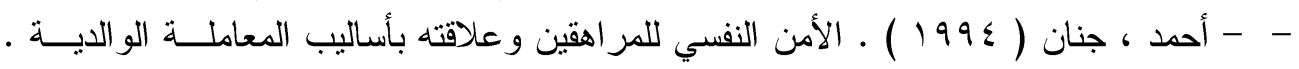

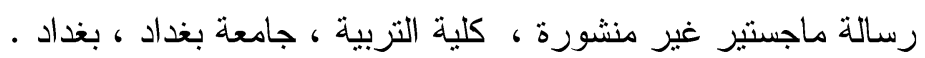

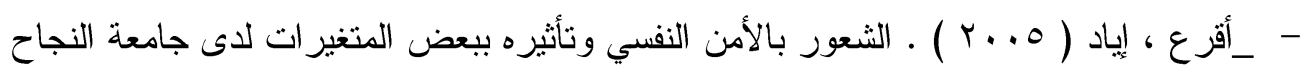

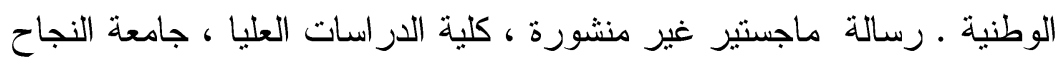

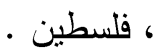

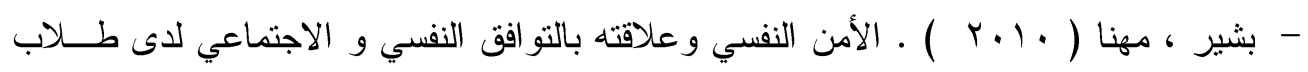

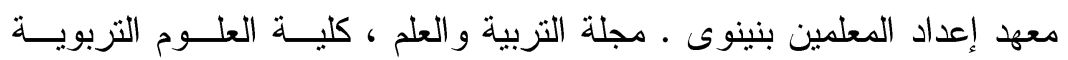

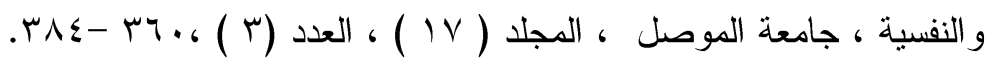

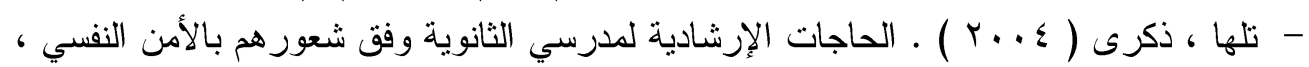

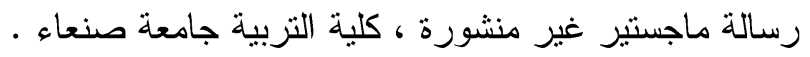

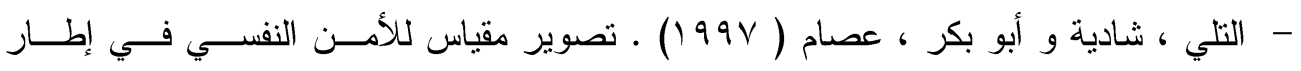

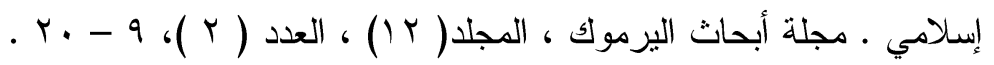

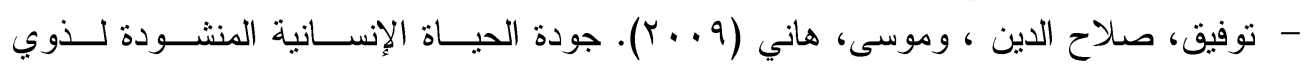

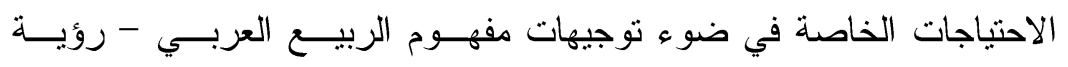

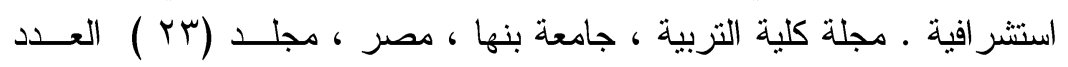

$$
\text { . VV-1 ، (9)) }
$$




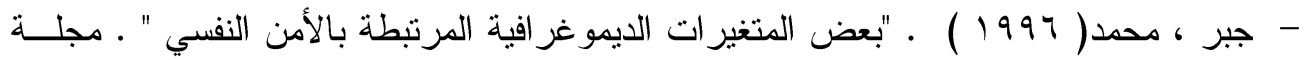

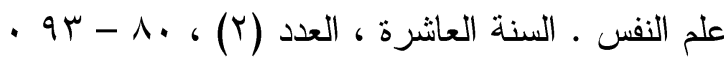

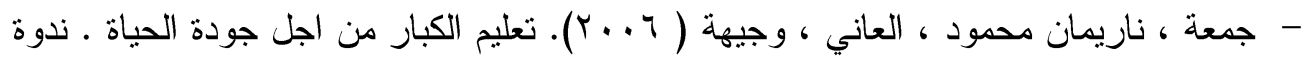

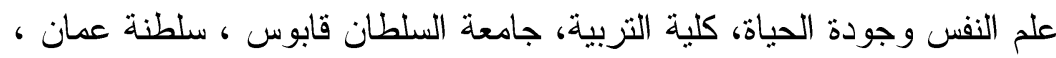

$$
\text { 19-19 } 19
$$

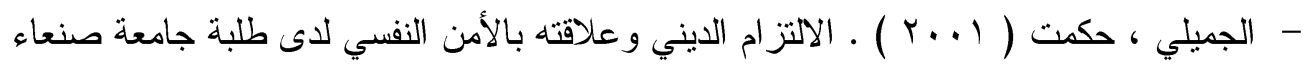

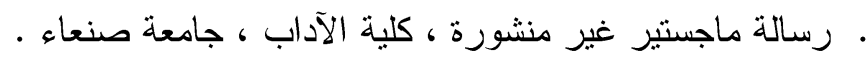

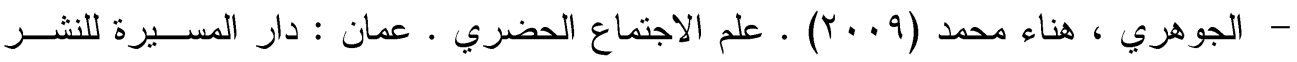

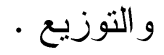

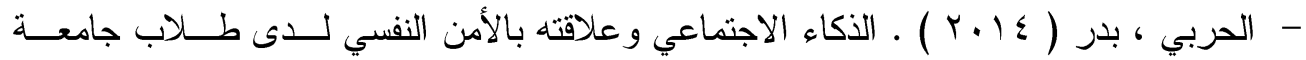

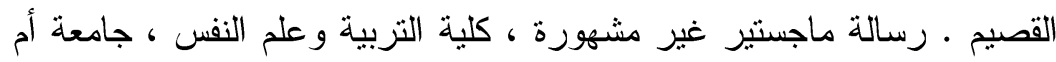

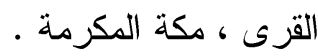

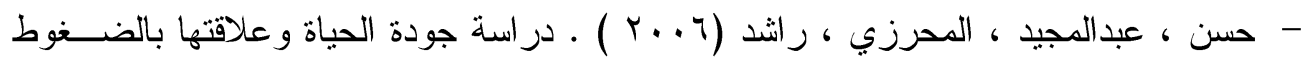

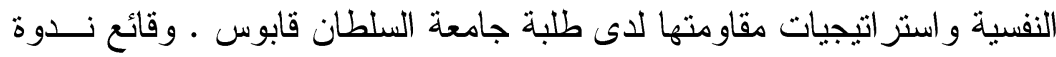

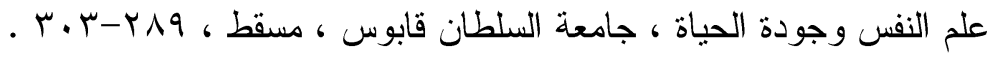

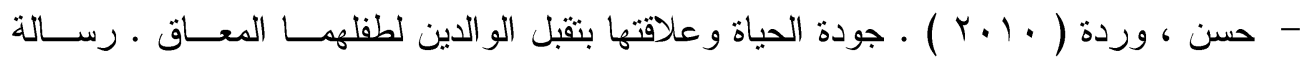

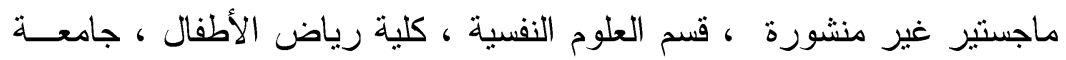
القاهرة ، القاهرة . ماهيز

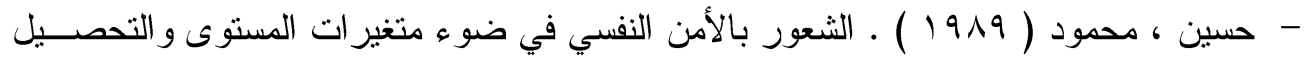

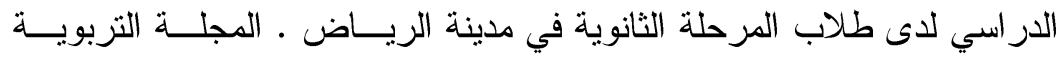

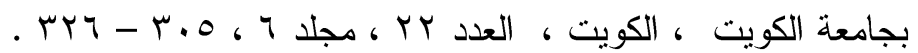

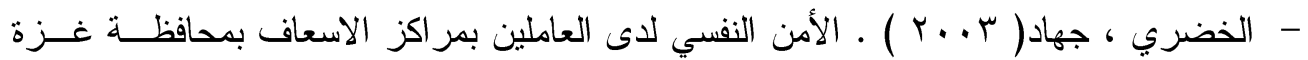

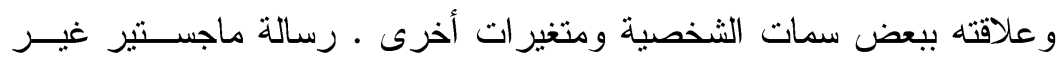

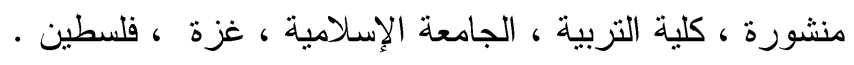

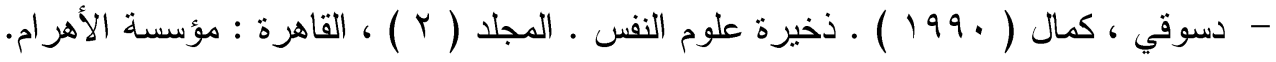

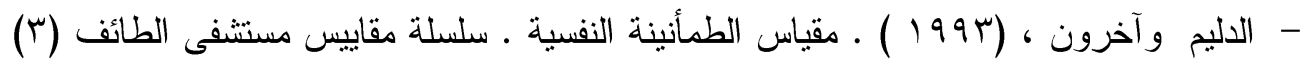

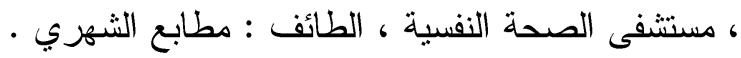

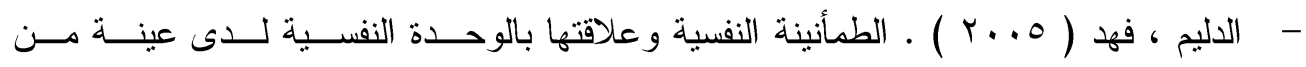

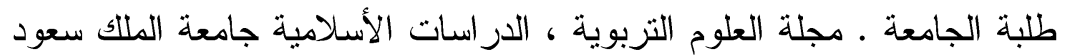

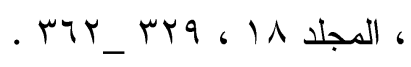

- الرازي ، محمد (71911) ـ مختار الصحاح • بيروت : مكتبة لبنان . 


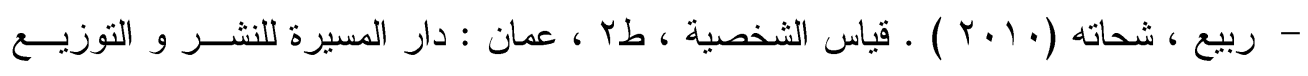

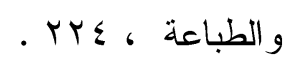

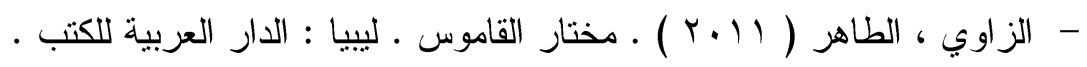

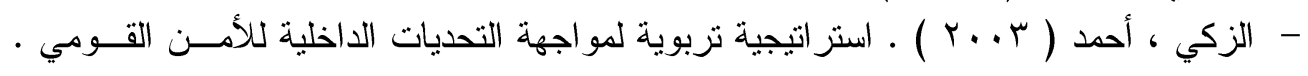

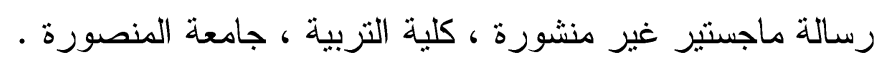

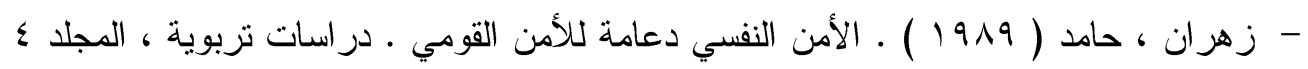

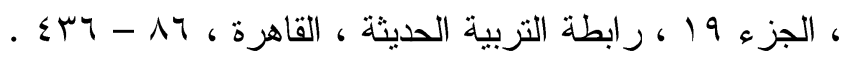

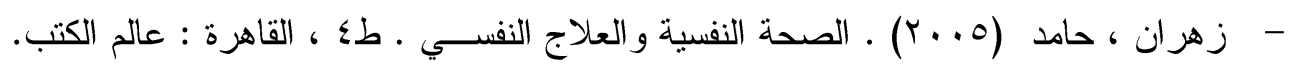

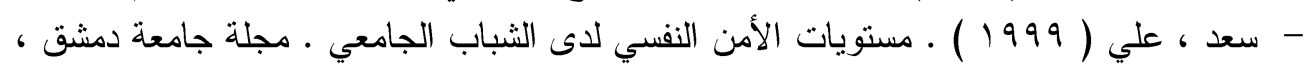

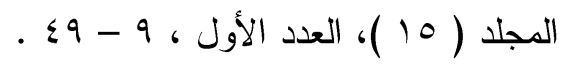

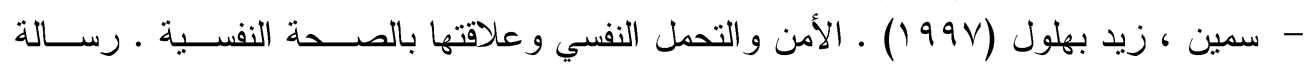

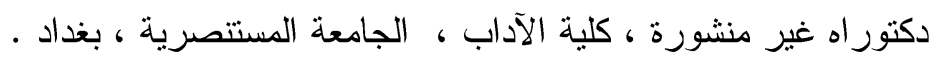

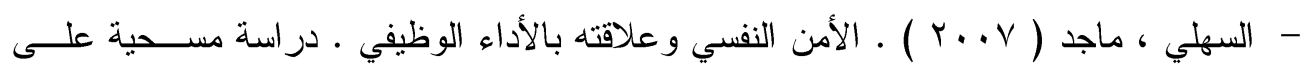

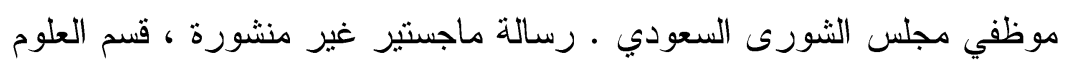

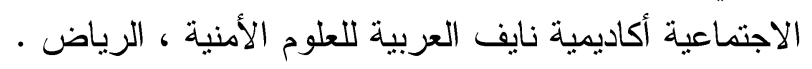

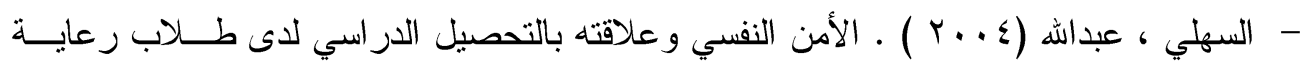

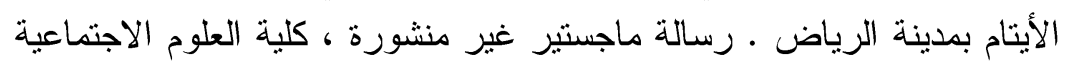

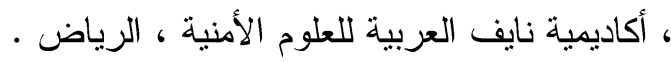

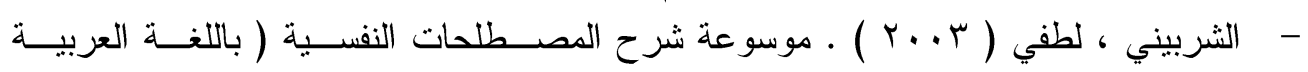

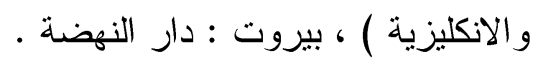

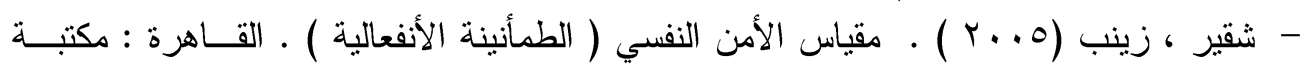

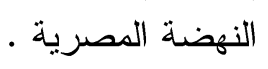

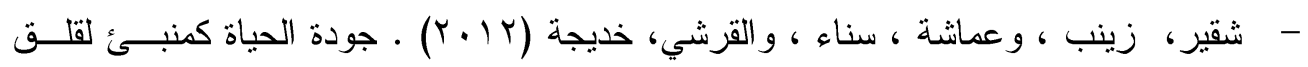

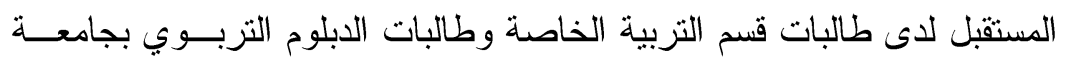

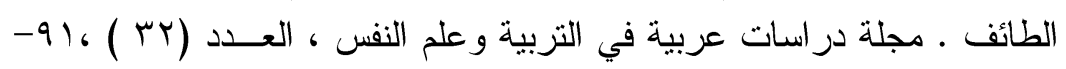
. Ir

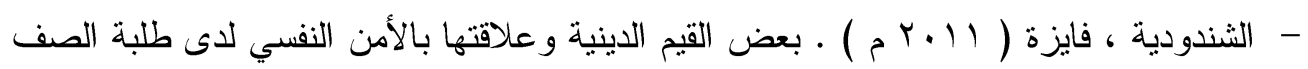

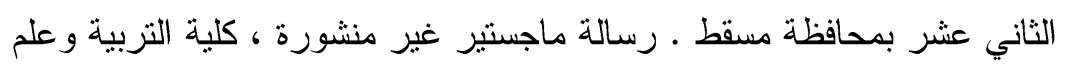

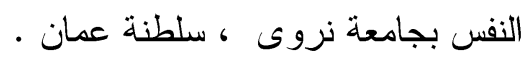




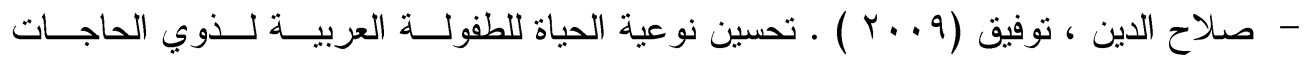

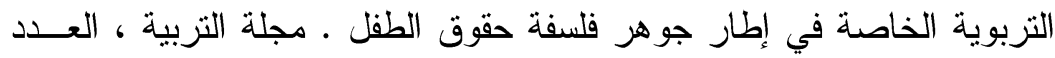

$$
\text { . rAr- Irr ، (rV) }
$$

- الصنيع ، صالح (1990 ) ) ـ دراسات في التأصيل الإسلامي لعلم النفس . طا ـالـ ـ الرياض :

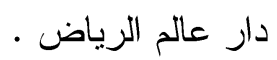

- الطويل ، هاني عبدالرحمن (1999) ـ الإدارة التعليمية دفاهيم و آفاق ـ الأردن : دار و ائــلـ

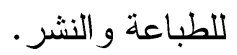

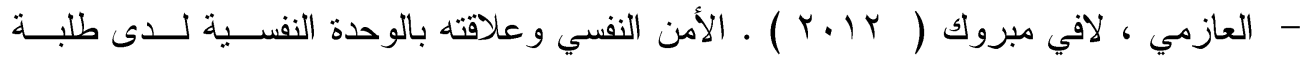

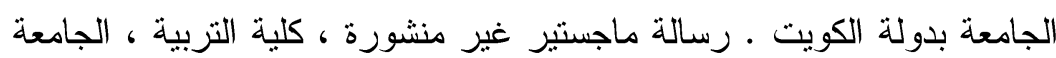

\section{الخليجية ، مملكة البحرين .}

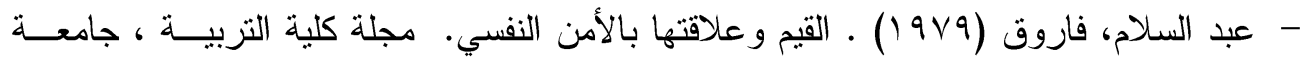

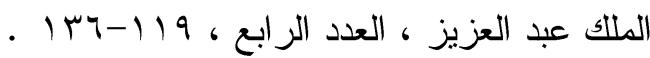

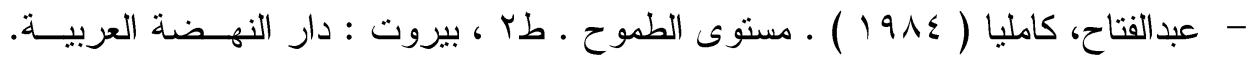

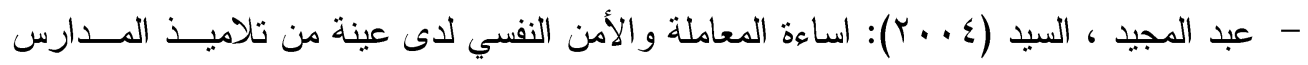

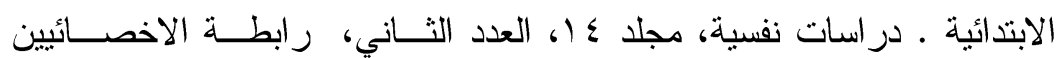

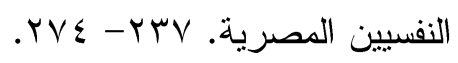

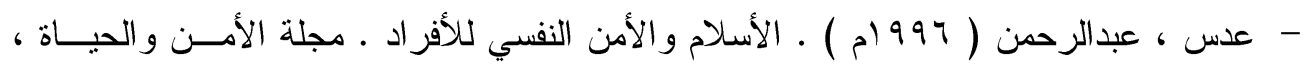

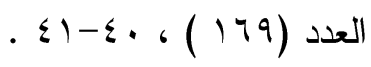

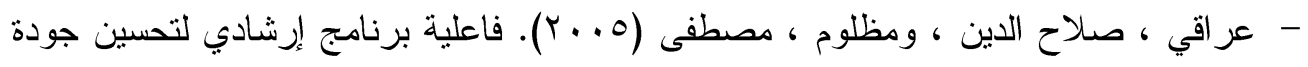

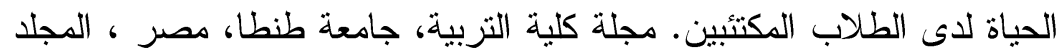

$$
\text { . }
$$

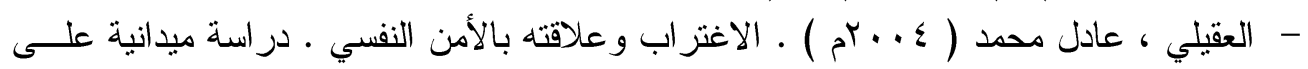

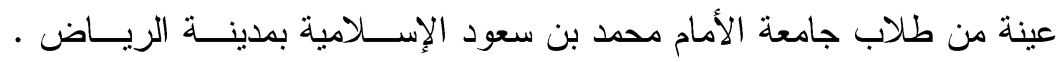

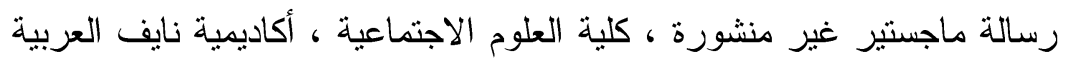

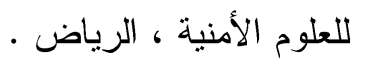

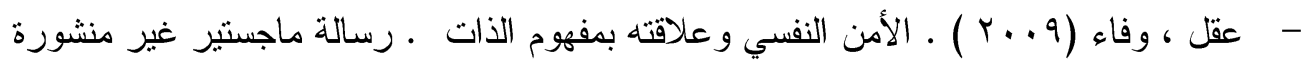

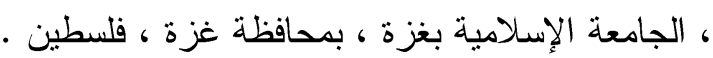

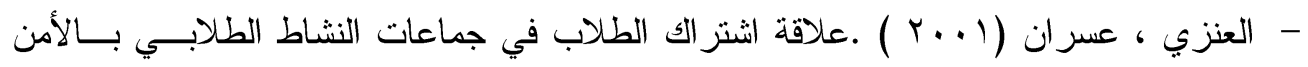



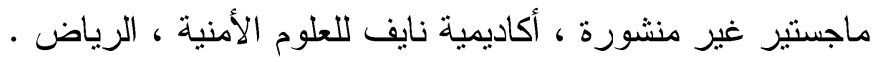


- عودة ، فاطمة ، مرسي ، كمال ( ع99 1 ) ـ الصحة النفسية في ضوء علم النفس و الاسلام .

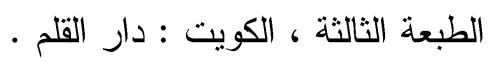

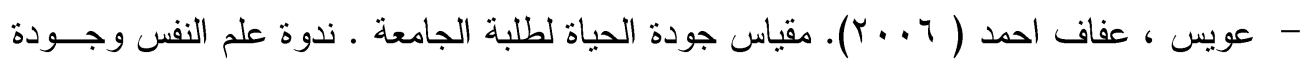

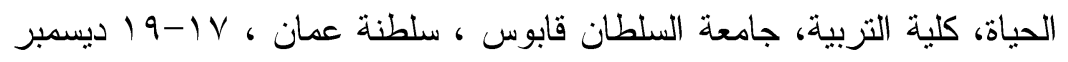

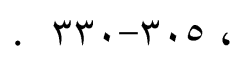

- العيسوي ، عبدالرحمن (r . . r ) ـ الإسلام و الصحة النفسية ـ ط ا ، ب بيروت ، لبنـان : دار الكتب العلمية .

- فهمي ، مصطفى (9NV ( ) . الانسان و الصحة النفسية . القاهرة : مكتبة الأنجلو المصرية.

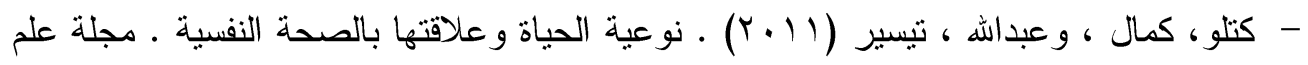

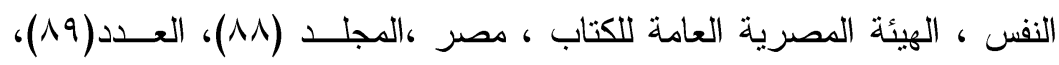

$$
\text { . } 19-7 \leqslant
$$

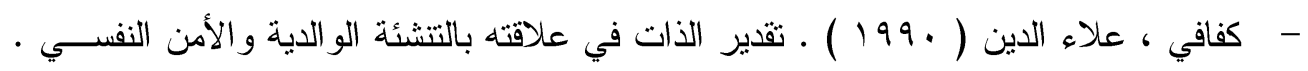

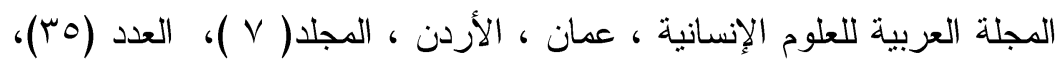

$$
\text { . rq }
$$

- كفافي ، علاء الدين (0. . ب ) ـ الصحة النفسية و الإرشاد النفسي ـ الريــاض : دار النشــر

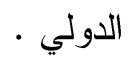

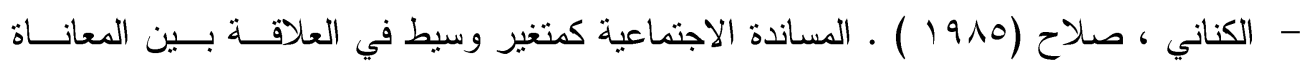

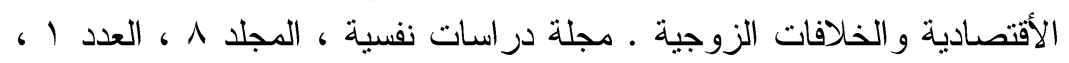

$$
\text { . }
$$

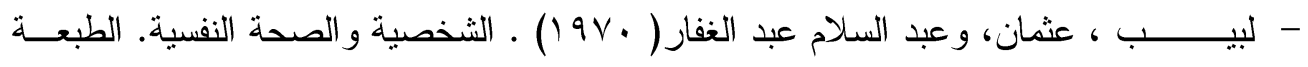

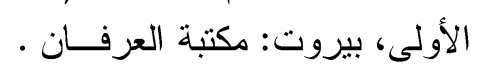

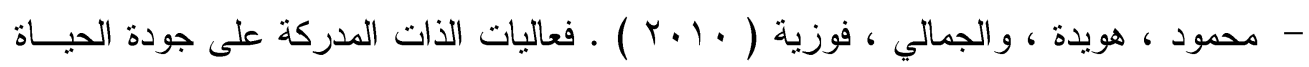

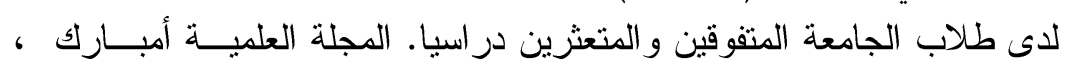

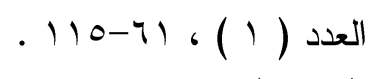

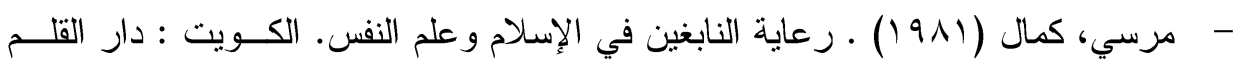

$$
\text { للنشر و التوزيع. }
$$

- مصطفى ، هبة الله (1) (1) ) ـ الأمن النفسي وعلاقته بالمعاملة الو الدية كما يدركها الأبنـاء

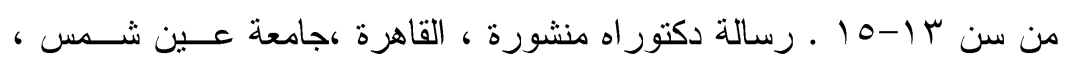

$$
\text { معهد الدراسات الطفولة. }
$$




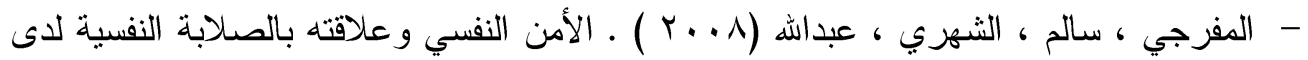

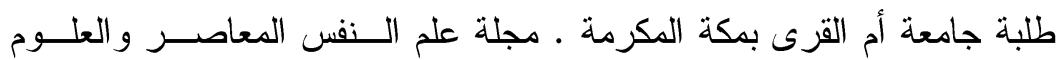

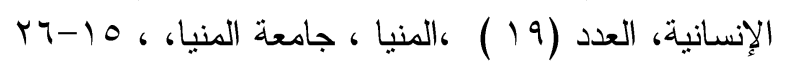

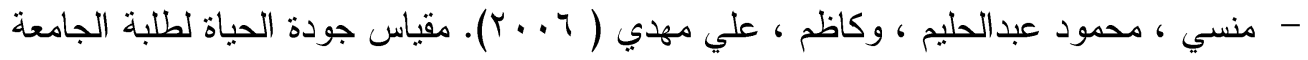

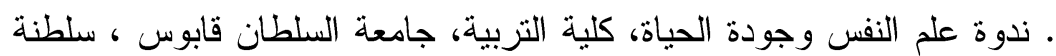

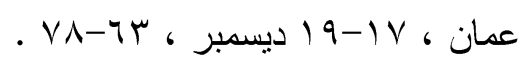

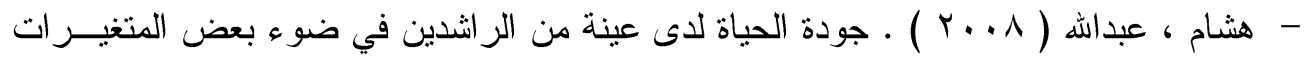

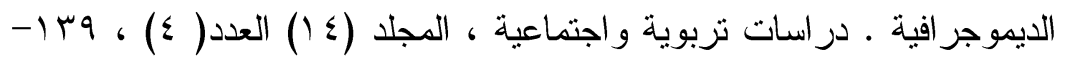

$$
.11 \text {. }
$$

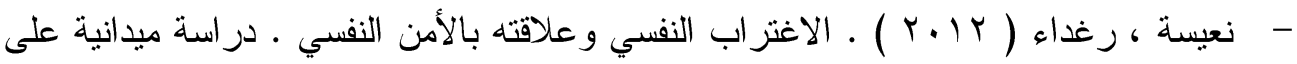

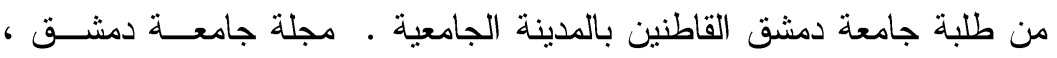

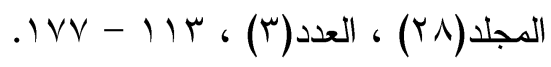

\section{ثانيًا: المراجع الأجنبية :}

- Cella , D. F \&Tulsky ,D . S ( 1993 ) . Quality of life in cancer definition , purpose , and method of measurement. Cancer lnrest ,11 (3), 327-336.

- Fatil , R .and Keddy, A . N . ( 1985 ). Study of Feeling of security in security among professional and non professional students of Gulbarg city .Indian psychological review , ( 29 ),1264 .

- From, E ( 1971 ). Escape from freedom . New York : Avon .

- Kerns, K.A , Klepac , L , Cole , A (1996) : Peer relationships and preadolescents perceptions of security in the child mother relationship. Developmental Psychology, (32) (3), 457 464.

- Litwin , M . S ( 1999 ). Measuring Quality of life after prostate cancer treatment activities. Applied and preventive Psychology, 16(2), 55-67.

- Landisville ,Susan \& Main, Mary (1981. Security of attachment, Compliance, and maternal training methods in the second year of life. Developmental Psychology, 7, (289-299)

- Maslow . A . H .( 1970 ). Motivation and personality . Harper and Row Publishers, Inc ,N . Y . 
- Roberts , et al (1996 ). Adult Attachment Security Symptoms Of Depression ,Journal personality And Social Psychology . (70), ( 2 ).

- Ryff,C.(1989). Happiness Is Everything, or Is It?: Exploration on the Meaning of Psychological Well-being. Journal of Personality and Social Psychology,57,(6),1069-1081.

- Ventegodt , S., Merrick, J., Anderson (2003). Quality of life philosophy . The brain and consciousness The scientific world journal $3,1230-1240$

- Vohra , Robert \& Sen , Arthur (1986). A study Of Rigidity And Security Among High Anxiety And Low Anxiety Groups Of Married Women . Social Science International, (2),(3743) 


\section{Abstract}

Title of the Study: (Psychological security and its relationship to quality of life on a sample of students in the College of Education in Dammam.)

Purpose of the Study: The study aims to identify the level of Psychological security for selected samples of education college students in Dammam and to highlight the relationship between their Psychological-security and quality of life. The study also aims to highlight the differences in Psychological-security based on the gender type if exist

Approach of the study: The Comparative correlation descriptive approach.

The study hypotheses : The study hypotheses is designed as follows:-

The students at the Collage of Education in Dammam have high level of the psychological level of security.

There are statistical differences, between male and female average score on the psychological security scale, indicate that the male has higher score than female.

There is a statistical relationship between the psychological security and life quality scores within selected samples.

Sample of the study: The researcher will use the comparative correlation descriptive approach on 100 students selected randomly from Collage of Education at the University of Dammam.

Tool of the study: The following tools will be used to complete this study:- Psychological security.. ( By Dulaimi and others, 2003 )

Scale of Scale of quality of life ( By Mahmud Mansi and Ali Khadim)

SPSS program will be used in in the statistical treatment of the study.

It is reached by the study of the results of the following:

1. Enjoy Dammam University students high level of psychological security, where he found that the arithmetic average of the level of psychological security to the students of the University of Dammam (218.2), and such a degree higher than the arithmetic mean of the total 
score for a measure of psychological security (150), and standard deviation equal to (26214).

2. There are statistically significant differences between the average scores of male and female differences on the security scale, where the arithmetic mean of the sample male equivalent (226.88), while the degree of the arithmetic average for females is equal to (209.52), and the degree of (v) equal to (3494) for males and females.

3 . The presence of a statistically significant correlation between the psychological level of security and the level of quality of life in a sample of students of the University of Dammam amount relationship (**0.694), when the level of significance 0.01 